EFEITO DA ROTAÇÃO DE CULTURAS NO RENDIMENTO, NA EFICIÊNCIA ENERGETICA E ECONÔMICA DO TRIGO, EM PLANTIO DIRETO

\author{
HENRIQUE PEREIRA DOS SANTOS \\ Engenheiro Agrônomo
}

Orientador: Prof. Dr. ANTONIO LUIZ FANCELLI

\begin{abstract}
Tese apresentada à Escola Superior de Agricultura "Luiz de Queiroz", da Universidade de São Paulo, para obtenção do título de Doutor em Agronomia. Área de concentração Fitotecnia.
\end{abstract}

\author{
PIRACICABA \\ Estado de São Paulo - Brasil \\ Dezembro - 1992
}


Ficha catalogréfica preparada pela Seça de Livros da Divisăo de Eiblioteca e Documentagăo - FClR/usf

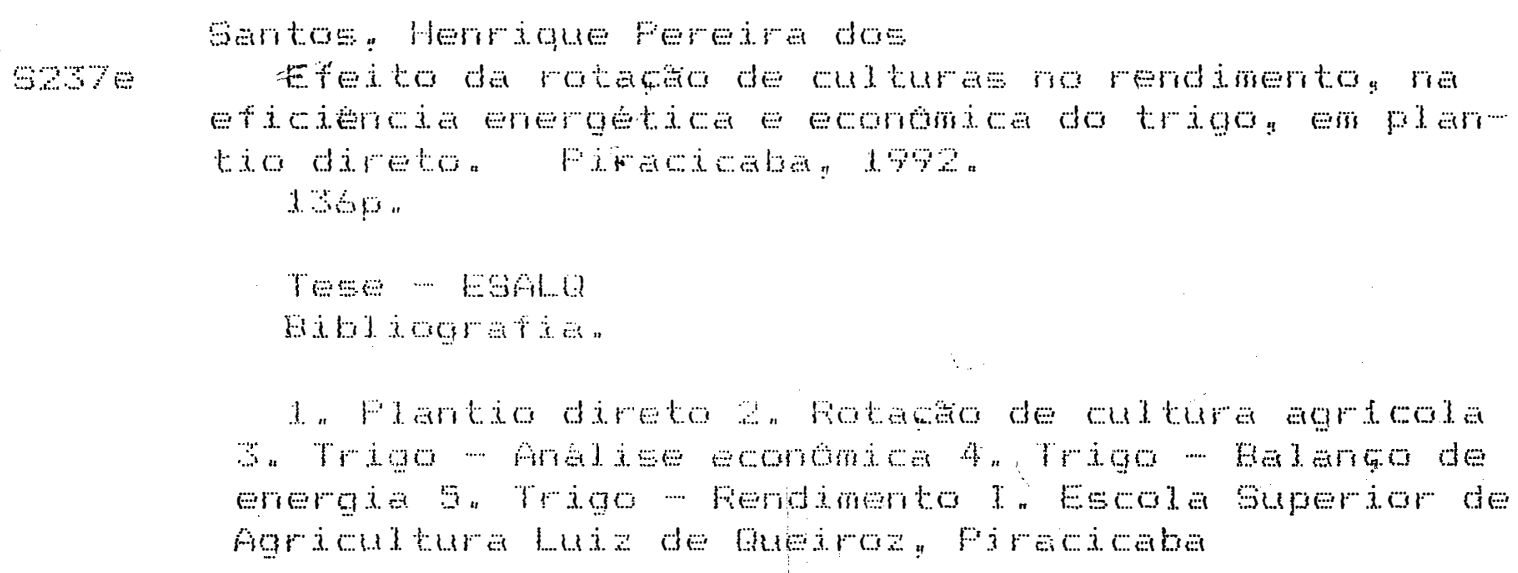


EFEITO DA ROTAÇÃO DE CULTURAS NO RENDIMENTO, NA EFICIÊNCIA ENERGETICA E ECONÔMICA DO TRIGO, EM PLANTIO DIRETO

HENRIQUE PEREIRA DOS SANTOS

Aprovada em 05/02/93

Comissão Julgadora:

Prof. Dr. Antonio Luiz Fance 11 i............ ESALQ/USP

Prof. Dr. Gil Miguel de Sousa Câmara .......... ESALQ/USP

Prof. Dr. Evaristo Marzabal Neves ........... ESALQ/USP

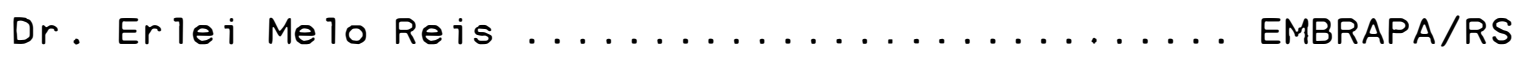

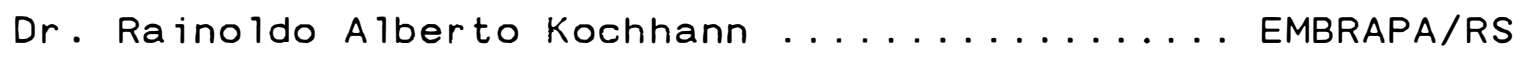

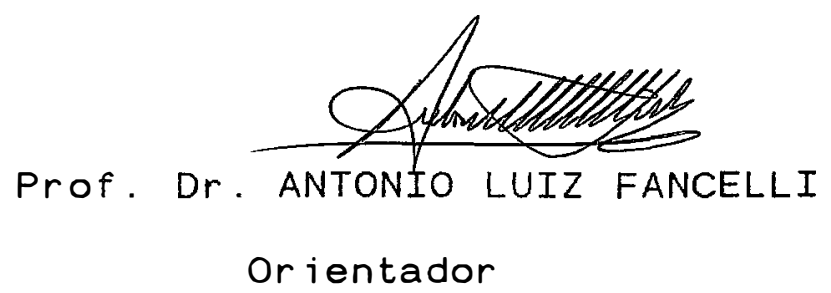


A memória de meus pais Vasco e Aracy e meu sogro Norberto. A minha sogra Cerena, meus irmãos Edi, José Ramos e Edisom e Familiares e meus cunhados Cirilo, Jorge e Familiares.

MEU RECONHECIMENTO E GRATIDÃO

A minha esposa Clarice e
às minhas filhas Alice
Cristina e Araci. pela
sua compreensão e carinho.




\section{AGRADECIMENTOS}

Á Empresa Brasileira de Pesquisa Agropecuária-EMBRAPA e ao Centro Nacional de Pesquisa de Trigo-CNPT, Dela oportunidade dada para realizar o curso de pósgraduação .

Á Escola Superior de Agricultura "Luiz de Queiroz"-ESALQ/USP, pela aceitação no curso e aos professores, pelos ensinamentos recebidos.

Ao Prof. Dr. Antonio Luiz Fancelli pela orientação e ajuda crítica na elaboração da tese.

Ao Conselho Nacional de Desenvolvimento Científico e Tecnológico-CNPq, pela bolsa de estudo oferecida durante à vigência do curso.

Á Cooperativa Agrária Mista Entre Rios Ltda., Guarapuava, PR, pelas facilidades oferecidas na condução do trabalho de pesquisa.

Ao Erlei Melo Reis e Júlio Cesar Baraneche Lhamby, pela amizade, incentivo, coleta de material e determinações de alguns dados.

Ao Anton Gora e Celso Wobeto, pela amizade e facilidades oferecidas na Cooperativa Agrária.

Ao Luiz Henrique Andia e'Prof. Dr. Evaristo Marzabal Neves, pelo auxílio e orientação nas análises econômicas.

Ao Ary Jorge Dal-Piaz, Domingos Fachi, Pedro 
Meira e Pedro Reichert, pela ajuda na condução do ensaio à nível de campo.

A Inês Fátima Mandelit. pelo auxilio na avaliação das doenças do sistema radicular do trigo.

A Regina Manto. pelas análises estatistica.

A Katia Maria de Andrade Ferraz. pela amizade e revisão das referências bibliográficas.

Ao Augusto e Selma Baier. Elias e Sandra Tornisielo. Ivo e Leane Oliveira. Levi e Mariazinha Barros. Luiz e Olinda Pereira. Nelson e Aneci Faganello e Vanderlei e Norma Xavier. pelo apoio e amizade.

A minha esposa Clarice e às mminas filhas Alice Cristina e Araci, pelos momentos de alegria. sacrificio, estima e dedicação, tornaram possível este trabalho. 
SUMÁRIO

Pägina

RESUMO

viii.

SUMMARY

$x i$

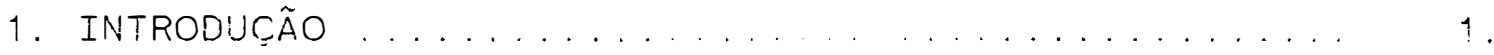

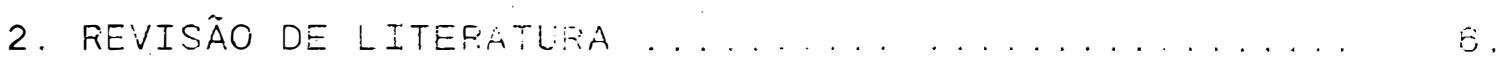

2. 1. Rotação de culturas ................. 6 .

2.1.1. Ob.jetivos de rotação de culturas ..... 8 .

2.1.2. Efeitos de rotação de culturas sobre o controle de doenças .............. 10.

2.1.3. Efeitos de rotação de culturas sobre o controle de plantas daninhas ........ 13.

2.1.4. Efeitos de rotação de culturas sobre o controle de pragas ............... 16 .

2.1.5. Efeitos de rotação de culturas sobre algumas propriedades quimicas do solo

2.1.6. Efeitos de rotação de culturas sobre as plantas .................. 19.

2.1.7. Efeitos de rotação de culturas sobre conservação do so $10 \ldots \ldots \ldots \ldots \ldots . \ldots 23$.

2.1.8. Interação entre manejo de solo e ro-

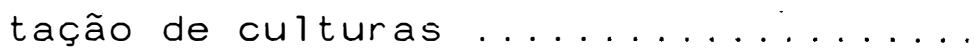

2.1.9. Interação entre clima e rotação de

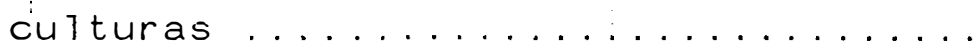

28.

2.1.10. Efeitos da rotação de culturas no rendimento de algumas plainas culti-

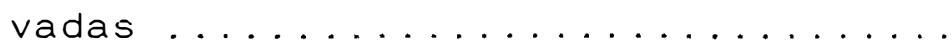

30 .

2.1.11. Efeitos da rotação de culturas na eficiência energética de sistemas de

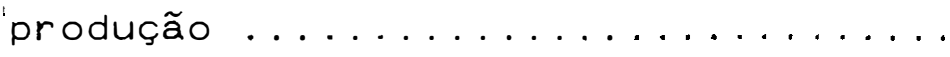

32.

2.1.12. Efeitos da rotação de culturas na eficiência econômica de sistemas de produção 
2.2. Espécies vegetais de inverno para rotação no Sul do Brasil ...................... 35 .

2.3. Sistema Plantio direto ................ 39.

3. MATERIAL E METODOS .................. 45 .

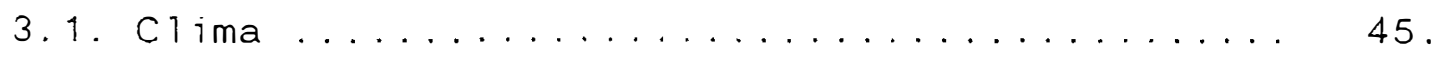

3.2. Caracteristica da área experimental ....... 46.

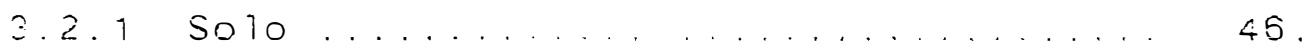

3.2.2. Parcelas experimentais ............ 46.

3.2.3. Correção da acidez do solo .......... 50.

3.2.4. Amostragem do s010 .............. 51.

3.2.5. Culturas usadas no experimento ....... 51.

3.2.5.1. Aveia ............... 51 .

3.2.5.2. Cevada ............... 52 .

3.2.5.3. Ervithaca ........... 52 .

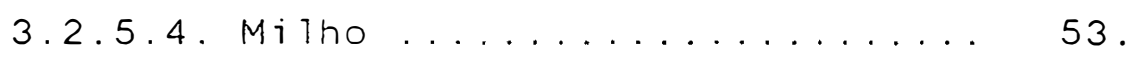

3.2 .5 .5 . Soja ................... 53 .

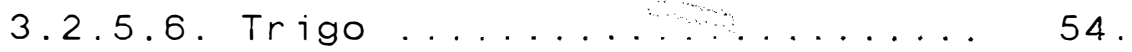

3.2.6. Adubação e tratos culturais ......... 54.

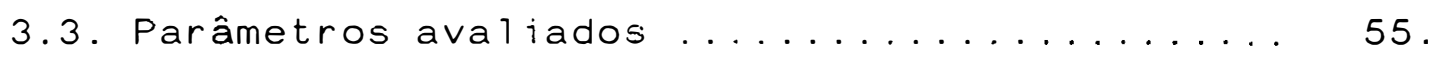

3.3.1. Rendimento de grãos de aveia, de cevada, de milho, de soja e de trigo..... 55.

3.3.2. Intensidade e doenças do sistema radicular do trigo ................ 55 .

3.3.3. Análise do balanço energético dos sistemas de rotação para trigo ......... 56.

3.3.4. Análise econòmica dos sistemas de rotação para trigo ............... 57.

3.4. Delineamento experimental ............ 57 .

4. RESULTADOS .............................. 59 .

4.1. Rendimento de grãos de aveia. de cevada. de mitho, de soja e do trigo e intensidade das doenças do sistema radicular do trigo ....... 59.

4.2. Balanço energético dos sistemas de rotação

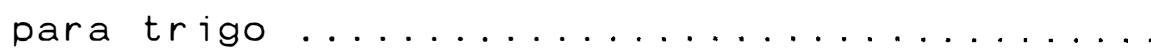


4.3. Análise econômica dos sistemas de rotação

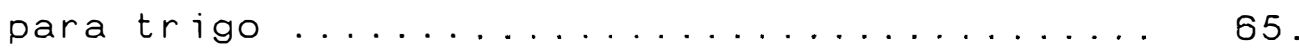

4.4. Evolução da fertilidade do solo .......... 78.

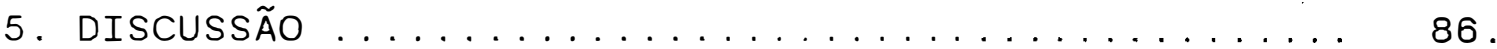

5.1. Rendimentos de grãos de mitho. de soja e de trigo e intensidade de doenças do sistema

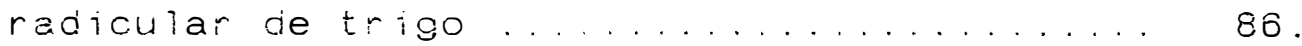

5.2. Balanço energético dos sistemas de rotação

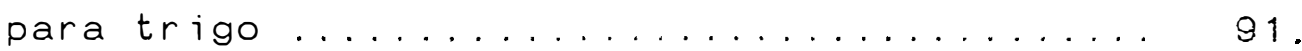

5.3. Anátise econômica dos sistema de rotação

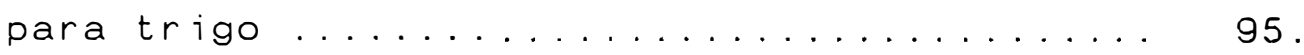

5.4. Evolução da fertilidade do solo ......... 98.

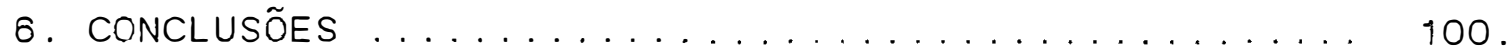

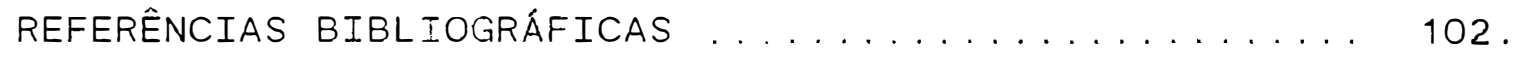

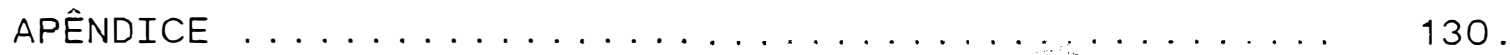


$\vee i j i$

\title{
EFEITO DA ROTAÇÃO DE CULTURAS NO RENDIMENTO, NA EFICIÊNCIA ENERGETICA E ECONÔMICA DO TRIGO, EM PLANTIO DIRETO
}

\author{
Autor: Henrique Pereira dos Santos \\ Orientador: Prof. Dr. Antonio Luiz Fancel1i
}

RESUMO

Foram avaliados durante dois anos. na Cooperativa Agrária Mista Entre Rios Ltda., Guarapuava, PR, Brasil: em solo classificado como Associação Bruno Álico + Cambissolo, os efeitos de sistemas de rotação no rendimento de grãos de milho, de soja e de trigo, bem como a intensidade de doenças do sistema radicular de trigo. Além disso, foram estimados o balanço energético, a análise econômica e a evolução da fertilidade do solo, nos sistemas de produção para trigo.

O delineamento experimental usado foi o de blocos ao acaso, com quatro repetições, em parcelas medindo $10 \mathrm{~m}$ de comprimento e $6 \mathrm{~m}$ de largura, ponfazendo uma área total de $60 \mathrm{~m}^{2}$. Os tratamentos foram constituidos de quatro sistemas de rotação para trigo: 1) monocultura; 2) rotação, com um inverno sem trigo; 3 ) rotação, com dois invernos sem trigo; 4) rotação, com três invernos sem trigo. Todas as culturas empregadas, tanto de inverno como as de verão, foram estabelecidas em plantio direto. 
Pela análise dos resultados não foram verificadas diferenças entre os tratamentos para os rendimentos de grãos de milho e de soja. após diferentes sistemas de rotação de culturas. A intensidade de doenças do sistema radicular de trigo. de um modo geral. foi maior na monocuitura. do que en comper ağa àos demals tratamentos. O trigo. no ano de 1990. apresentou rendimerios de grãos menor na monocultura. do que em relação aos demais tratamentos. O sistema plantio direto permitiu que. tanto as culturas de inverno como as de verão. fossem estabelecidas em suas melhores épocas de semeadura.

Relativo ao balanço energético. o trigo no ano de 1990. mostrou menor indice de produtividade cultural. na monocultura. do que em comparação aos demais tratamentos. Entre as gramineas de inverno. os indices de produtividade cultural. indicaram que para cada unidade de Mcal (Kcal $x$ 1.000) investida nos sistemas de rotação. o maior retorno em kg de grãos foi obtido para cultura de trigo. principalmente em função dos sistemas utilizados e não do aumento da oferta de calorias.

Considerando os quatro sistemas de rotação para trigo. esta gramínea. em rotação. apresentou receitas (bruta e líquida). superior á monocultura. no ano de 1990. Assim. o trigo em rotação foi mais atrativo economicamente. do que quando cultivado em monocultura.

De um modo geral. os tratamentos com aveia e 
com cevada. mostraram menores receitas (bruta e liquida). em relação aos sistemas de rotação com trigo. O melhor resultado econômico foi obtido com o trigo. do que com à aveia e com à cevada. devido ao maior rendimento cultural relativo e melhor preço de venda no período analisado.

Com relação à fertilidade do solo. não for am registradas modificações substanciais nas propriedades químicas do mesmo, avaliadas na camada aráve1, em função dos sistemas de rotação de culturas. Analisando-se estas propriedades, após 29 meses de cultivos em plantio direto, verificaram-se que os valores de $\mathrm{pH}$. de Ca + Mg trocáveis, de matéria orgânica, de $P$ extraível e de $K$ trocável. diminuiram de superficie $(0-5 \mathrm{~cm})$ para camadas mais profundas do solo (15-20 cm), enquanto que para o Al trocável ocorreu o contrário. 
EFFECT OF CROPS ROTATIONS SYSTEMS ON YIELD, ON ENERGETIC EFFICIENCE AND ECONOMIC OF WHEAT, UNDER NO-TILLAGE

\author{
Author: Henrique Pereira dos Santos \\ Adviser: Prof. Dr. Antonio Luiz Fancel1i
}

SUMMARY

In a two years period, the effects of some crops rotations systems on yield of corn, soybean and wheat and on root rot deseases intensity of wheat were assessed. The study was performed in the soil "Associação Bruno Álico + Cambissolo" at the Cooperativa Agrária Mista Entre Rios Ltda., in Guarapuava, PR, Brazi1. The eriergetic balance, economic analysis and evolution of some soil chemical properties on the production systems to wheat were also est imated.

A complete randomized block design with four replicates and plots with $60 \mathrm{~m}^{2}$ were used. Four rotation systems for wheat were studied: 1) monoculture; 2) rotation of one winter without wheat: 3) rotation of two winters without wheat: 4) and rotation of three winters whithout wheat. Both winter and summer crops were seeded under not i 1 lage.

Both corn and soybean cropping systems showed no significant differences in grain yield. Root disease 
intensity of wheat was higher under monoculture and lower under rotation. Wheat cropped during the 1990 growing season, under monoculture yielded less than under rotation. The notillage systems permitted seeding of winter and summer crops at optimal time of the season.

Wheat in the 1990 growing season under monoculture showed lower energetic balance than under rotation. Among the tested small grains the cultural productivity index indicated that for each Mcal unit invested in the production system, the greatest return in kg of grain was obtained for wheat. mainly as function of the tested rotational systems. instead of the increasing calories input.

In 1990. considering the four cropping systems for wheat, the rotation system was more attractive presenting higher net return when compared with wheat continuous. The cropping systems for oat and for barley showed low net return relatively to the wheat system. due to the high wheat yield and prices during that period.

No significant changes were observed on the chemical properties in the arable layer due to the crop rotations tested. For the period studied a reduction in the value of $\mathrm{pH}$ as well as in the contents of exchangeable $\mathrm{Ca}+$ $M g$, organic matter. extractable $P$ and exchangeable $K$ of soil from the surface $(0-5 \mathrm{~cm})$ to deeper layers $(15-20 \mathrm{~cm})$ was observed. The opposite occurred with the values of exchangeable Al. 


\section{INTRODUÇÃO}

(O trigo é uma planta pertecente a familia das Gramíneas e ao gênero Triticum. A espécie cultivada no Brasil é a Triticum aestivum L. O grão deste cereal produzido no país é utilizado, principalmente, para a alimentação humana. Além disso, parte do produto consumido é proveniente de outros países, objetivando complementar a demanda existente no Brasil.

Os estados mais importantes, na produção desse cereal são: Rio Grande do Sul, Santa Catarina e Paraná, perfazendo cerca de $90 \%$ da área ocupada com esta espécie.

No Sul do País (ao Sul do paralelo $24^{\circ} \mathrm{S}$ ), o clima caracteriza-se pela instabilidade, principalmente em relação à precipitação pluvial e à temperatura. No inverno ocorre excesso hídrico, durante o período de desenvolvimento do trigo. A ocorrência de chuvas frequentes durante o florescimento, aliada à alta temperatura (18 a $\left.20^{\circ} \mathrm{C}\right)$, contribui para o ataque severo de doenças. Tal fato constitui-se na principal causa da instabilidade da produção de grãos de trigo.

Atualmente, o trigo ocupa menor área do que a soja, devido à necessidade de rotação de culturas de inverno, 
visando o controle de doenças da parte aérea e das raízes.

As doenças da parte aérea do trigo representadas por manchas foliares e mancha da gluma, podem ser reduzidas pelo uso de sementes sadias, pela rotação de culturas, pela aplicação de fungicidas e pela resistência genética. Todavia, para as doenças do sistema radicular, o uso de fungicidas, no solo, tem-se mostrado inviável economicamente. No entanto, pelo pousio de inverno ou pela prática da rotação com culturas não suscetíveis ao mal-do-pé (Gaeumannomyces graminis var. tritici) e à podridão comum (Bipolaris sorokiniana), tem-se conseguido diminuir o nível de ocorrência dessas doenças.

Assim, além do relevante benefício mencionado, a rotação de culturas melhora igualmente as características físicas, químicas e biológicas do solo, gerando condiçós satisfatórias de desenvolvimento às culturas. Por sua vez, plantas bem desenvolvidas, geralmente, resistem melhor às condiçðes climáticas adversas e ao ataque de doenças e de pragas.

Deve ser levado em consideraçăo que, nesta região, vêm sendo estudados sistemas de cultivo para trigo e para cevada, sob preparo convencional de solo. Desta forma, pouco se sabe a respeito das interaçós entre rotação de culturas com métodos de preparo do solo, e, praticamente, não existem, no país, estudos detalhados com sistemas de cultivo em plantio direto. 
Por sua vez, o trigo em plantio direto, tem apresentado boas perspectivas de cultivo, tanto à nível de pesquisa como em algumas lavouras, principalmente, na região Sul do País.

Neste sistema, os resíduos vegetais das diversas espécies integrantes do programa de rotação ou sucessão de culturas permanecem na superfície do solo, como cobertura morta, contribuindo significativamente para o controle da erosão. Deste modo, o resíduo cultural é decompostomais lentamente, o que determina uma proteção mais prolongada ao solo. Por isso, espécies com relação C/N mais elevada devem ser introduzidas no sistema através, de um esquema de rotação de culturas devidamente planejados.

Por outro lado, tem sido observado que isto pode favorecer a sobrevivência e a multiplicação dos parasitas do sistema radicular (mal-do-pé e podridão comum), das manchas foliares (Helmintosporiose-Bipolaris sorokiniana e. mancha salpicada da folha-Septoria tritici) e da mancha da gluma (Septoria nodorum) de trigo, as quais têm se evidenciado com maior intensidade sob monocultura. Desta feita, o emprego da rotação de culturas, sob o ponto de vista sanitário, mostra-se imprescindivel nessistema plantio direto.

Além disso, assume importância crescente o conhecimento do desempenho de programas de rotação de culturas sob ponto de vista energético e econômico. Assim, 
tem sido observado que, toda vez que acrescenta-se novos fatores para modernizar a agricultura, intensifica-se o uso de energia. Contudo, estes fator'es implicam no incremento de dispêndio de energia, que por sua vez, influi nos fluxos e nas taxas de retorno do capital investido. Por isso, objetiva-se o desenvolvimento de sistemas de produção para trigo que apresentem baixo consumo de energia e elevado retorno econômico.

Assim sendo, o presente trabalho apresenta os seguintes objetivos:

1) Avaliar o efeito de sistemas de rotação de culturas sobre o rendimento de grãos de trigo e sobre a intensidade de doenças radiculares, em plantio direto;

2) comparar o comportamento de culturas alternativas de inverno, com o trigo, em plantio direto;

3) verificar o efeito das culturas de inverno (aveia, cevada, ervilhaca, e trigo) sobre o rendimento de grãos do milho e da soja, cultivadas em sucessão, no sistema plantio direto;

4) avaliar os efeitos dos programas de rotaçăo e de sucessão culturas propostos, em plantio direto, na fertilidade do solo;

5) Estabelecer o balanço energético dos sistemas de produção estudados, visando a determinação do nível de eficiência de conversão da energia na produção de grãos e, 
6) Avaliar sob o ponto de vista econômico o desempenho dos diferentes sistemas de produção estipulados. 


\section{REVISÃO DE LITERATURA}

\subsection{Rotação de culturas}

A rotação de oulturas é uma prática agrícola recomendada desde há muito tempo. A observação e a experiência antiga mostraram aos agricultores a necessidade de variar as culturas em um mesmo campo, através da prática da rotação, a qual se constitui na alternância regular de diferentes culturas em uma mesma área. Essa troca deve ser efetuada de acordo com um planejamento adequado, no qual devem ser considerados diversos fatores, entre eles a cultura predominante da regiăo, em torno da qual será programada a rotação, além dos fatores de ambiente que influirão nas culturas escolhidas para sucessão (ROSA, 1980 e SANTOS, 1990).

$$
\text { Assim, segundo DERPSCH (1985), fotaçăg de }
$$
culturas pode ser conceituada como sendo a seqüência ordenada de diferentes culturas, no tempo e no espaço, desce que a mésma espécie não seja implantada no local considerado dentro do período de dois anos. Por outro lado, sucessãg de culturas refere-se à alternância pré-estabelecida de culturas, dentro do mesmo ano agrícola. Por isso que o emprego da cultura de 
trigo após à soja, ao longo dos anos, é considerada como sendö a prática agrícola denominada de sucessão de culturas e não rotação de culturas. Ainda, a semeadura repetida da mesma espécie vegetal, no mesmo lugar e em todos os anos, constitui-se na prática da monocultura agrícola.

Desta maneira, a rotação de culturas permite várias opçơes de uso, tais como:

1) culturas alternadas de espécies com habilidade diferenciada no aproveitamento de nutrientes do solo ou com sistema radicular, alcançando profundidades variadas ;

2) culturas intercaladas de espécies suscetíveis a certas doenças ou práas, com outras resistentes;

3) culturas alternados de espécies que apresentam efeitos negativos ou positivos de uma cultura sobre a subseqUente. (A origem desses efeitos pode ser devido a substâncias tóxicas, nutrientes fornecidos e incremento de matéria orgânica: fenômeno denominado de alelopatia);

4) cultivos alternados de espécies que tendem a exaurir o soló com culturas que contribuam para melhorar a fertilidade do mesmo e,

5) intercalar espécies que utilizam a mesma mão-de-obra, equipamentos agrícolas e instalaçð̃es, em estaçơes diferentes. 
2.1.1. Objetivos da rotação de culturas

A rotação de culturas apresenta os seguintes objetivos: a) diversificação de renda; b) melhoria do aproveitamento do parque de máquinas e da mão-de-obra na propriedade; c) contribuição para a manutenção e melhoria da fertilidade do solo; d) diminuição significativa da incidência de doenças, de plantas daninhas e de pragas; e) redução das perdas do solo pelo controle da erosão e f) aumento e estabilidade da produtividade das espécies (ROSA, 1980 ; SANTOS et al., 1987d; TOMAZINI, 1987; VIEGAS \& MACHADO, 1990).

A diversificação de culturas de inverno, como de verão, não se resume apenas em necessidade agronômica, mas sobretudo, em uma necessidade social e econômica, principalmente, para os pequenos e médios agricultores. Por outro lado, a monocultura de inverno ou de verão, implica em elevado risco para a produção e renda da propriedade.

A utilização de diversas culturas na exploração rural permite ao agricultor usar os equipamentos de semeadura e de colheita, durante um maior número de horas por ano, o que reduzirá o custo do capital imobilizado.

o uso de um sistema de rotação eficiente permite, por outro lado, escolher os periodos de preparo do solo, de semeadura, de tratos culturais e de colheita, de 
modo a determinar uma melhor distribuição das exigências de mão-de-obra, em comparação à monocultura.

A rotação de culturas apresenta papel

importante na reciclagem de nutrientes, uma vez que, de acordo com MENGEL \& KIRKBY (1987), as espécies vegetais diferem entre si, com referência à quantidade de resíduos fornecidos, à eficiência de absorção de íons e à exploração de diferentes profundidades do solo.

Da mesma forma, a rotação de culturas constitui-se numa prática efetiva de prevenção de doenças e altas densidades de espécies de plantas daninhas e elevada incidência de pragas.

Ainda, a utilização de sistemas de rotaçăo, visando intercalar culturas que se complementem, objetivando à redução das perdas de solo pela erosão, é de suma importância.

A rotação de culturas, fundamentada em espécies, tanto de inverno como de verão, tem contríbuido para aumentar a estabilidade e os rendimentos das culturas principalmente do trigo (SELMAN, 1975; REIS et al., 1983; PEREIRA et al., 1984; PREW et al., 1986; SANTOS et al., 1988, 1990a e 1990b) e da soja (GAUDÊNCIO et al., 1986 e SANTOS \& REIS, 1991). Esta prática é indispensável para o melhor desempenho e produtividade dos cereais de inverno, em regiơs de clima adverso (REIS et al., 1988), como na região brasileira localizada ao sul do paralelo $24^{\circ} \mathrm{S}$. 
2.1.2. Efeitos de rotação de culturas sobre o controle de doenças

Os agentes causais das doenças de maior importância para as culturas, podem ser classificados em parasitas biotróficos e necrotróficos (FEDERATION OF BRITISH PLANT PATHOLOGIST, 1973). Os parasitas biotróficos são aqueles que extraem seus nutrientes, única e exclusivamente, de tecidos vivos. Exercem o parasitismo somente em plantas vivas e apresentam um alto grau de especificidade, sendo que a morte de tecidos do hospedeiro significa, portanto, o final do parasitismo desse grupo de patógenos, que não sobrevive em restos de cultura. Seu principal mecanismo de sobrevivência é o parasitismo de plantas voluntárias. Para seu controle, preconiza-se a eliminação das plantas voluntárias, principalmente, das espécies de inverno, como no caso, o trigo. Como exemplo de biotróficos pode-se mencionar os agentes causais da ferrugem da folha (Pucminia recondita f. sp. tritici), da ferrugem do colmo ( $P$. graminis f. $\mathrm{sp}$. tritici) e do oidio (Erysiphe graminis f.tritici), os quais, não são afetados pela prática da rotação de culturas. Os parasitas necrotróficos são aqueles que se utilizam de tecidos mortos como fontes de nutrientes. De uma maneira prática, poder-se-ia afirmar que vivem como saprófitas em plantas vivas. Isto significa que primeiro determinam a morte de pequenas áreas do limbo foliar, pela 
ação de toxinas ou de enzimas e, em seguida, a morte celular, passando a extrair seus nutrientes das áreas necrosadas. Desta feita, as manchas foliares constatadas são tecidos mortos, no hospedeiro vivo.

o agente causal do mal-do-pé do trigo (Gaeumannomyces graminis var. tritici) sobrevive no solo associado aos restos culturais, principalmente, em tecidos coromais das plantas. Se o trigo ou a cevada deixarem de ser cultivados na mesma área, tal patógeno é incapaz de parasitar a soja, a aveia, o tremoço ou a ervilhaca, ou qualquer outra cultura de inverno, sendo portanto, exclusivamente dependente, dos restos culturais do trigo ou da cevada. Ainda, o mencionado patógeno tem a habilidade de infectar as plantas quando estas estão vivas, podendo permanecer viável por, aproximadamente, um ano (REIS, 1986).

o agente causal da podridão comum do trigo (Bipolaris sorokiniana) sobrevive, principalmente, através de estruturas infectivas livres no solo, as quais permanecem dormentes sob micostase por até 37 meses (nIS, 1985b). Esse fungo se multiplica em órgãos aéreos de trigo, de centeio, de cevada, de triticale, menos na aveia. Depois da decomposição destes residuos o mesmo permanece na forma de espóro livre, no solo.

Ressalta-se que, as podridoes radiculares do trigo foram constatadas na quase totalidade das lavouras do Rio Grande do Sul e parte daquelas encontradas no do Paraná, 
ocasionando, severos danos à cultura (DIEHL et al., 1983 e $1984)$.

$$
\text { Os agentes causais da podridão da haste }
$$
(Sclerotinia sclerotiorum) e da podridão branca das raízes da soja (Sclerotium rolfsii) sobroivem através de estruturas infectivas lives no solo (esclerocios), os qua is permanecem viáveis por três a cinco anos (REIS, 1985a). Se estes esclerócios forem enterrados a mais de três centímetros de profundidade, não conseguirão lançar os espóros no ar. Portanto, uma lavra profunda ou preparo convencional, poderiam contribuir para a redução drástica desse patógeno. A permanência de esclerócios na superfície, em área manejada com programa contínuo de plantio direto irá beneficiar tais patógenos, provocando o aumento da intensidade dessas doenças.

O agente causal da rizoctoniose (Rhizoctonia solani) sobrevive no solo, saprofiticamente e ataca a soja ou outras plantas nativas de folhas largas ou cultivadas. Tal fungo é comumente encontrado no solo, apresentando portanto, dificil controle através da prática da rotação de culturas. Da mesma forma, a velocidade de decomposição dos restos culturais é um fator importante para a sobrevivência dos fungos que vivem a eles associados. As doenças da parte aérea do trigo e da soja, podem ser reduzidas pelo uso de sementes sadias, pela rotação de culturas, pela aplicação de fungicidas e pela resistência 
genética (MARCOS FILHO, 1986 e SANTOS et al., 1987a). No entanto, pela rotação de culturas do trigo ou da soja, com culturas não suscetíveis a essas doenças, consegue-se reduzir a drasticidade desses parasitas (SHANER, 1981; DIEHL, 1982; REIS et al., 1983; REIS, 1985a; SANTOS et al., 1990b). Neste caso, a referida prática agrícola leva os patógenos à i nanição.

A monocultura, por outro lado, realimenta os mesmos a cada 6-7 meses, tempo este requerido para que o trigo ou a soja voltem a ser cultivados na mesma área, que por sua vez, é o mesmo requerido para que ocorra a completa mineralização dos restos culturais, que é de aproximadamente 12 meses (REIS, 1985a; REIS et al., 1988 e SANTOS et al., $1987 d)$.

2.1.3. Efeitos de rotaço de culturas sobre o controle de plantas daninhas

Segundo LORENZI (1984b), a rotação de culturas permite controlar muitas espécies de plantas daninhas que vivem em sincronismo com determinada cultura. Cada cultura é, geralmente, infestada por plantas daninhas que possuem as mesmas exigências da espécie econômica e apresentam os mesmos hábitos de crescimento. Assim, o capim-arroz (Echinochloa crusgalli), em lavoura de arroz, o apaga-fogo (Alternanthera ficoidea), em lavoura de milho, o nabo 
(Raphanus raphanistrum), em lavoura de trigo e o carurúrasteiro (Amaranthus deflexu), em cana-de-açúcar, são alguns exemplos dessa associação. Quando são aplicados as mesmas práticas culturais, seguidamente, ano após ano, no mesmo solo, a associação plantas daninhas-cultura tende a ampliarse, refletindo, negativamente, na produção, na qualidade dos produtos e nos lucros (ANDERSON, 1983).

Consequentemente, a rotação de culturas deve ser programada de tal forma que, interrompa o ciclo biológico das plantas daninhas comuns e mais difundidas, utilizando-se espécies competitivas, cujo hábito de crescimento sejam bastante contrastantes; além do uso de técnicas culturais adequadas. A rotação de culturas quando é acompanhada do emprego de sementes isentas de propágulos de plantas daninhas, torna-se um método eficaz para manter o solo livre de espécies indesejáveis.

Nos conceitos mais modernos a prática da rotação envolve tanto culturas, como herbicidas. Desta maneira, combina-se as vantagens da rotação de culturas com a dos herbicidas, para utilizar-se os melhores produtos, com as melhores técnicas culturais requeridas pelas espécies econômicas. As plantas daninhas dificeis de serem controladas em uma cultura, podem ser facilmente controladas em outra; assim como as plantas daninhas perenes poderiam ser mais íceis de serem eliminadas se controladas nos estádios mais vulneráveis, durante a rotação. 
Trabalhos realizados por WALKER \& BUCHANAN (1982), mostram o valor da rotação de culturas e dos herbicidas para o aumento da produção das espécies econômicas e a influência no controle de plantas daninhas nas culturas do milho, da soja e do trigo. A aplicação de herbicidas no milho, em rotação, produziu $25 \%$ a mais do que esta gramínea em monocultura. Por outro lado, o milho em rotação, produziu 8\% a mais do que milho em monocultura. A soja em sistemas de rotação, produziu $14 \%$ a mais do que esta leguminosa semeada em monocultura. Ainda, ressaltam os autores que as espécies perenes de plantas daninhas infestaram os sistemas de monocultura mais intensamente do que os sistemas fundamentados na rotação de cultura.

Para DALE \& CHANDLER (1979), o controle do capim massambará (Sorghum halepense (L.) Pers., só foi efetivo na cultura do milho, quando esta graminea foi cultivada em rotação com algodoeiro. Além disso, a utilização de rotação de culturas impediu o aumento das populaçōes de outras espécies de plantas daninhas tanto anuais como perenes.

CHRISTOFFOLETI (1988), estudando o controle de Brachiaria decumbens Staf e de Cyperus rotundus L., em áreas de cana-de-açúcar, concluiu que a rotação com amendoim reduziu a infestação dessas espécies. Da mesma maneira, FERREIRA (1988), relata que, o uso mais frequente de cultura anual do tipo leguminosa (amendoim e soja) diminuiu o grau de 
infestação de plantas daninhas na cultura de cana-de-açúcar. Isto ocorreu, devido ao fato de que na cultura de cana-deaçúcar foram utilizados herbicidas seletivos para gramíneas, ou seja, efetivos para folhas largas. Quando uma leguminosa foi cultivada em intervalos menores, antes da cana-de-açúcar, a aplicacão de herbicidas seletivos em espécies de folha larga afetou as plantas daninhas de folhas estreitas, não permitindo a sua proliferaçã no amendoim ou na soja. Assim, houve menor infestação dè plantas daninhas na cana-de-açúcar, o que resultou em maior produtividade.

Pode-se deduzir que, a rotação de culturas deve ser relacionada com o controle de plantas daninhas em situaçðes particulares de sistemas de produção, bem como com o nível de infestação que cada produtor detectar em sua propriedade.

\subsubsection{Efeitos de rotação de culturas sobre o controle de pragas}

$$
\text { - surgimento de pragas está relacionado, }
$$

principalmente, à simplificação do agroecosistema, através do cultivo de extensas áreas com uma só espécie de plantas.

Nesta situação de monocultura, o uso de produtos fitossanitários é, praticamente, imprescindível. No entanto, pode-se reduzir o efeito negativo de inseticidas, através do manejo de pragas. Esta técnica preconiza a 
combinação de práticas agrícolas que objetivem reprimir as populaçơes de insetos-pragas e aumentar a ação de seus inimigos naturais, com o mínimo de efeito sobre o ambiente (GASSEN 1984 e 1986b).

A rotação de culturas apresenta-se como uma prática de controle, através da alternância de culturas não hospedeiras à praga. A eficiência desta prática está relacionada à duração do ciclo biológico, ao potencial de proliferação, ao grau de especificidade e ás características de dispersão dos insetos-pragas (GASSEN, 1986a).

$$
\text { Segundo SALVADORI (1991), a reduç } \widetilde{a ̆ o}^{\circ}
$$

populacional do tamanduá ou bicudo (Sternechus subsignatus), uma das pragas mais importante da soja, pode ser obtida através da rotação de culturas, principalmente, com o milho, uma vez que o inseto não ataca gramíneas.

A queima de restos culturais e a aração do solo, eliminam em parte alguns organismos vivos da lavoura, predispondo o surgimento de populaçðes de insetos que se alimẹtam da cultura subseqvente. A manutenção de restos culturais, na superfície do solo, beneficia o desenvolvimento de organismos vivos, especialmente, de inimigos naturais que controlam as pragas, GASSEN (1986a). 
2.1.5. Efeitos de rotação de culturas sobre algumas propriedades químicas do solo

A reciclagem de nutrientes é muito importante nos sistemas agrícolas, especialmente nos climas tropicais e sub-tropicais, onde é intensa a lixiviação de cátions básicos (cálcio, magnésio e potássio).

Para BALDOCK et al. (1981), a rotação de culturas, possui papel importante, na reciclagem de nutrientes, entre eles o nitrogênio.

Outros autores têm mostrado, a influência dos residuos culturais sobre as propriedades químicas do solo. Assim, BLACK (1973), demonstrou os efeitos da palha do trigo sobre os teores de matéria orgânica, nitrogênio, carbono e relação $\mathrm{C} / \mathrm{N}$, nas camadas de até $15 \mathrm{~cm}$ de profundidade, os quais aumentaram com as quantidades de palha adicionada ao solo. Em contrapartida, SANTOS \& REIS (1989) e SANTOS \& ROMAN (1989), conduzindo ensaios sob preparo convencional no inverno e sob plantio direto no verão, não verificaram efeitos relevantes nos níveis de nutrientes e de matéria orgânica do solo após os cultivos de inverno (aveia, cevada, colza, ervilhaca, linho, serradela, tremoço, trevo e trigo) e de verão (milho e soja). De uma maneira, depois de algumas sequências envolvendo leguminosas, houve aumento no $\mathrm{pH}, \mathrm{Ca}+$ Mg trocáveis e na matéria orgânica do solo. Para o pH e para os teores de $\mathrm{Ca}+\mathrm{Mg}$ do solo, este aumento se estendeu até o 
terceiro ano, diminuindo a seguir, em função da perda do efeito residual do calcário.

Por outro lado, estudos feitos por DERPSCH et al. (1985), com algumas espécies de plantas para adubação verde, revelaram que a aveia preta e o nabo forrageiro, deixaram nos seus residuos, quantidades de nitrogênio superiores às leguminosas. Desta maneira, a adubação verde com aveia preta ou nabo forrageiro, em valores absolutos, pode determinar, também, rendimentos mais elevados para a cultura da soja e do feijoeiro, em relação as espécies leguminosas. Além disso, as gramíneas possuem relação $\mathrm{C} / \mathrm{N}$ superiores às leguminosas, nas quais a sua decomposição é mais lenta, o que pode facilitar o seu aproveitamento pelas espécies subseqüentes. No caso do milho, os mesmos autores, obtiveram os maiores rendimentos, em valores absolutos, após leguminosas de inverno (tremoço e ervilhaca). *

2.1.6. Efeitos de rotação de culturas sobre as plantas

A cobertura vegetal do solo pode proporcionar, tanto efeitos positivos como negativos, sobre os sistemas de produção. Os efeitos positivos são observados no controle de plantas daninhas, da erosão e da oportunidade de semeadura das culturas em sua melhor época. os negativos estão relacionados aos efeitos alelopáticos sobre o desenvolvimento e sobre a diminuição do rendimento de grãos das culturas em 
sucessão (PATRICK et al., 1964; KRONSTAD et al., 1978; ALMEIDA, 1988; SANTOS \& REIS, 1991). Para ALMEIDA (1988) esse efeito está relacionado diretamente, com a quantidade de palha da cultura anterior.

Desta maneira, entende-se por alelopatia qualquer efeito causado, direto ou indiretamente, por uma planta sobre outra, através da elaboração de produtos químicos liberados no ambiente (RICE, 1984).

Nos trabalhos realizados por SANTOS \& REIS (1990 E 1991), SANTOS (1991) e SANTOS et al. (1991b e 1991c) foram observados que os restos culturais da cevada, do trigo e da aveia, facilitaram a semeadura e o desenvolvimento da soja. Por outro lado, os restos culturais da aveia (branca e preta) para produção de grãos, originaram uma grande quantidade de palha, enquanto que, o linho proporcionou menor quantidade; todavia, dificultando o estabelecimento e o desenvolvimento da soja. Desta maneira, a semeadora de plantio direto não conseguiu cortar a palha da aveia deixada na superficie e nem distribuir a semente da soja, dentro do solo a uma profundidade desejada. Estes problemas são agravados, principalmente, em período de escassez de chuvas, logo após a colheita, devido a menor taxa de decomposição dos resíduos de aveia, nessas condições. Além Gsos, verificou-se que a soja após tal gramínea, apresentou ao longo do ciclo, menor altura de plantas e folhas com coloração verde menos 
intenso, em relação aos demais tratamentos com essa leguminosa, recuperando-se, em parte, no final do seu ciclo.

ALMEIDA (1985), observou que, a cobertura morta do nabo forrageiro reduziu o crescimento inicial do milho, atribuindo isto a um efeito alelopático, sem contudo identificar a substância responsável. Ainda, ALMEIDA et al. (1984), verificaram a existência de efeitos alelopáticos (estimulo, retardamento, ou inibição da germinação de sementes) de diversas coberturas mortas sobre diferentes plantas daninhas, em experimentos conduzidos em vaso. Em condiçðes de campo, contudo, estes efeitos são dificeis de serem comprovados, devido a grande diluição das substâncias alelopáticas no solo e por sua rápida decomposição pelos microorganismos.

Contudo, trabalhos mais antigos revelaram que, quando a monocultura foi praticada durante anos seguidos, evidenciava-se a liberação de alguns compostos, durante a decomposição dos restos vegetais, que se acumulavam no solo até atingirem concentraçðes inibidoras do crescimento da própria planta (ALMEIDA, 1988). Para que isto fosse evitado, recomendava-se a prática da rotação de culturas. Entretanto, como pode ser observado, a inibição alelopática não é somente sobre plantas de diferentes espécies. Segundo KATZNELSON (1972), o exemplo mais expressivo de autoinibição é do trevo vermelho, conhecido na Europa desde o século XVII. 
No Brasil, em trabalhos desenvolvidos pelo Centro Nacional de Pesquisa de Trigo, Passo Fundo, RS, observou-se que a soja em monocultura ou após a colza, produziu menos e apresentou menor altura de plantas, quando camparada com esta leguminosa em rotacão com o milho (SANTOS \& REIS, 1991 ).

ALMEIDA \& RODRIGUES (1985), observaram que a resíduos de aveia, de centeio, de azevém, de azevém + ervilhaca e de nabo forrageiro, colhidos no mesmo dia, deixaram o terreno mais limpo de plantas daninhas do que em relação ao trigo, ao triticale e ao tremoço.

SANTOS \& REIS (1991), verificaram o efeito negativo dos restos culturais da colza sobre a soja em plantio direto, diminuindo a altura das plantas e sua produtividade. Isto tem sido verificado, em períodos secos, com má distribuição de chuvas, durante o estabelecimento e o desenvolvimento da soja após a colza.

TRINANES SCHAFFNER \& URIARTE BREGANTE (1984), avaliaram o efeito alelopático do residuo vegetal de algumas culturas de verão (girassol, milho, soja e sorgo) sobre o crescimento e produção do trigo. Concluiram os autores que o colmo do sorgo foi a parte da planta que mais efeito depressivo causou ao trigo, enquanto que, o girassol e o milho, como um todo, situaram-se em posição intermediária. As raízes da soja, constituiram na parte da planta que mais efeito danoso causou ao trigo. 
Na escolha das culturas de inverno ou de verão que irão preceder a seqüência, deve-se considerar, não só a ação alelopática sobre as espécies cultivadas, mas, também, sobre as plantas daninhas.

2.1.7. Efeitos de rotação de culturas sobre conservação do solo

Um dos maiores problemas da agricultura intensiva no Brasil é a erosão. A textura troor de matéria orgânica do solo, a declividade do terreno, o sistema de preparo de solo, as práticas culturais empregadas, a rugosidade superfícial do solo, a quantidade e a qualidade de cobertura vegetal e a própria cultura são fatores que influenciam a intensidade de erosão (ALMEIDA \& RODRIGUES, 1985). O revolvimento do solo, destrói a estrutura, o qual, quanto mais intensivo mais suscetivel à erosão.

A principal causa da erosão é o impacto direto da gota da chuva no solo descoberto. A maneira mais racional de, controlar a erosão consiste em evitar-se o impacto da gota no solo pela interposição de camadas de resíduos vegetais (WUNSCHE \& DENARDIN, 1978). No plantio direto, os residuos das diversas espécies integrantes do sistema de rotação ou sucessão de culturas (após a colheita), mais os das plantas siłvestres, permanecem na superfície (ALMEIDA, 1985). Esta proteção do solo é fundamental para o controle da erosão. 
Deste modo os resíduos culturais permanecem na superfície, o que reduz o contato destes com os microorganismos, propiciando menor taxa de decomposição, favorecendo a proteção e o enriquecimento do solo.

Trabalhos desenvolvidos por CASSOL et al. (1987), com manejo de solo e de culturas, sob chuva natural, na região de Ijuí, RS, no inverno e no verão, comprovaram que o plantio direto, constituiu-se numa das mais eficientes práticas de controle da erosão.

A influência da cultura na proteção do solo depende da densidade da cobertura que lhe é proporcionada, uma vez que as perdas de solo se verificam, essencialmente, no período inicial de crescimento. VIEIRA (1977) demostrou que $90 \%$ da erosão, ocorrida durante o ciclo da soja, se observa nos primeiros 30 dias, período em que se verifica alta pluviosidade e o solo se encontra mais desprotegido. Por outro lado, quanto maior for a quantidade de resíduos produzidos e menor for a taxa de decomposição, maior será a proteção oferecida.

Os cereais, tais como aveia, cevada, milho, trigo e triticale, satisfazem essas condições, pois apresentam alta densidade populacional, desenvolvimento relativamente rápido e, depois de destruídos ou colhidos, deixam no terreno, residuos abundante, densa e de decomposição lenta (SANTOS et al., 1990c). Além disso, as gramineas possuem sistema radicular abundante, que funcionam 
como uma rede mantendo os agregados de solo, tornando-os mais resistentes a ação do impacto da gota de chuva e ao transporte pela enxurrada (DECHEN et al., 1981). Já, o residuo de soja, de feijoeiro, de colza e de girassol, produzem pequenas quantidades de residuos e com alta percentagem de folhagem, que por sua vez, se decompõem rapidamente, resultando em cobertura desuniforme e pouco densa. Por outro lado, as restevas de ervilhaca e de serradela, comparativamente às espécies mencionadas, ocupam posição intermediária quanto à persistência no solo (SANTOS et al., 1990c).

A quantidade e a qualidade da cobertura vegetal vai depender da adequação do sistema de rotação ou sucessão de culturas, objetivando a estabilidade produtiva e a redução das perdas do solo pelo controle de erosão.

2.1.8. Interação entre manejo de solo e rotação de culturas

Tem sido observado, à nível experimental que, quando se inicia a monocultura de trigo em áreas livres de doenças radiculares, os rendimentos somente começam a declinar com maior intensidade, após o terceiro ou quarto ano de cultivo. Nota-se ainda, que a maior ou menor incidência desses potógenos estaria ligado não só ao monocultivo de trigo, mas, também seria dependente das culturas anteriores 
e do sistema de preparo de solo da área onde seria implantado este cereal (PEREIRA, et al., 1985 e REIS \& AMBROSI, 1987). Trabalhos conduzidos no Centro Nacional de Pesquisa de Trigo (CNPT), a partir de 1980 (SANTOS et al., $1987 \mathrm{a}, 1988$ e 1990a), visando estudar alguns sistemas de rotação para trigo, revelaram que o rendimento de grãos de trigo após alguns anos, em monocultura, tornaram-se, praticamente nulos e melhoraram consideravelmente, nos últimos anos (1984 a 1987), pelo preparo do solo com arado de aiveca, associado às boas condiçđ̃es climáticas. Em 1988, o rendimento de grãos de trigo, continuou, relativamente elevado, mas com o solo preparado com arado de disco e clima semelhante ao dos anos anteriores (SANTOS et al., 1989a). Notou-se, também, que as doenças do sistema radicular estavam se manifestando em menor intensidade e nas fases menos criticas da cultura. Mesmo nestas condiçðes, as doenças de sistema radicular, ocorreram com maior intensidade na monocultura de trigo, em comparação aos demais sistemas que envolvem rotação de culturas. WIETHULTER (1978), observou uma redução de incidência de mal-do-pé e um incremento no rendimento devido à lavra a uma profundidade maior, pelo efeito de diluição do inóculo, provocado pela inversão e pelo revolvimento das camadas superiores do solo.

O inóculo de alguns fungos, que causam doenças radiculares é consequência da multiplicação em tecidos mortos deixados na superficie do solo. REIS \& ABRÃO (1983), 
verificaram que $67 \%$ dọs propágulos do agente causal da podridão comum concentram-se na camada superficial de $0-5 \mathrm{~cm}$, $23 \%$ na de $5-10 \mathrm{~cm}, 8 \%$ na de $10-15 \mathrm{~cm}$ e apenas $2 \%$ na camada de 15-20 cm. Da mesma forma que o inóculo do agente causal do mal-do-pé, aquele relacionado à podridão comum pode ser diluido pela ação dos implementos de preparo de solo que revolvem as camadas mais profundas. E, ainda, como são dependentes de fatores como temperatura e umidade de solo, as moléstias poderão ocorrer em menor ou maior intensidade até ao final do ciclo da cultura do trigo, conforme a variação destes fatores. Naturalmente que, sob plantio direto, sem preparo de solo, a concentração é ainda mais acentuada nas camadas mais superficiais (REIS \& ABR ÃO, 1983; REIS\& BAIER, 1983; REIS, 1984).

Nos estudos com sistemas de rotacão para trigo e para cevada, em plantio direto, no estado do F'araná, não tem sido observado diferença entre as médias para rendimento de grãos, provavelmente, devido às boas condiçơes climáticas (SANTOS et al., 1989b e 1991a). Da mesma forma que, no estado do Rio Grande do Sul, a intensidade de doenças do sistema radicular, manifestam-se com menor intensidade, é todavia, mais elevada na monocultura deste cereal do que, em comparação aos demais sistemas que usam rotação de culturas. Trabalhos realizados no CNPT, com diferentes tipos de manejo de soro e de sistemas de fondução, mostraram diferenças entre as médias para rendimento de grãos e para 
intensidade de mancha amarela da folha (Dreschlera triticisrepentis) do trigo (SANTOS et al., 1990d). O rendimento de grãos foi mais elevado sob plantio direto e sob cultivo mínimo, em relação ao sistema convencional de preparo, caracterizado pelo uso de arado de aiveca e de disco, em ano relativamente seco. O oposto foi constatado para a intensidade de mancha amarela da folha, ou seja, houve maior intensidade na monocultura, em comparação aos demais sistemas de cultivo para trigo em rotação. Isto vem demonstrar, também, o efeito benéfico da rotação, sobre as doenças da parte aérea do trigo.

Pelo exposto pode visualizar-se que, a rotação de culturas torna viável o sistema plantio direto, além de permitir o biocontrole das plantas daninhas e das doenças de trigo, sem a utilização de produtos especificos.

\subsubsection{Interação entre clima e rotação de culturas}

A possibilidade e a distribuição das culturas bem como os rendimentos anuais, dependem, em grande parte, do clima (MOTA, 1982). Esta afirmação tem sido especialmente válida no Brasil, no que se refere a cultura de trigo. No caso de monocultura desse cereal, quando houve condiçסes desfavoráveis, isto é, chuvas frequentes e temperaturas ideais para as doençâs do sistema radicular, durante as fases 
criticas da cultura, o rendimento de grãos apresentou tendência de diminuição (SANTOS et al., 1990a).

Os efeitos da rotaçãolicam melhor demonstrados, principalmente, em anos com excesso de precipitaçðes pluviais. REIS et al. (1983) e SANTOS et al. (1988 e 1987a) comparando a monocultura do trigo, com um ou dois invernos de intervalo, em ano considerado satisfatório e anormal para a cultura, verificaram que as doenças do sistema radicular foram controlados pela uso de dois invernos de rotação de culturas. A eficiência da rotação de culturas, com espécies não suscetiveis, em reduzir a inlensidade das podridðes em trigo, foi notadamente marcante em 1982, ano mais úmido e, portanto, mais adverso à cultura do que o de 1981, ano considerado propício ao desenvolvimento deste cereal. Em 1981, no período de junho a novembro, houve uma precipitação total de $665 \mathrm{~mm}$, ao passo que no mesmo período de 1982 foi constatado $1.331 \mathrm{~mm}$, sendo que a normal para a região corresponde a $994 \mathrm{~mm}$.

Portanto, a rotação de culturas, visa acima de tudo propiciar, mesmo em anos climaticamente adversos ao trigo, estabilidade de rendimento e segurança ao produtor na obtenção da renda agrícola. 
2.1.10. Efeitos da rotação de culturas no rendimento de algumas plantas cultivadas

Há mais de vinte anos, no Rio Grande do Sul, baseados em observações de lavouras e de alguns experimentos realizados, alguns técnicos definiram ser a sucessão de culturas o principal meio para obter-se uma maior estabilidade de rendimentos de grãos na cultura de trigo. Para KALCKMANN \& OLIVEIRA (1962), PATELLA \& KALCKMANN (1963) e KALCKMANN (1970), a prática da rotação de culturas, seria a única medida fitossanitária de que se disporia para evitar a forte pressão de inóculo de determinados parasitos. Ainda, se constituiria em uma maneira de reduzir os custos de produção das lavouras, além de promover a diversificação de culturas e a consequente diminuição de risco. E, seria, também, um fator de manutenção ou mesmo de melhoria da fertilidade e conservação do solo.

Durante algum tempo, houve uma falta de continuidade de trabalhos de pesquisa nessa área, pois a atenção estava voltada para o cultivo de soja, cujo grăo alcançava altos preços no mercado, bem como para a moderna tecnologia recomendada nessa época para o cultivo de trigo (utilização de fungicidas no controle de doenças).

A partir de 1975, o Centro Nacional de Pesquisa de trigo iniciou trăbalhos com espécies alternativas, visando estudar os efeitos da prática de rotação de culturas no 
comportamento de cinco espécies alternadas: trigo, cevada (no inverno), soja, milho e sorgo (no verão) (PEREIRA \& BOUGLE, $1976 \mathrm{a}$ e 1976b).

PEREIRA et al. (1984), mostraram que, a simples alternância de trigo com cevada, durante cinco anos, propiciou melhores rendimentos de grãos, do que quando se cultivou trigo em monocultura. PATELLA (1978), em experimento conduzido durante 15 anos, obteve o melhor resultado com o binômio trigo e soja, em anos alternados, do que em relação ao trigo em monocultura. REIS et al. (1983) observaram que os rendimentos de grãos obtidos na monocultura de trigo foi o mais baixo $(377 \mathrm{~kg} / \mathrm{ha})$, com um ano de rotação foi intermediário $(1.045 \mathrm{~kg} / \mathrm{ha})$ e, com dois anos, o mais elevado $(2.320 \mathrm{~kg} / \mathrm{ha})$.

SANTOS et al. (1990b), avaliando sistemas de rotação para trigo, verificaram que este apresentou maiores rendimentos de grãos quando alternado por tremoço e colza, em comparação com aveia e linho. Em contrapartida, SELMAN (1975), obteve melhores rendimentos de grãos de trigo quando este foi intercalado por um ano com feijoeiro, ou por dois anos com aveia e com feijoeiro, quando comparado à monocultura desse cereal.

Desta maneira, a monocultura de trigo pode afetar negativamente o rendimento de grãos e os componentes de rendimento dessargramínea. Pesquisa com trigo de inverno mostrou que intercalando-se aveia ou feijoeiro a esta 
cultura, evidencia-se maior produção que a monocultura dessa gramínea (SLOPE \& ETHERIDGE, 1971). SANTOS et al. (1988), observaram que nos sistemas de rotação com trigo após colza, linho e tremoço ou serradela, trigo após aveia e trigo após colza, cevada e tremoço ou serradela, o rendimento de grãos; o peso de 1.000 sementes e o peso do hectolitro foram superiores à monocultura de trigo. Da mesma forma, a intensidade das doenças do sistema radicular diminuiu à medida que aumentou-se o período de rotação. No caso de soja, quando esta leguminosa foi cultivada após a colza ou em monocultura sucedendo o trigo, manifestou efeito negativo, quanto ao rendimento de grãos (SANTOS \& REIS, 1991).

2.1.11. Efeitos da rotaça de culturas na eficiência energética de sistemas de produção

Sob o ponto de vista energético, vários trabalhos são listados na literatura, sendo alguns deles coordenados, principalmente, por PIMENTEL (1980b). Nestes trabalhos foram contabilizadas, detalhadamente, a energia gasta para obtenção dos principais insumos e transporte da fábrica até a propriedade, bem como a energia gasta nas operações de campo (semeadura, tratos culturais e colheita). Também foram avaliados diversos sistemas de produção agrícola, em diferentes locais dos Estados Unidos da América. Dentre esses estudos, destacaram-se as estimativas do balanço 
energético para as culturas de aveia (WEAVER, 1980), de cevada (BUKANTIS \& GOODMAN, 1980), de milho (PIMENTEL \& BURGESS, 1980), de soja (SCOTT \& KRUMMEL, 1980) e de trigo (BRIGGLE, 1980).

Por sua vez, BERARDI (1978) comparou a energia gasta para a produção de trigo com diferentes tecnologias, ou seja, com a utilização de insumos que demandaram altas e baixas quantidades de calorias. O autor concluiu que o sistema que dispendeu mais energia ( $48 \%$ ), produziu $29 \%$ mais do que o segundo que, usou menos energia.

No Brasil, destaca-se o trabalho desenvolvido por MELLO (1986) estimando diversos sistemas de produção, envolvendo as culturas de feijoeiro, milho e soja, para o estado de Santa Catarina, sob preparo convencional. Desta forma, o cultivo de milho, que utilizou tração animal, trabalho humano e fertilização orgânica, gastou menos energia para obter uma unidade de produto para cada Mcal (Kcal $\mathbf{x}$ 1.000) investida na cultura, do que o sistema mecanizado e com insumos químicos. Neste caso, as variaçós nos produtos obtidos por Mcal investida na cultura, foram proporcionais aos níveis de utilização da mecanização e insumos químicos. Deve ser levado em consideraçăo que o autor preconizou para o milho um sistema com produtividade em torno de 5.000 e $6.000 \mathrm{~kg} / \mathrm{ha}$. 
2.1.12. Efeitos da rotação de culturas na eficiência econômica de sistemas de produção

MARTIN et al. (1984), considerando a rotação de culturas sob o ponto de vista econômico, à nivel de lavoura, obtiveram aumentos na produtividade quando utilizaram esta prática agrícola. A soja quando semeada após milho + mucuna, apresentou $16 \%$ de rendimento superior a monocultura. Neste caso foi usado, somente $20 \%$ do herbicida, além de menores quantidades de nutrientes e de inseticidas. Neste mesmo ensaio, o algodoeiro em rotação, rendeu 5\% a mais do que em monocultura.

No estudo de várias combinaçôes de rotação ou de sucessão de culturas para soja, no estado do Paraná, desenvolvido no Centro Nacional de Pesquisa de Soja, revelaram que, com milho em rotação com a soja, aumentou o rendimento dessa leguminosa nas duas safras seguintes, na quase totalidade dos arranjos, em relação a monocultura (GAUDENCIO et al., 1986). Isto mostra que, o cultivo de milho em um ou dois verós seguidos, antes da soja, pode melhorar o rendimento da mesma, independentemente, das culturas de inverno envolvidas no programa.

ZENTNER et al. (1990), avaliando os aspectos econômicos dos sistemas de rotação para cevada ou trigo, no Sul do Brasil, no período de 1984 a 1988, revelaram que a maior receita liquida foi obtida com apenas um ano de rotação 
de culturas para ambas as espécies. A performance econômica de dois ou três anos de rotação de culturas foi intermediária, enquanto que, sob monocultura a receita líquida foi menor. Deve ser levado em consideração que, as culturas de verão foram as espécies que apresentaram maior receita liquida, dentre as quais destaca-se o milho. Isto, por sua vez foi relacionado diretamente com o desempenho agronômico, cujos rendimentos estiveram em torno de 7.211 $\mathrm{kg} / \mathrm{ha}$, nesse período.

Estudos econômicos de sistemas de manejo de solo, com enfoque de análise de decisão, desenvolvidos por SALOMÃO (1990), revelaram que as maiores produtividades de milho, soja e trigo foram obtidas com o sistema plantio direto, em níveis que variaram conforme o programa de rotação de culturas adotado. O mesmo autor concluiu ainda que, o plantio direto mostrou desempenho superior em anos climaticamente desfavorável para as três espécies, sob qualquer rotação.

2.2. Espécies vegetais de inverno para rotaçăo no sul do Brasil

A escolha das culturas que poderão integrar um sistema de rotação depende de fatores técnicos e econômicos. Dentre os fatores técnicos podem ser citados: a adaptação das culturas à região, influindo no risco de 
investimento; o aspecto fitossanitário em relação ao controle de doenças e de pragas; a possibilidade de uma cultura atuar como planta daninha nos cultivos subsequentes ou, de forma inversa, permitir o seu controle; o valor da tecnologia disponível para a cultura; a disponibilidade de equipamento e de mão-de-obra necessária para a sua exploração (SANTOS et al., 1987d). Além disso, as culturas alternativas de inverno têm apresentado problemas le produção de sementes.

Entre os fatores econômicos básicos estariam aqueles relativos ao custo de produção; à segurança de mercado e à disponibilidade de crédito para exploração.

Além dos fatores técnicos e econômicos, o agricultor exercerá a sua escolha pessoal decidindo de forma preferencial entre culturas, tipos de exploração ou combinação de culturas.

No Centro Nacional de Pesquisa de Trigo (CNPT), estão sendo estudadas, desde 1979, algumas culturas alternativas de inverno, destacando-se no controle das doenças do sistema radicular de trigo e na proteção superficial do solo, sem considerar o valor econômico, a aveia, a colza, o linho, a ervilhaca e a serradela.

De acordo com SLOPE \& ETHERIDGE (1971), a aveia pode ser utilizada em rotação com o trigo, pois é praticamente, imune ao mal-do-pé. Nos ensaios de sistemas de rotação para trigo, desenvolvidos no CNPT, esta gramínea tem apresentado rafizes mais sadias e produzido mais quando 
antecedida por aveia branca (para cobertura do solo ou para produção de grãos), linho e leguminosas, em comparação com a monocultura desse cereal (SANTOS et al., 1986, 1987a, 1987b e $1987 \mathrm{c}, 1988,1990 \mathrm{~b}$ e $1990 \mathrm{c}$ ). A aveia branca para cobertura de solo no inverno e para produção de grãos, o linho e as leguminosas constituem-se, no momento, as melhores opç̃es de rotação para controlar as doenças do sistema radicular de trigo.

A escolha de espécies que poderão constituir um sistema de rotação de culturas depende de vários fatores, entre os quais incluem-se a habilidade para solucionar problemas específicos (por exemplo, controle de doenças radiculares), a finalidade de uso (para grãos, forragem ou cobertura de solo), e principalmente, os aspectos econômicos. As leguminosas tem sido utilizadas desde a antiguidade, para diversas finalidades. Assim, elas tem sido úteis para controlar doenças, plantas daninhas e insetos (SHRADER et al., 1962 e LORENZI, 1984a), para diminuir a erosão de solo (WISCHMEIER, 1960) ou a inda, com a finalidade de fornecer nitrogênio à cultura seguinte (SUTHERLAND et al., 1961; GALLO et al., 1981; HESTERMAN et a l., 1986; BRUULSEMA \& CHRISTIE, 1987). Algumas leguminosas são de importância econômica, como soja (Glycine max L.), enquanto outras espécies de inverno tem sido usadas, principalmente, para cobertura e adubação verde, como ervilhaca (Vicia sativa L.), serradela (Ornithopus sativus brot), tremoço (Lupinus sp.) e outras. 
No Sul do Brasil, as leguminosas, como chicharo (Lath.rus sativus L.), ervilhaca, serradela, tremoço e trevo ( Trifolium spp) tem sido recomendadas para cobertura de solo e para adubação verde (DERPSCH et al., 1980; SCHERER, 1982; DERPSCH \& CALEGARI, 1985; SANTOS et al., 1987d; SANTOS \& P(iTTKER, 1990). O valor das leguminosas como adubo verde, pode ser melhor avaliado quando considerada sua contribuição como fonte de nitrogênio, pois o seu uso foi mais eficiente do que a utilização de $80 \mathrm{~kg} / \mathrm{ha}$ de nitrogênio na produção de milho (MUZILLI, 1978). Nas comparaçðes entre espécies de leguminosas de inverno, não foram observadas variaçðes entre as médias de rendimento de grãos de milho, quando este foi antecedido por trevo e tremoço (SANTOS et al., 1987c), por ervilhaca, serradela e tremoço (MUZILLI, 1978), por ervilhaca e serradela (SANTOS et al., 1987c e SANTOS \& PUTTKER, 1990) ou por ervilhaca e tremoço (SANTOS et al., 1987e). Resultados mais recentes, considerando-se dados de cinco anos, comparando-se o rendimento de grãos de milho após ervilhaca ou após tremoço, mostraram diferença entre a média dessa gramínea após a primeira leguminosa, em relação a segunda, respectivamente (SANTOS et al., 1989b).

A ervilhaca tem apresentado ótimo desempenho no Sul do Brasil, quando semeada precedendo ao milho e a outras culturas não leguminosas. Esta espécie tem apresentado melhor desevolvimento inicial, cobertura eficiente do solo e controle de plantas daninhas quando comparada ás culturas de 
tremoço e de serradela (SANTOS \& PUTTKER, 1990). Assim sendo, no momento, a leguminosa de inverno de maior potencial para uso em rotações de cultura com o trigo tem sido a ervilhaca.

\subsection{Sistema Plantio direto}

Sob o ponto de vista conservacionista, o sistema plantio direto constitui-se numa das mais eficientes práticas de controle da erosão, o que seria suficiente para justificar a sua aplicação (FANCELLI \& FAVARIN, 1987). Contudo, são apontados, por pesquisadores e agricultores, outros beneficios de natureza diversa em decorrência da adoção desse sistema de produção.

No Brasil, os estudos sobre plantio direto tiveram inicio em lavouras de trigo e de soja, em Londrina, Paraná, no ano de 1971 , por iniciativa empreendida pelo Instituto de Pesquisa e Experimentação Agropecuária Meridional (IPEAME), sendo aceito posteriormente, pelos agricultores dessa região e da região dos Campos Gerais do Paraná (MUZILLI, 1981). Somente algun tempo depois, o plantio direto chegou aos estados do Rio Grande do Sul, São Paulo e Mato Grosso (ALMEIDA \& RODRIGUES, 1985).

Em 1973, a Companhia de Indústrias Químicas do Brasil (ICI), iniciou uma série de experimentos, no Rio Grande do Sul, sobre herbicidas visando o desenvolvimento do sistema plantio direto (BARKER \& WUNSCHE, 1977). Juntamente 
com esse trabalho, outras Instituições de pesquisa, tais como o Centro Nacional de Pesquisa de Trigo - EMBRAPA, Centro de Experimentação e Pesquisa - FECOTRIGO, Instituto de Pesquisas Agronômicas - Secretaria da Agricultura, RS, Departamento de Fitotecnia - Universidade Federal do Rio Grande do Sul e Universidade lederal de Santa Maria, também iniciaram estudos básicos do manejo e conservacăo de solo, em relacáo ao plantio diroto.

Dentre esses benefícios, tem-se observado, à nivel experimental e de lavoura, que com o plantio direto é possivel estabelecer-se as culturas de inverno e de verão, dependendo da região, na época de plantio mais adequada (SANTOS et al., 1987e, $1987 \mathrm{f}$ e 1991b), pois pela redução do número de operações de preparo de solo, economiza-se tempo. Esta redução é de fundamental importância no sentido de assegurar a possiblidade do uso de sistemas de rotação de culturas.

No decorrer da condução do sistema plantio direto, tem-se observado uma diminuição na incidência de algumas plantas daninhas, pelo fato de não revolver-se grandes quantidades de solo, o que contribui, também, para reduzir os custos de produção. LORENZI (1984b), relata a tendência de ocorrência de plantas daninhas anuais em menor escala no plantio direto, em comparação com o preparo convencional.

Esta prática proporciona maior conservação de 
umidade no solo e melhor aproveitamento de água disponível pelas plantas (SIDIRAS et al., 1984), principalmente, por parte de espécies que permitem cobertura vegetal adequada, em anos com periodos de estiagem relativamente prolongados (SANTOS et al., 1987f). Em ano relativamente seco, o trigo em plantio direto e cultivo mínimo, produziu mais do que sob o sistema de preparo convencional (preparo do solo com arado de aiveca e com arado de disco) (SANTOS et al., 1990d).

Assim, em solos sob plantio direto ocorre menor evaporação e, conseqüentemente, há uma maior conservação de umidade (VIEIRA, 1981).

Por outro lado, a manutenção de umidade no solo sob sistema plantio direto, por mais tempo, pode favorecer a compactação do solo, devido ao tráfego de máquinas (facilitado mesmo em condiçơes de umidade) como decorrência de sua plasticidade e pegajosidade (VIEIRA, 1985).

De acordo com MUZILLI (1985), o sistema plantio direto pode produzir mudanças nas propriedades químicas do solo, cujos efeitos se refletem diretamente, na fertilidade e eficiência de aproveitamento de nutrientes pelas plantas. A localização dos corretivos e adubos aplicados na superfície do terreno, sem a sua incorporação física, também altera a distribuição e acumulação de nutrientes, influenciando a sua disponibilidade e aproveitamento pelas plantas.

Nos trabalhos conduzidos no Instituto Agronômico do Paraná, não se constatou a ocorrência de 
acidificação de solo na camada arável sob plantio direto (MUZILli, 1983). Após vários anos de cultivo, os valores de $\mathrm{pH}$ do solo encontrados em plantio direto ainda se mostravam semelhantes, ou superiores, aos verificados sob preparo convencional. Ao contrário do esperado, a acidificação foi mais acentuada no sistema convencional de preparo. O cálcio e o magnésio tenderam a se acumular na camada superficial com a diminuição gradativa da disponibilidade nas camadas mais profundas do solo, sob plantio direto. Nos estudos efetuados por BOUGLE \& PEREIRA (1978) e SIDIRAS \& PAVAN (1985), verificou-se que sob plantio direto, em relação ao preparo convencional, houve aumento de $\mathrm{pH}$, de teores de $\mathrm{Ca}+\mathrm{Mg}$, de $P$ e de $K$ no solo e, como consequência, verificou-se diminuição no Al, principalmente nos horizontes próximos ả superficie. Ainda, de acordo com PAVAN (1985), em plantio direto, a tendência de acidificação do solo é menor em virtude da mineralização mais lenta e gradativa da matéria orgânica acumulada na superfície, não proporcionando a acumulação intensiva de ácidos orgânicos na camada arável, além do maior teor de umidade provocar a diluição da concentração de ácidos liberacios.

Por outro lado, SANTOS \& LHAMBY (1992) e SANTOS \& SIQUEIRA ( 1992 ), estudando sistemas de rotação de culturas em plantio direto, observaram que, os valores de $\mathrm{pH}$ e $\mathrm{Ca}+\mathrm{Mg}$ aumentaram, enquanto que, os teores de Al, de matéria orgânica, de $\mathrm{P}$ e de $\mathrm{K}$ diminuiram, da superficie $(0-5 \mathrm{~cm})$ até 
as camadas mais profundas de solo $(10-15 \mathrm{~cm})$, verificando, também, um processo de acidificação do solo a partir da superficie. Ainda, os mesmos autores, fizeram o balanço nutricional em relação ao cultivo de diferentes espécies e não observaram efeitos relevantes dos diversos sistemas de cultivos sobre os níveis de nutrientes e os teores de matéria orgânica, na camada arável de solo.

Estudos feitos por MUZILLI (1983), revelaram que, tanto em plantio direto como em preparo convencional, a camada arável do solo tem seu teor de matéria orgânica aumentado com o tempo de cultivo, sendo similares os efeitos proporcionados pelos dois sistemas. As deficiências de nitrogênio foram mais acentuadas nas culturas de milho e de trigo em plantio direto do que em preparo convencional, evidenciando maior necessidade de adubação nitrogenada pelas culturas no primeiro sistema, com o decorrer do tempo. As gramineas cultivadas, em geral, muito exigentes em nitrogênio, beneficiam-se diretamente do resíduo da adubação nitrogenada e da flora microbiana que permanece no solo após a retirada de leguminosas. A inclusão de soja nos esquemas de rotação possibilitou reduzir a deficiência de nitroĝênio nessas culturas. MASCARENHAS et al. (1986) constataram, no estado de São Paulo, que a quantidade de nitrogênio remanescente no solo após vários cultivos de soja, era suficiente para atender a demanda da cultura de milho. Assim, uma alternativa para se reduzir a necessidade de nitrogênio 
em plantio direto é a inclusão de espécies leguminosas nos esquemas de rotação.

De acordo com MUZILLI (1983), no plantio direto houva maior acúmulo de fósforo e melhor aproveitamento deste pelo milho, evidenciando a possibilidade de redução da adubação fosfatada. A distribuição de potássio foi similar entre os sistemas de cultivo, indicando que, para o plantio direto, devem prevalecer os mesmos critérios de orientação para adubação potásica preconizada para o preparo convencional, ao se tomar a análise de solo, como base. 
3. MATERIAL E MÉTODOS

o presente estudo foi desenvolvido no periodo compreendido entre 1990 e 1991, como parte de um experimento instalado desde 1984, em área dà Cooperativa Agrária Mista Entre Rios Ltda., em Guarapuava, PR, sob coordenação da área dè Manejo e de Tratos Culturais do Centro Nacional de Pesquisa de Trigo (CNPT), Passo Fundo, RS. Ressalta-se que neste mesmo local, vinha sendo cultivado cevada e trigo, anteriormente.

\subsection{Clima}

A área experimental de Guarapuava está situáda a $25^{\circ} 23^{\circ}$ de latitude sul, $51^{\circ} 29^{\circ}$ de longitude oeste e a $1095 \mathrm{~m}$ de altitude (INSTITUTO BRASILEIRO DE GEOGRAFIA E ESTATISTICA, 1959). O clima da região é considerado temperado ( $\mathrm{cf}$. W. Koppen $\mathrm{cfb}$ ), sendo que as temperaturas médias mensais oscilam entre 12,9 ôC, em julho, e 26,6 ôC, em janeiro, podendo de maio a outubro ocorrer a formação de geadas. Todavia, raramente se verificam nevadas. As chuvas na regiå se distribuem por todo o ano, perfazendo um total médio correspondente a $1967 \mathrm{~mm}$, sendo que, em média, atingem 278 
mm em janeiro, decrescendo até $95 \mathrm{~mm}$ em julho.

Os valores médios, referentes à precipitação pluvial, temperatura (mínima, média e máxima) e umidade relativa evidenciados na área experimental, no período entre 1979 a 1992, são apresentados na Tabela 1.

\subsection{Característica da área experimental}

3.2.1. Solo

o solo da área experimental foi classificado como pertencente à Associação Bruno Álico + Cambissolo (EMPRESA BRASILEIRA DE PESQUISA AGROPECUARIA, 1984), cujas características químicas, são apresentados na Tabela 2, segundo metodologia descrita por TEDESCO et al. (1985).

\subsubsection{Parcelas experimentais}

Foram utilizadas parcelas com 10 m de
comprimento e $6 \mathrm{~m}$ de largura, perfazendo uma área total de 60
$\mathrm{~m}^{2}$. Como bordadura lateral, foram semeadas uma a duas linhas,
conforme a espécie em cultivo. Como bordadura nas
extremidades da parcela, foram cultivadas aveia branca ou
ervilhaca no inverno e soja no verão.


Tabela 1. Dados relativos à precipitação pluvial (PP) (1979 a 1992), temperatura (T) mínima (mín.), média (méd.) e máxima (máx.) ( 1980 a 1992) e umidade relativa (UR) (1981 a 1992), na Cooperativa Agrária Mista Entre Rios Ltda., Guarapuava, PR.

\begin{tabular}{|c|c|c|c|c|c|c|c|c|c|c|c|c|c|}
\hline & & & & & & $M \hat{e}$ & & & & & & & \\
\hline & $\mathrm{Jan}$ & Fev: & Mar & $\mathrm{Abr}$ & $\mathrm{Ma} \mathrm{i}$ & Jun & $\mathrm{Ju} \mathrm{l}$ & Ago & Set & Out & Nov & $\overline{\operatorname{Dez}}$ & \\
\hline PP & & & & & & & $\mathrm{mm}$ & & • & & & & Total \\
\hline $79-89$ & 168 & 176 & 115 & 149 & 224 & 133 & 165 & 102 & 143 & 194 & 190 & 206 & 1965 \\
\hline 1990 & 361 & 59 & 99 & 229 & 102 & 169 & 186 & 174 & 218 & 291 & 126 & 122 & 2136 \\
\hline 1991 & 130 & 73 & 190 & 180 & 46 & 308 & 28 & 82 & 44 & 280 & 156 & 259 & 1776 \\
\hline 1992 & 164 & 157 & 144 & 125 & 579 & 122 & & & & & & & \\
\hline $\begin{array}{l}T \\
80-89\end{array}$ & . & & & & & & ${ }^{\circ} \mathrm{C}$ & & & & & & Média \\
\hline mín. & 16 & 17 & 15 & 14 & 11 & 8 & 9 & 10 & 10 & 12 & 14 & 16 & 13 \\
\hline méd & 21 & 21 & 20 & 18 & 15 & 13 & 12 & 14 & 15 & 17 & 20 & 20 & 17 \\
\hline $\operatorname{mudx}$ & 28 & 26 & 26 & 24 & 21 & 19 & 19 & 21 & 22 & 24 & 26 & 26 & 24 \\
\hline 1990 & & & & & & & & & & & & & \\
\hline mín. & 17 & 15 & 16 & 15 & 9 & 8 & 6 & 8 & 9 & 14 & 16 & 15 & 12 \\
\hline méd. & 20 & 20 & 20 & 19 & 13 & 11 & 10 & 13 & 13 & 18 & 20 & 20 & 16 \\
\hline máx & 24 & 26 & 26 & 25 & 19 & 18 & 15 & 19 & 19 & 24 & 26 & 26 & 22 \\
\hline 1991 & & & & & & & & & & & & & \\
\hline mín. & 15 & 14 & 15 & 13 & 11 & 10 & 8 & 10 & 11 & 13 & 14 & 16 & 13 \\
\hline méd. & 20 & 19 & 19 & 17 & 15 & 14 & 12 & 14 & 15 & 17 & 19 & 20 & 17 \\
\hline máx. & 27 & 27 & 25 & 24 & 21 & 19 & 19 & 20 & 22 & 23 & 26 & 26 & 23 \\
\hline 1992 & & & & & & & & & & & & & \\
\hline mín. & 15 & 17 & 16 & 13 & 12 & 12 & & & & & & & \\
\hline méd. & 20 & 20 & 19 & 16 & 15 & 15 & & & & & & & \\
\hline máx. & 26 & 27 & 24 & 22 & 20 & 20 & & & & & & & \\
\hline UR & & & & & & & $\%$ & & & & & & Média \\
\hline $81-89$ & 77 & 81 & 80 & 80 & 79 & 79 & 79 & 78 & 78 & 75 & 73 & 78 & 78 \\
\hline 1990 & 91 & 81 & 86 & 84 & 81 & 83 & 88 & 79 & 77 & 81 & 81 & 76 & 82 \\
\hline 1991 & 76 & 74 & 84 & 85 & 83 & 84 & 76 & 81 & 78 & 81 & 70 & 80 & 79 \\
\hline 1992 & 80 & 85 & 89 & 84 & 88 & 86 & & & & & & & \\
\hline
\end{tabular}


Tabela 2. Valores de pH, alumínio (trocável), cálcio + magnésio (trocável), fósforo (extraível), potássio (trocável) e matéria orgânica do solo, relativo à área experimental por ocasião do inicio do ensaio, maio de 1984.

\begin{tabular}{|c|c|c|c|c|c|}
\hline $\begin{array}{c}\mathrm{pH} \\
\text { (água ) }\end{array}$ & $\begin{array}{c}\text { Al } \\
(\mathrm{meq} / \\
100 \mathrm{~g} \\
\text { solo) }\end{array}$ & $\begin{array}{c}C a+M g \\
(\text { meq } / \\
100 g \\
\text { solo })\end{array}$ & $\begin{array}{l}P \\
(\mathrm{ppm})\end{array}$ & $\begin{array}{l}\mathrm{K} \\
(\mathrm{ppm})\end{array}$ & $\begin{array}{l}\text { Matéria } \\
\text { orgânica } \\
(\%)\end{array}$ \\
\hline 5,1 & 0,4 & 8,0 & 5,7 & 78 & 6,8 \\
\hline
\end{tabular}

Os quatros sistemas de rotaçăo, estudados para trigo foram constituidos de dez (10) parcelas, objetivando avaliar o efeito do ano, quais sejam:

1) sistema para trigo, com uma parcela: monocultura de trigo/soja;

2) sistema para trigo, com duas parcelas: trigo/soja e aveia/soja; aveia/soja e trigo/soja;

3) Sistema para trigo, com três parcelas: trigo/soja, ervilhaca/milho e aveia/soja; ervilhaca/milho, aveia/soja e trigo/soja; aveia/soja, trigo/soja e ervilhaca/milho;

4) sistema para trigo, com quatro parcelas: trigo/soja, ervilhaca/milho, cevada/soja e aveia/soja; ervilhaca/milho, cevada/soja, aveia/soja e trigo/soja; cevada/soja, aveia/soja, trigo/soja e ervilhaca/milho; aveia/soja, trigo/soja, ervilhaca/milho e cevada/soja; 
Por sua vez, os quatro sistemas de rotação para trigo, possibilitaram comparar cada espécie, quanto ao, rendimento de grãos (aveia, cevada, milho, soja e trigo) ou para cobertura verde (ervilhaca). Além disso, os sistemas de rotação mencionados para trigo, permitiram, também, estudar sistemas de rotação para milho e soja, conforme observado na Tabela 3 .

Tabela 3. Sistemas de rotação para trigo com culturas de inverno e de verão, em plantio direto. Cooperativa Agrária Mista Entre Rios Ltdä, Guarapuava, PR, 1984 a 1992.

\begin{tabular}{|c|c|c|c|c|c|c|c|c|}
\hline \multirow{2}{*}{$\begin{array}{l}\text { Sistemas } \\
\text { de } \\
\text { rotação }\end{array}$} & \multicolumn{7}{|c|}{ Ano } & \multirow[b]{2}{*}{1991} \\
\hline & 1984 & 1985 & 1986 & 1987 & 1988 & 1989 & 1990 & \\
\hline Monocultura de trigo & $\mathrm{T} / \mathrm{S}$ & $\mathrm{T} / \mathrm{S}$ & $\mathrm{T} / \mathrm{S}$ & $\mathrm{T} / \mathrm{S}$ & $\mathrm{T} / \mathrm{S}$ & $\mathrm{T} / \mathrm{S}$ & $\mathrm{T} / \mathrm{S}$ & $\mathrm{T} / \mathrm{S}$ \\
\hline $\begin{array}{l}\text { Rotação, com um } \\
\text { inverno sem trigo }\end{array}$ & $\begin{array}{l}\mathrm{T} / \mathrm{S} \\
\mathrm{E} / \mathrm{M}\end{array}$ & $\begin{array}{l}\mathrm{E} / \mathrm{M} \\
\mathrm{T} / \mathrm{S}\end{array}$ & $\begin{array}{l}\mathrm{T} / \mathrm{S} \\
\mathrm{E} / \mathrm{M}\end{array}$ & $\begin{array}{l}\mathrm{E} / \mathrm{M} \\
\mathrm{T} / \mathrm{S}\end{array}$ & $\begin{array}{l}\mathrm{T} / \mathrm{S} \\
\mathrm{E} / \mathrm{M}\end{array}$ & $\begin{array}{l}\mathrm{E} / \mathrm{M} \\
\mathrm{T} / \mathrm{S}\end{array}$ & $\begin{array}{l}\mathrm{T} / \mathrm{S} \\
\mathrm{A} / \mathrm{S}\end{array}$ & $\begin{array}{l}\mathrm{A} / \mathrm{S} \\
\mathrm{T} / \mathrm{S}\end{array}$ \\
\hline $\begin{array}{l}\text { Rotação, com dois } \\
\text { invernos, sem trigo }\end{array}$ & $\begin{array}{l}\mathrm{T} / \mathrm{S} \\
\mathrm{L} / \mathrm{S} \\
\mathrm{E} / \mathrm{M}\end{array}$ & $\begin{array}{l}\mathrm{L} / \mathrm{S} \\
\mathrm{E} / \mathrm{M} \\
\mathrm{T} / \mathrm{S}\end{array}$ & $\begin{array}{l}E / M \\
T / S \\
L / S\end{array}$ & $\begin{array}{l}\mathrm{T} / \mathrm{S} \\
\mathrm{L} / \mathrm{S} \\
\mathrm{E} / \mathrm{M}\end{array}$ & $\begin{array}{l}\mathrm{L} / \mathrm{S} \\
\mathrm{E} / \mathrm{M} \\
\mathrm{T} / \mathrm{S}\end{array}$ & $\begin{array}{l}\mathrm{E} / \mathrm{M} \\
\mathrm{T} / \mathrm{S} \\
\mathrm{L} / \mathrm{S}\end{array}$ & $\begin{array}{l}\text { T/S } \\
\text { E/M } \\
\mathrm{A} / \mathrm{S}\end{array}$ & $\begin{array}{l}\mathrm{E} / \mathrm{M} \\
\mathrm{A} / \mathrm{S} \\
\mathrm{T} / \mathrm{S}\end{array}$ \\
\hline $\begin{array}{l}\text { Rotação, com três } \\
\text { invernos, sem trigo }\end{array}$ & $\begin{array}{l}\mathrm{T} / \mathrm{S} \\
\mathrm{A} / \mathrm{S} \\
\mathrm{C} / \mathrm{S} \\
\mathrm{Tr} / \mathrm{M}\end{array}$ & $\begin{array}{l}\mathrm{A} / \mathrm{S} \\
\mathrm{C} / \mathrm{S} \\
\mathrm{Tr} / \mathrm{M} \\
\mathrm{T} / \mathrm{S}\end{array}$ & $\begin{array}{l}\mathrm{C} / \mathrm{S} \\
\mathrm{Tr} / \mathrm{M} \\
\mathrm{T} / \mathrm{S} \\
\mathrm{A} / \mathrm{S}\end{array}$ & $\begin{array}{l}\mathrm{Tr} / \mathrm{M} \\
\mathrm{T} / \mathrm{S} \\
\mathrm{A} / \mathrm{S} \\
\mathrm{C} / \mathrm{S}\end{array}$ & $\begin{array}{l}\mathrm{T} / \mathrm{S} \\
\mathrm{A} / \mathrm{S} \\
\mathrm{C} / \mathrm{S} \\
\mathrm{Tr} / \mathrm{M}\end{array}$ & $\begin{array}{l}\mathrm{A} / \mathrm{S} \\
\mathrm{C} / \mathrm{S} \\
\mathrm{Se} / \mathrm{M} \\
\mathrm{T} / \mathrm{S}\end{array}$ & $\begin{array}{l}\mathrm{C} / \mathrm{S} \\
\mathrm{A} / \mathrm{S} \\
\mathrm{T} / \mathrm{S} \\
\mathrm{E} / \mathrm{M}\end{array}$ & $\begin{array}{l}\mathrm{A} / \mathrm{S} \\
\mathrm{T} / \mathrm{S} \\
\mathrm{E} / \mathrm{M} \\
\mathrm{C} / \mathrm{S}\end{array}$ \\
\hline
\end{tabular}

A: aveia, C: cevada, E: ervilhaca, L: linho, M: milho, Se: serradela, S: soja, Tr: tremoço e T: trigo 
3.2.3. Correção da acidez do solo

A acidez do solo foi corrigida em duas oportunidades, antes da semeadura das culturas de inverno em 1984 (Tabela 2). com 3,7 t/ha de calcário (PRNT=75\%) e em 1989 (Tabela 4), com 11,7 t./ha de calcário (PRNT=75\%), ambas com dose necessária para elevar o pH até 6,0. Salienta-se que, no último ano, em função da dose elevada, o calcário foi aplicado em duas épocas, uma antes da aração (arado de disco) e a outra antecedendo a gradeação da área (grade pesada ou grade aradora).

Tabela 4. Valores de pH, alumínio (trocável), cálcio t magnésio (trocável), fósforo (extraivel), potássio (trocável) e matéria orgânica do solo, relativo à área experimental após as culturas de verão, em 1989 e antes da aplicação de calcário.

\begin{tabular}{cccccc}
\hline $\begin{array}{c}\mathrm{pH} \\
(\text { água } 1: 1)\end{array}$ & $\begin{array}{c}\mathrm{Al} \\
(\mathrm{meq} \\
100 \mathrm{~g} \\
\text { solo })\end{array}$ & $\begin{array}{c}\mathrm{Ca}+\mathrm{Mg} \\
(\mathrm{meq} \\
100 \mathrm{~g} \\
\text { solo) }\end{array}$ & $\begin{array}{c}\mathrm{P} \\
(\mathrm{ppm})\end{array}$ & $\begin{array}{c}\text { Matéria } \\
(\mathrm{ppm})\end{array}$ & $\begin{array}{c}\text { orgânica } \\
(\%)\end{array}$ \\
\hline 4,7 & 2,5 & 7,4 & 14,0 & 164 & 7,5 \\
\hline
\end{tabular}




\subsubsection{Amostragem do solo}

No ano de 1991, foram coletadas amostras de solo após as culturas de inverno, em quatro profundidades: 0$5 \mathrm{~cm}, 5-10 \mathrm{~cm}, 10-15 \mathrm{~cm}$ e $15-20 \mathrm{~cm}$ (quatro subamostras por parcela), com a finalidade de se verificar o efeito da correção e dos sistemas de rotação adotados.

As análises químicas realizadas ( $\mathrm{pH}$ em água, a lumínio trocável, cálcio + magnésio trocáveis, fósforo extraível, potássio trocável e matéria orgânica), seguirama metodologia descrita por TEDESCO et al. (1985) e foram efetuadas no Laboratório de Análise do Solo da EMBRAPA/CNPT.

\subsubsection{Culturas usadas no experimento}

\subsubsection{Aveia (Avena sativa L.)}

A aveia foi estabelecida em plantio direto, através de semeadora Semeato-modelo TD-300 de disco duplo, empregando-se os cultivares UPF 7 (1990) e UPF 5 (1991), sobre os residuos de milho e de soja. Para tanto, foi utilizado o espaçamento de 0,17 m entre linhas e 300 sementes aptas por $\mathrm{m}^{2}$. A adubação de manutenção foi de $180 \mathrm{~kg} / \mathrm{ha}$, da fórmula 8-30-20, em 1990, e $110 \mathrm{~kg} / \mathrm{ha}$, da fórmula 5-25-25, em 1991. Na época recomendada foi realizada a adubação 
nitrogenada de cobertura, aplicando-se $20 \mathrm{~kg} / \mathrm{ha}$ (1990) e 30 $\mathrm{kg} / \mathrm{ha}$ de nitrogênio, na forma de uréia.

\subsubsection{Cevada (Hordeum vulgare L.)}

A cevada foi implantada com a mesma semeadora utilizada para a aveia, empregando-se os cultivares Antartica 5 (1990) e BR 2 (1991), sobre os residuos de milho e de soja. Na semeadura foram utilizadas 300 sementes aptas por $\mathrm{m}^{2}$. obederende cspacamento do $0,17 \mathrm{~m}$ ontro linhas. A adubacaro de manutençao foi de $234 \mathrm{~kg} / \mathrm{ha}$, da fórmula 8-30-20, em 1990 e $220 \mathrm{~kg} / \mathrm{ha}$, da fórmula 5-25-25, em 1991. A adubação nitrogenada de cobertura, foi efetuada na época indicada, aplicando-se $30 \mathrm{~kg} / \mathrm{ha}$ (1990) e $20 \mathrm{~kg} / \mathrm{ha}$ (1991), de nitrogênio na forma de uréia.

\subsubsection{Ervilhaca (Vicia sativa L.)}

A ervilhaca foi estabelecida sobre o residuo de soja. As sementes receberam inoculante especifico e não usouse adubação de manutenção. O plantio foi feito com a mesma semeadora utilizada para a aveia. O espaçamento usado foi de $0,17 \mathrm{~m}$ entre linhas, semeando-se 50 sementes aptas por $\mathrm{m}^{2}$. 
3.2.5.4. Milho (Zea mays L.)

o milho foi implantado sob o sistema plantio direto, mediante uso de semeadora de disco duplo da Semeato, modelo PAR 2800, utilizando-se o cultivar hibrido Pioneer 3072 (em 1990 e 1991), após a cultura de ervilhaca. Utilizouse o espaçamento de $0,90 \mathrm{~m}$ entre linhas e 6 sementes por metro, objetivando uma população final de 5 plantas/m. A adubação de manutenção foi de $300 \mathrm{~kg} / \mathrm{ha}$, da fórmula 5-25-25, em 1990 e $290 \mathrm{~kg} / \mathrm{ha}$, da fórmula 8-30-20, em 1991. Cumpre ressaltar que nessa cultura năo foi realizada a adubação nitrogenada de cobertura, em funça da presença de resíduo de loguminosia, oriunda la osperio anterior.

\subsubsection{Soja (Glycine $\max$ L.)}

A soja foi estabelecida após a cultura de aveia ou cevada e de trigo, em plantio direto, com semeadora de disco duplo, Semeato modelo PAR 2800, usando cultivar IAS 5 (em 1990 e 1991). As sementes foram previamente tratadas com inoculante especifico. O espaçamento usado foi correspondente a 0,40 m entre linhas com 25 sementes por metro, objetivando assegurar uma população final de 20 plantas/m. A adubação de manutenção foi de $250 \mathrm{~kg} / \mathrm{ha}$, da fórmula 2-20-20 (em 1990 e 1991). 
3.2.5.6. Trigo (Triticum aestivum L.)

O trigo foi implantado em plantio direto, após a soja, com a mesma semeadora utilizada na cultura da aveia, empregando-se o cultivar. BR 23 (em 1990 e 1991). Foram semeadas 320 sementes aptas por $\mathrm{m}^{2}$, obedecendo o espaçamento de $0,17 \mathrm{~m}$ entre linhas. A adubação de manutenção foi de $234 \mathrm{~kg} / \mathrm{ha}$, em 1990 e $210 \mathrm{~kg} / \mathrm{ha}$, em 1991, da fórmula 8-30-20. $\mathrm{Na}$ época recomendada foi efetuada a adubação nitrogenada de cobertura, aplicando-se $30 \mathrm{~kg} / \mathrm{ha}$ de uréia (em 1990 e 1991).

\subsubsection{Adubação e tratos culturais}

A adubação de manutenção foi realizada de acordo com a recomendação para cada cultura, baseando-se no resultado de análise do solo, sendo que as amostras foram coletadas, logo após as culturas de inverno ou de verão.

Da mesma forma, as épocas de semeadura, o controle de plantas daninhas e os tratamentos fitossanitários, inclusive o tratamento de semente de cevada e de trigo, foram realizados de acordo com a recomendaçăo básica para cada cultura, sendo a colheita executada com automotriz especial para parcelas, marca Hege $125 \mathrm{C}$, adaptada com picador de palha. 
3.3. Parâmetros avaliados

3.3.1. Rendimento de grãos de aveia, de cevada, de milho, de soja e de trigo

O rendimento de grãos, no caso de milho, foi aquele proveniente da colheita das cinco linhas centrais, deixando-se $1,0 \mathrm{~m}$ nas extremidades da parcela como bordadura; enquanto que o de aveia, de cevada, de soja e de trigo oriundos de toda a área colhida da parcela experimental. Para todas as espécies, a umidade de grãos foi corrigida para $13 \%$.

3.3.2. Intensidade de doenças do sistema radicular do trigo

A avaliação do grau de intensidade (GI) das doenças do sistema radicular do trigo (Gaeumannomyces graminis var. tritici e Bipolaris sorokinianal foi procedida de acordo com o método utilizado por REIS et al. (1985), cujos dados foram transformados em arcoseno $\sqrt{\mathrm{x}} \mathrm{visando} a$ melhor interpretação dos resultados. 


\subsubsection{Análise do balanço energético dos sistemas de rotação para trigo}

$\mathrm{Na}$ conversão dos sistemas de rotação para o trigo em unidades energéticas foi utilizado um indice adaptado de HEICHEL (1980), PIMENTEL (1980a), FELIPPE JUNIOR (1984) e MELLO (1986). O referido indice leva em consideração a razão entre o rendimento de grãos de cada espécie em estudo e a energia cultural, representada pelo uso de insumos e atividades de operacionalização do sistema de produção. Este Indice é denominado "Produtividade cultural", sendo representado pela seguinte equação:

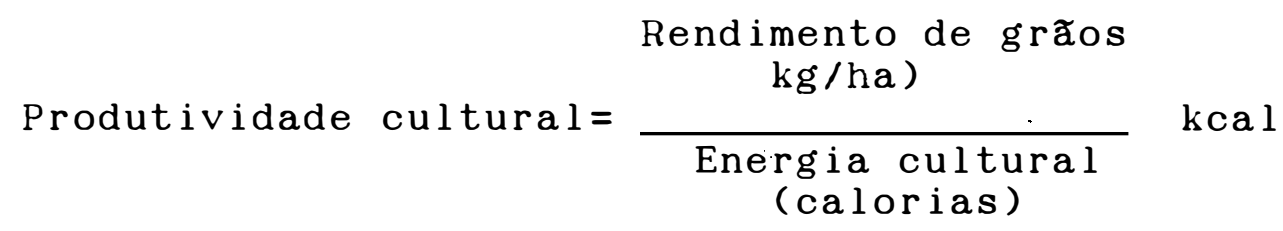

Caloria (cal) é definida como a quantidade de calor necessária para elevar de $14,5^{\circ} \mathrm{C}$ a $15,5^{\circ} \mathrm{C}$ à temperatura de uma grama de água. A correspondente como unidade de energia utilizada no sistema internacional é 1 cal $=4,186 \mathrm{~J}$ (joule $) ; 1 \mathrm{kcal}=10^{3} \mathrm{cal}$ e $1 \mathrm{Mcal}=10^{6} \mathrm{cal}$. 


\subsubsection{Análise econômica dos sistemas de rotaçåo para trigo}

A análise econômica empregada no presente trabalho, obedeceu a metodologia proposta por NEVES \& SHIROTA (1986) e A:DiA et al. (1991). Cumpre ressaltar que os custos dos insumos e das operaços de campo (semeadura, tratos culturais e colheita), bem como o preço de venda dos produtos obtidos, foram convertidos para moeda americana (US\$), utilizando como valor base aquele correspondente ao mês de maio de 1992 (US\$ 1: CR\$ 2.849,25).

\section{4. Delineamento experimental}

O delineamento experimental adotado foi de blocos ao acaso, com quatro repetiçðes.

Para a interpretação dos resultados foi realizada a análise da variância individual e conjunta para as características agronômicas de milho, de soja e de trigo, sendo as médias comparadas entre si, pela aplicação do teste de Duncan ao nível de 5\% de probabilidade, conforme observado nas Tabelas 5 e 6 .

Os efeitos dos diversos sistemas de cultivo sobre as propriedades do solo, foram avaliadas através da análise da variância, mediante análises individuais para cada profundidade de amostragem de solo (Tabela 5). Da mesma 
forma, as médias foram comparadas entre si, pela aplicação do teste de Duncan, ao nível de $5 \%$ de probabilidade.

Tabela 5. Análise da variância individual dos dados de renmento de grãos (milho, soja e trigo), da intencidade de doencas do sistema radicular de trigo e das propriedades de solo para cada profundidade do mesmo.

\begin{tabular}{lcccccc}
\hline & \multicolumn{3}{c}{ G. L. } & Q.M. & F \\
\cline { 3 - 5 } Causas da variaço & milho soja trigo & & \\
\hline Blocos & 3 & 3 & 3 & V1 & V \\
Tratamentos & 1 & 7 & 3 & V2 & V2/V3 \\
Residuo & 3 & 21 & 9 & V3 & \\
\hline Total & 7 & 31 & 15 & & \\
\hline
\end{tabular}

Tabela 6. Análise da variância conjunta dos dados de rendimento (milho, soja e trigo) e da incidência das doenças do sistema radicular do trigo.

\begin{tabular}{lcccccc}
\hline & \multicolumn{3}{c}{ G.L. } & Q.M. & $F$ \\
\cline { 3 - 4 } Causas da variação & milho soja trigo & & \\
\hline & 1 & 1 & 1 & V1 & V1/V3 \\
Anos & 1 & 7 & 3 & V2 & V2/V3 \\
Tratamentos & 1 & 7 & 3 & V3 & V3/V4 \\
Anos x tratamentos & & & 18 & V4 & \\
Residuo médio & & & & & \\
\hline
\end{tabular}


4. RESULTADOS

4.1. Rendimento de grãos de aveia, de cevada, de milho, de soja e do trigo e intensidade das doenças do sistema radicular do trigo

Os rendimentos de grãos de aveia, de cevada, de milho, de soja e de trigo, obtidos no período de 1990 a 1991 , nos diversos sistemas de rotação para trigo, em plantio direto, podem ser observados na Tabela 7 .

A seguir são apresentados a análise conjunta dos dados para o rendimento de grãos de milho, de soja e de trigo, bem como a intensidade das doenças do sistema radicular do trigo.

Os dados do rendimento de grãos de milho, nos dois (2) sistemas de rotação, em plantio direto, no período agrícola 1990/1991 e 1991/1992, podem ser observados na Tabela 8 .

Na Tabela 9, encontram-se os rendimentos de grãos da soja, nos oito (8) sistemas de rotação, em plantio direto, realizada no período de 1990/1991 e 1991/1992.

Os resultados da intensidade das doenças do sistema radicular (mal-do-pé e podridão comum) e do 
Tabela 7. Efeito de sistemas de rotação para trigo com culturas de inverno e de verão, de 1990 e 1991, em plantio direto.

\begin{tabular}{|c|c|c|c|c|}
\hline \multirow{3}{*}{ Sistemas de rotação } & \multicolumn{4}{|c|}{ Ano } \\
\hline & \multicolumn{2}{|c|}{$1990 / 1991$} & \multicolumn{2}{|c|}{$1991 / 1992$} \\
\hline & inverno & verão & inverno & verão \\
\hline & \multicolumn{4}{|c|}{$\ldots \ldots \ldots \ldots$ kg/ha $\ldots \ldots \ldots \ldots$} \\
\hline Monocultura de trigo & $\begin{array}{l}\text { Trigo } \\
3.152\end{array}$ & $\begin{array}{l}\text { So.ja } \\
3.996\end{array}$ & $\begin{array}{l}\operatorname{Tr} \mathrm{i} 80 \\
3.8314\end{array}$ & $\begin{array}{l}\text { So.ja } \\
3.046\end{array}$ \\
\hline$\cdots \cdots \cdots \cdots \cdots$ & $\cdots \cdots \cdots$ & $\cdots \cdots$ & $\cdots \cdots \cdots$ & $\cdots \cdots$ \\
\hline \multirow[t]{2}{*}{$\begin{array}{l}\text { Rotação, } \quad \text { rom } \\
\text { inverno } \\
\text { sem t.rigo }\end{array}$} & $\begin{array}{l}\text { Trigo } \\
3.583\end{array}$ & $\begin{array}{l}\text { So.ja } \\
4.085\end{array}$ & $\begin{array}{l}\text { Ave ia } \\
3.232\end{array}$ & $\begin{array}{l}\text { Soja } \\
3.210\end{array}$ \\
\hline & $\begin{array}{l}\text { Ave ia } \\
2.703\end{array}$ & $\begin{array}{l}\text { So.ja } \\
4.120\end{array}$ & $\begin{array}{l}\text { Trigo } \\
3.973\end{array}$ & $\begin{array}{l}\text { Soja } \\
3.051\end{array}$ \\
\hline 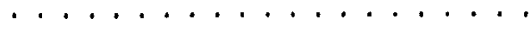 & $\ldots$ & $\cdots \cdots$ & $\cdots \cdots \cdots$ & $\cdots \cdots$ \\
\hline \multirow[t]{3}{*}{$\begin{array}{l}\text { Rotação, com dois } \\
\text { invernos sem trigo }\end{array}$} & $\begin{array}{l}\text { Trigo } \\
3.650\end{array}$ & $\begin{array}{l}\text { Soja } \\
4.081\end{array}$ & $\begin{array}{l}\text { Ervil haca } \\
*\end{array}$ & $\begin{array}{l}\text { Milho } \\
8.164\end{array}$ \\
\hline & $\underset{*}{\text { Ervi lhaca }}$ & $\begin{array}{l}\text { Milho } \\
3.238\end{array}$ & $\begin{array}{l}\text { Aveia } \\
2.697\end{array}$ & $\begin{array}{l}\text { Soja } \\
3.093\end{array}$ \\
\hline & $\begin{array}{l}\text { Ave i a } \\
2.920\end{array}$ & $\begin{array}{l}\text { So ja } \\
4.026\end{array}$ & $\begin{array}{l}\text { Trigo } \\
4.161\end{array}$ & $\begin{array}{l}\text { So ja } \\
3.089\end{array}$ \\
\hline \multirow[t]{4}{*}{$\begin{array}{l}\text { Rotação, com três } \\
\text { invernos sem trigo }\end{array}$} & $\begin{array}{l}\text { Cevada } \\
2.413\end{array}$ & $\begin{array}{l}\text { Soja } \\
4.021\end{array}$ & $\begin{array}{l}\text { Ave ia } \\
3.069\end{array}$ & $\begin{array}{l}\text { Soja } \\
2.900\end{array}$ \\
\hline & $\begin{array}{l}\text { Aveia } \\
2.878\end{array}$ & $\begin{array}{l}\text { Soja } \\
4.073\end{array}$ & $\begin{array}{l}\text { Trigo } \\
3.907\end{array}$ & $\begin{array}{l}\text { Soja } \\
3.031\end{array}$ \\
\hline & $\begin{array}{l}\text { Trigo } \\
3.666\end{array}$ & $\begin{array}{l}\text { So ja } \\
3.983\end{array}$ & $\underset{*}{\text { Ervil lhaca }}$ & $\begin{array}{l}\text { Milho } \\
8.110\end{array}$ \\
\hline & $\underset{*}{\text { Ervil haca }}$ & $\begin{array}{l}\text { Milho } \\
3.416\end{array}$ & $\begin{array}{l}\text { Cevada } \\
3.936\end{array}$ & $\begin{array}{l}\text { Soja } \\
3.322\end{array}$ \\
\hline
\end{tabular}

* Cultura para cobertura do solo no inverno e adubação verde durante verão. 
rendimento de grãos do trigo, dos quatro (4) sistemas de rotação de culturas, em plantio direto, no ano de 1990 e 1991, encontram-se nas Tabelas 10 e 11.

Tabela 8. Ffeito da ervilhaca no rendimento de grãos ( $\mathrm{kg} / \mathrm{ha}$ ) de milho de 1990 e 1991, cultivar híbrido Pioneer 3072, em plantio direto.

Sistemas de rotação $\quad \frac{\text { Ano }}{1990 / 1991}$ Média

$\ldots \ldots \ldots \ldots k g \ldots$

\begin{tabular}{|c|c|c|c|}
\hline Milho apos: & ervilhar:al & 3.233 & 8.164 \\
\hline & ervilhaca ${ }^{2}$ & 3.416 & 8.110 \\
\hline
\end{tabular}

Média

C. V. (\%)

F de tratamentos
3.327

7,85

$0,92 \mathrm{~ns}$
8. 137

$\begin{array}{ll}5,60 & - \\ 0,03 n s & 0,29 n s\end{array}$

Ervilhaca após trigo.

2Ervilhaca após, tremoço e trigo.

ns: não significativo. 
Tabela 9. Efeitos de culturas de inverno no rendimento de grãos (kg/ha) de soja de 1990 e 1991, cultivar IAC 5 , em plantio direto.

Sistema de rotação

$\frac{\text { Ano }}{1990 / 1991 \quad 1991 / 1992}$ Média

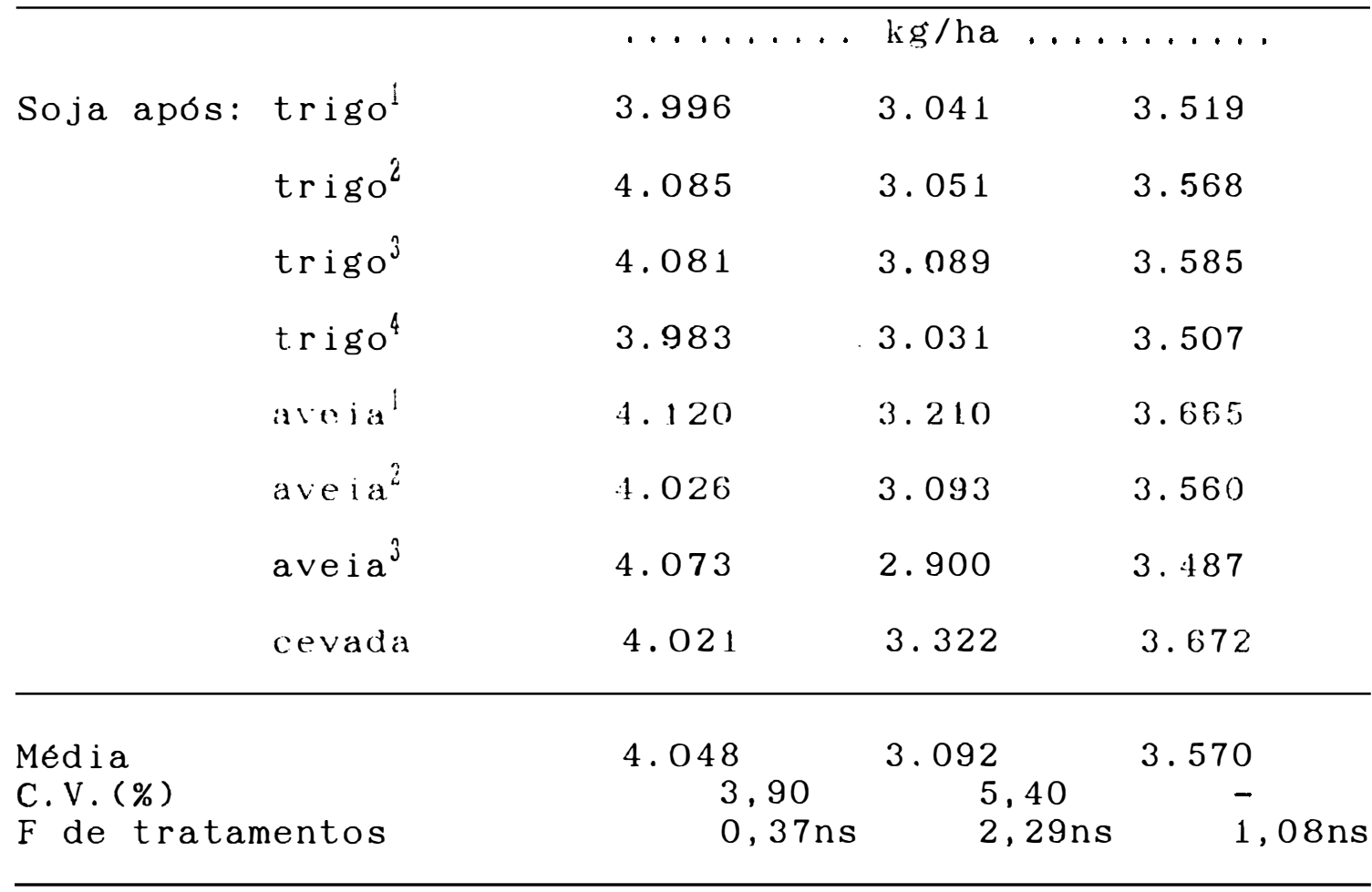

${ }_{2}^{1}$ Monocultura de trigo.

2Trigo após ervilhaca ou aveia.

${ }^{3}$ Trigo após linho e ervilhaca ou aveia.

4 Trigo após aveia, cevada ou serradela ou aveia.

${ }_{2}^{1}$ Aveia após trigo.

${ }_{3}^{2}$ Aveia após trigo, linho ou ervilhaca.

${ }^{3}$ Aveia após trigo, aveia e cevada.

ns: não significativo. 
Tabela 10. Efeitos de sistemas de rotação na intensidade de doenças do sistema radicular (\%) de trigo de 1990 e 1991, cultivar BR 23, em plantio direto.

Sistemas de rotaça

Médi a

$1990 \quad 1991$

$\ldots \ldots \ldots \ldots \ldots$

Monocultura de trigo $\quad 34,8 \mathrm{a} \quad 34,3 \mathrm{a} \quad 34,6$

Rotação, com um inverno sem trigo

$17,3 \mathrm{~b}$

$27,4 \mathrm{ab}$

22,4

Rotação, com dois

invernos sem trigo

$18,8 \mathrm{~b}$

$16,9 \mathrm{c}$

17,9

Rotação, com três
invernos sem trigo
$19,2 \mathrm{~b}$
$22,8 \mathrm{bc}$
21,0

Média

C. V. (\%)

F de tratamentos

$\begin{array}{llc}22,5 & 25,4 & 24,0 \\ 23,23 & 18,22 & - \\ 9,92 * * & 10,16 * * & 7,53 \mathrm{~ns}\end{array}$

Médias seguidas da mesma, letra na vertical, não apresentam diferenças significativas ao nível de 5\% de probabilidade, pelo teste de Ducan.

ns: não significativo.

**: nível de significância de $1 \%$. 
Tabela 11. Efeitos de sistemas de rotação no rendimento de grãos (kg/ha) de trigo de 1990 e 1991, cultivar BR 23, em plantio direto.

\begin{tabular}{|c|c|c|c|}
\hline \multirow{2}{*}{ Sistemas de rotação } & \multicolumn{2}{|l|}{ Ano } & \multirow{2}{*}{ Média } \\
\hline & 1990 & 1991 & \\
\hline & $\ldots \ldots$ & $\mathrm{kg} / \mathrm{ha} \ldots$ & $\ldots$ \\
\hline Monocultura de trigo & $3.152 \mathrm{~b}$ & 3.814 & 3.483 \\
\hline $\begin{array}{l}\text { Rotação, com um } \\
\text { inverno sem trigo }\end{array}$ & $3.583 a$ & 3.973 & 3.778 \\
\hline $\begin{array}{l}\text { Rotação, com dois } \\
\text { invernos sem trigo }\end{array}$ & $3.650 \mathrm{a}$ & 4. 161 & 3.906 \\
\hline $\begin{array}{l}\text { Rotação, com três } \\
\text { invernos sem trigo }\end{array}$ & $3.666 \mathrm{a}$ & 3.907 & 3.787 \\
\hline $\begin{array}{l}\text { Média } \\
\text { C.V. (\%) } \\
\text { F de tratamentos }\end{array}$ & $\begin{array}{r}3.513 \\
5,42 \\
6,51 *\end{array}$ & $\begin{array}{r}3.964 \\
6,86 \\
1,16 \mathrm{~ns}\end{array}$ & $\begin{array}{l}3.739 \\
\overline{4}, 03 \mathrm{~ns}\end{array}$ \\
\hline
\end{tabular}

Médias seguidas da mesma, letra na vertical, não apresentam diferenças significativas ao nivel de $5 \%$ de probabilidade, pelo teste de Duncan.

ns: não significativo.

*: nível de significância de $5 \%$.

4.2. Balanço energético dos sistemas de rotação para trigo

Os custos de utilização de insumos e de horas de operações de campo (semeadura, tratos culturais e colheita), bem como os rendimentos de grãos de cada espécie 
em estudo, no período de 1990 e 1991, foram convertidos para índices calóricos, tendo por fim o balanço energético dos sistemas de rotação para trigo, em plantio direto.

Os coeficientes técnicos das espécies relacjonados em unidades fisicas (insumos, semeadura, tratos (ulturats "rolnolla), bom como suas conversores a unidades energéticas, no ano de 1990 e 1991, estão apresentados nas Tabelas 2 a 6 , do Apêndice.

O Indice de produtividade cultural obtido nos sistemas de rotação para trigo em plantio direto, de 1990 e 1991, podem ser observados na Tabela 12.

Os efeitos de sistemas de rotação na produtividade cultural de 1990 e 1991, considerando os quatro sistemas de rotação para trigo ou aqueles envolvendo as culturas de aveia, de cevada e de trigo, no inverno, e de soja, no verão, estão mostrados nas Tabelas 13 e 14 .

4.3. Análise econômica dos sistemas de rotação para trigo

Os custos de uso dos insumos e das horas de operaçơes de campo (semeadura, tratos culturais e colheita), assim como os rendimentos de grãos de cada espécie, no período estudado, foram convertidos para valores monetários, visando a análise econômica dos sistemas de rotação para trigo, em plantio direto. 
Tabela 12. Produtividade cultural estimada (kg/Mcal) dos sistemas de rotação para trigo com culturas de inverno e de verão, de 1990 e 1991, em plantio direto.

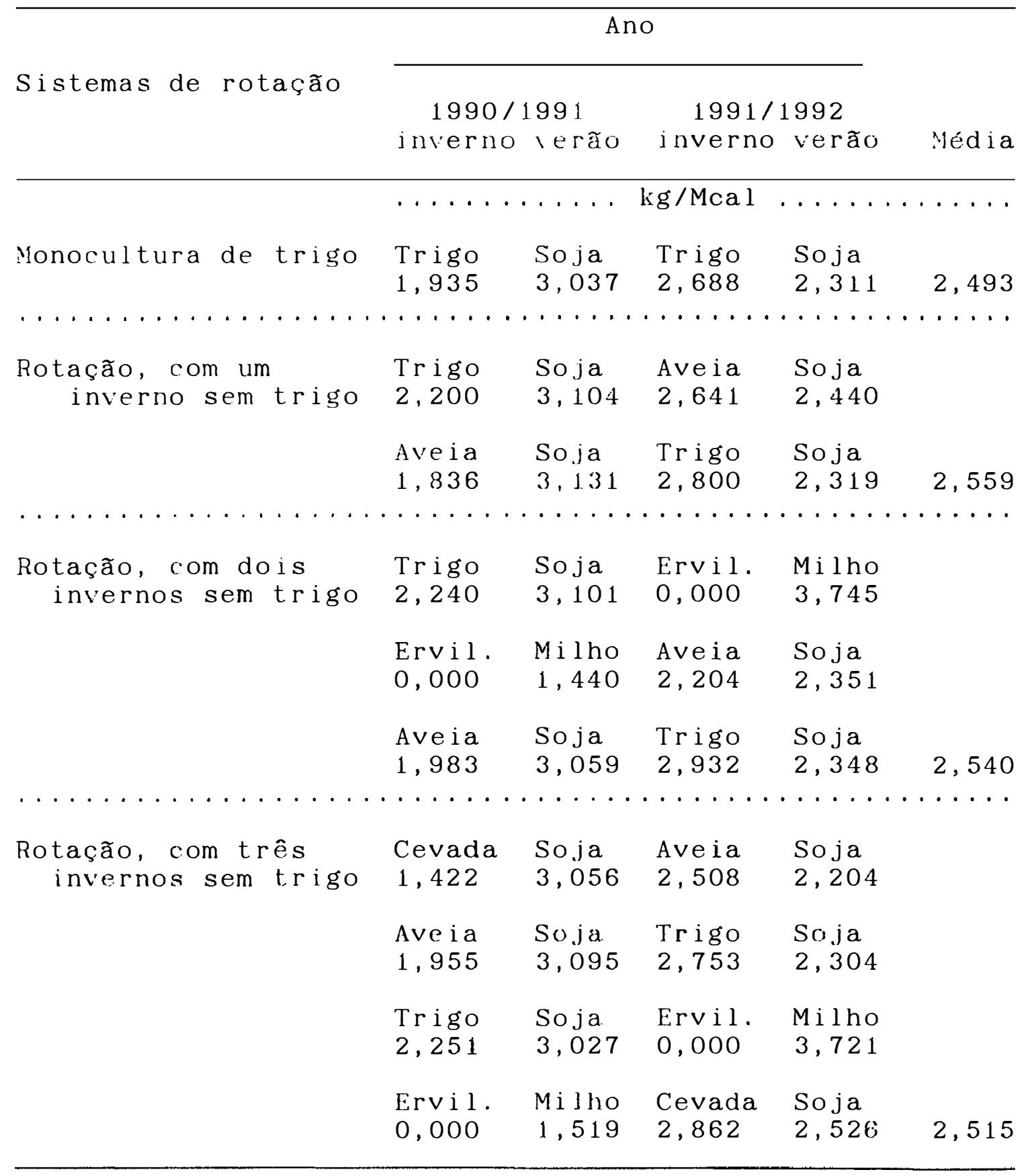

Ervil.: ervilhaca 
Tabela 13. Efeitos de sistemas de rotą̧a na produtividade cultural estimada (kg/Mcal) para trigo e soja, de 1990 e 1991, em plantio direto.

\begin{tabular}{|c|c|c|c|c|c|}
\hline \multirow{2}{*}{ Sistemas de rotaç ão } & \multicolumn{4}{|c|}{ Ano } & \multirow[b]{2}{*}{ Méd i a } \\
\hline & \multicolumn{2}{|c|}{$\begin{array}{c}1990 / 1991 \\
\text { inverno verão }\end{array}$} & \multicolumn{2}{|c|}{$1991 / 1992$} & \\
\hline & $\cdots \cdots$ & $\ldots \ldots$ & $\mathrm{kg} / \mathrm{Mcal}$ & $\ldots \ldots$ & \\
\hline Monocultura de trigo & $\begin{array}{l}\text { Trigo } \\
1,935 \mathrm{~b}\end{array}$ & $\begin{array}{l}\text { So ja } \\
3,037\end{array}$ & $\begin{array}{l}\text { Tr igo } \\
2,688\end{array}$ & $\begin{array}{l}\text { So ja } \\
2,311\end{array}$ & 2,493 \\
\hline $\begin{array}{l}\text { Rotação, com um } \\
\text { inverno sem trigo }\end{array}$ & $\begin{array}{l}\text { Trigo } \\
2,200 a\end{array}$ & $\begin{array}{l}\text { So ja } \\
3,104\end{array}$ & $\begin{array}{l}\text { Trigo } \\
2,800\end{array}$ & $\begin{array}{l}\text { So ja. } \\
2,319\end{array}$ & 2,606 \\
\hline $\begin{array}{l}\text { Rotação, com dois } \\
\text { invernos sem trigo }\end{array}$ & $\begin{array}{l}\text { Trigo } \\
2,240 a\end{array}$ & $\begin{array}{l}\text { So ja } \\
3,101\end{array}$ & $\begin{array}{l}\text { Tr iģo } \\
2,932\end{array}$ & $\begin{array}{l}\text { So ja } \\
2,348\end{array}$ & 2,655 \\
\hline $\begin{array}{l}\text { Rotacão, com três } \\
\text { invernos sem trigo }\end{array}$ & $\begin{array}{l}\text { Trigo } \\
2,251 \mathrm{a}\end{array}$ & $\begin{array}{l}\text { So ja } \\
3,027\end{array}$ & $\begin{array}{l}\text { Tr igo } \\
2,753\end{array}$ & $\begin{array}{l}\text { So ja } \\
2,304\end{array}$ & 2,584 \\
\hline $\begin{array}{l}\text { Média } \\
\text { C.V. (\%) } \\
\text { F de tratamentos }\end{array}$ & $\begin{array}{l}2,157 \\
5,52 \\
6,31 *\end{array}$ & $\begin{array}{l}3,067 \\
3,36 \\
0,64 \mathrm{~ns}\end{array}$ & $\begin{array}{l}2,793 \\
6,86 \\
1,17 \mathrm{~ns}\end{array}$ & $\begin{array}{l}2,320 \\
4,74 \\
0,13 \mathrm{~ns}\end{array}$ & $\begin{array}{l}2,585 \\
- \\
3,30 \mathrm{~ns}\end{array}$ \\
\hline
\end{tabular}

Médias seguidas da mesma, letra na vertical, não apresentam diferenças significativas ao nível de 5\% de probabilidade, pelo teste de Ducan.

*: nivel de significância de $5 \%$.

ns: năo significativo. 
Tabela 14. Efeitos de sistemas de rotação na produtividade cultural estimada ( $\mathrm{kg} /$ Mcal) para aveia, cevada e trigo, no inverno, e soja, no verão de 1990 e 1991, em plantio direto.

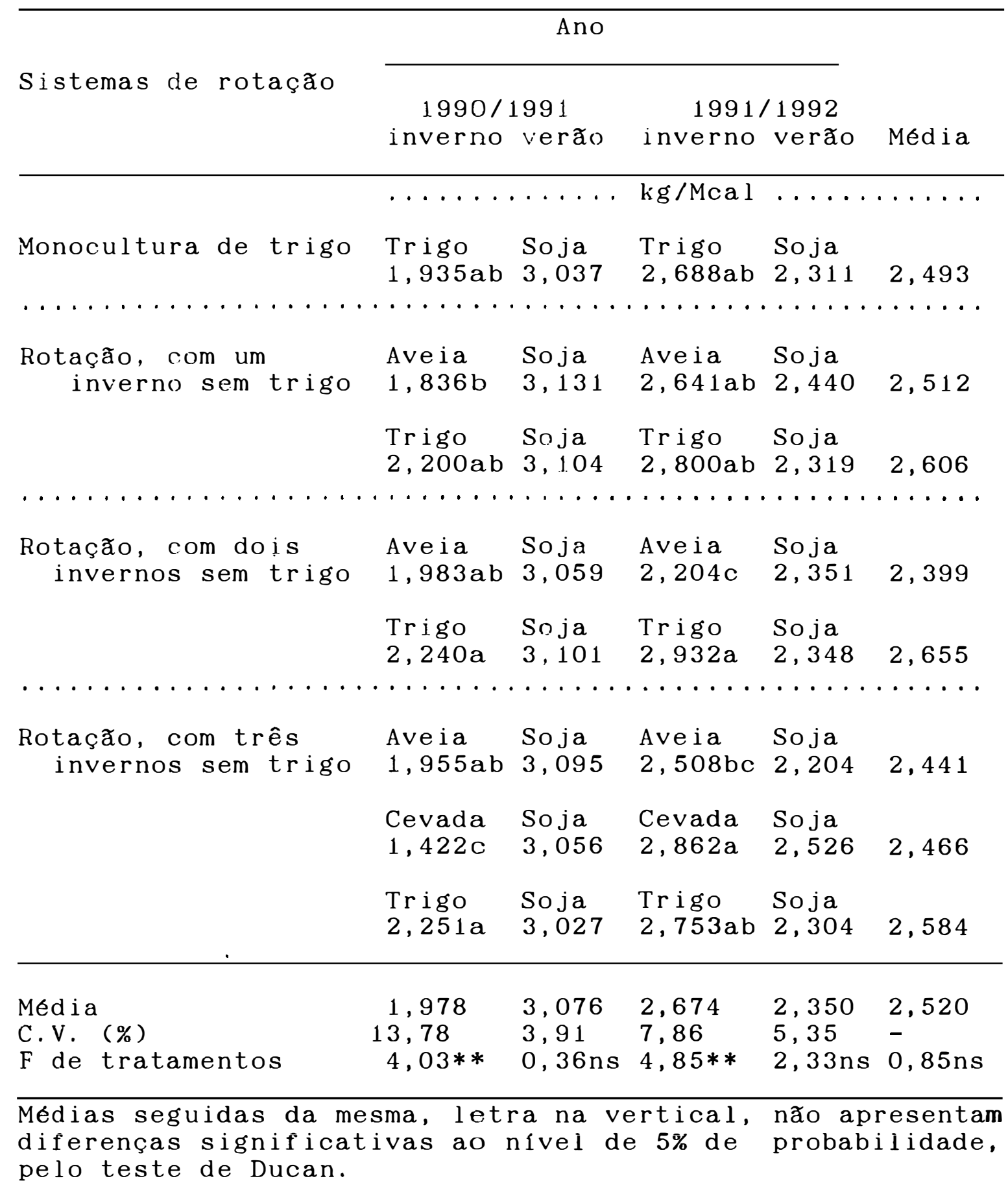

**: nível de significância de $1 \%$.

ns: não significativo. 
Os custos dos insumos e das operações de campo (semeadura, tratos culturais e colheita), dos sistemas de rotação para trigo, definidos por espécie, de 1990 e 1991 , encontram-se na Tabelas 15. O detalhamento dos custos dos insumos ( das operacooes de campo, por cultura, que participaram dos sistemas de rotacão para trigo, estão na Tabela 16.

A receita bruta e a receita liquida, dos sistemas de rotação para trigo em plantio direto, de 1990 e 1991, podem ser observados nas Tabelas 17 a 22 . Os dados relacionados a esses parâmetros, permitiram a comparação entre os quatro sistemas de cultivo para trigo (Tabelas 18 e 21) ou arrolando as culturas de aveia, de cevada e de trigo, no inverno e de soja, no verão (Tabelas 19 e 22), respectivamente. 
Tabela 15. Custo dos insumos e das operaçð̃es de campo dos sistemas de rotação para trigo com culturas de inverno e de verão, de 1990 e 1991, em plantio direto, em US\$ de maio de 1992 (US\$ 1: CR\$ 2.849,25).

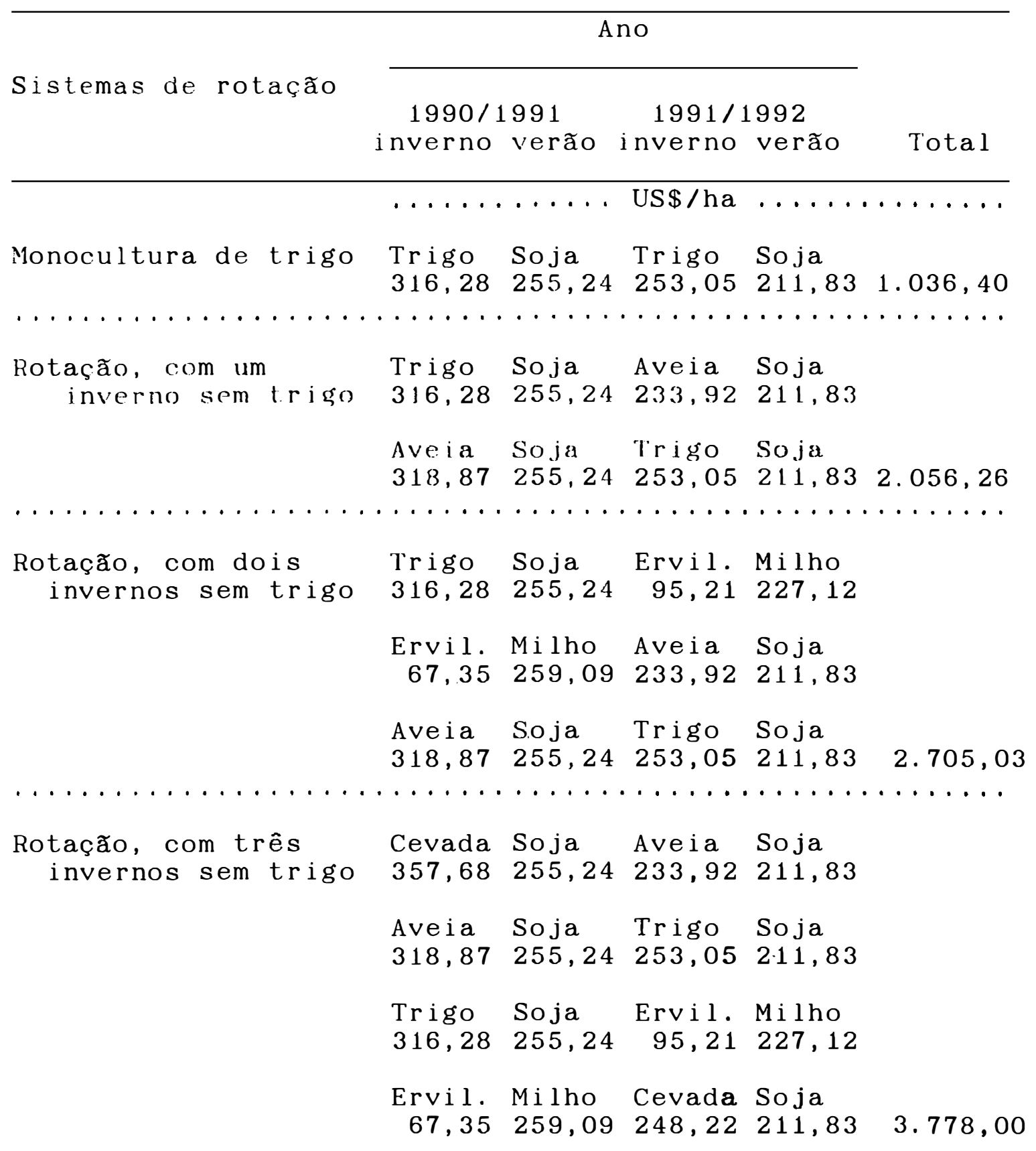

Ervil.: ervilhaca 
Tabela 16. Custo dos insumos e das operaçбes de campo por cultura que participaram dos sistemas de rotação para trigo, de 1990 e 1991, em plantio direto, em US\$ de maio de 1992 (US\$ 1: CRS 2.849,25).

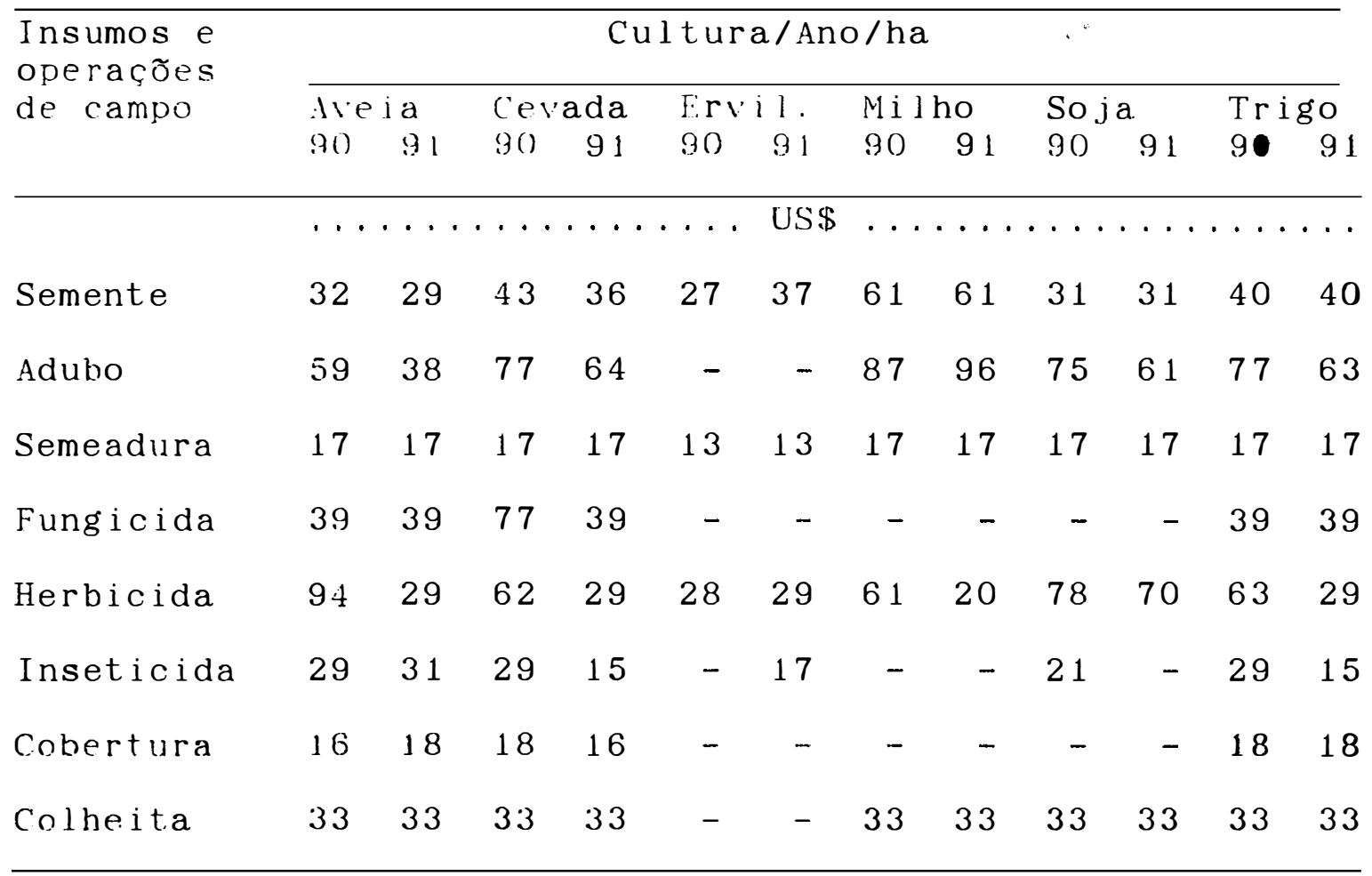

Custo total $319 \quad 234 \quad 356 \quad 249 \quad 68 \quad 96 \quad 259 \quad 227 \quad 255 \quad 212 \quad 316 \quad 254$

Ervil.: ervilhaca 
Tabela 17. Receita bruta dos sistemas de rotação para trigo com culturas de inverno e de verão, de 1990 e 1991, em plantio direto, em US\$ de maio de 1992 (US\$ 1: CR\$ 2.849,25).

\begin{tabular}{|c|c|c|c|c|c|}
\hline \multirow{2}{*}{ Sistemas de rotação } & \multicolumn{4}{|c|}{ Ano } & \multirow[b]{2}{*}{ Total } \\
\hline & \multicolumn{2}{|c|}{$1990 / 1991$} & \multicolumn{2}{|c|}{$1991 / 1992$} & \\
\hline Monocultura de trigo & $\begin{array}{l}\ldots \ldots \\
\text { Trigo } \\
472,80\end{array}$ & $\begin{array}{l}\ldots \ldots \\
\text { Soja } \\
719,28\end{array}$ & $\begin{array}{l}\text { US } \$ / \text { ha } \\
\text { Trigo } \\
572,10\end{array}$ & $\begin{array}{l}\ldots \ldots \\
\text { Soja } \\
547,38\end{array}$ & $2.311,56$ \\
\hline$\ldots \ldots \ldots \ldots \ldots$ & $\cdots \cdots$ & $\cdots \cdots$ & $\cdots \cdots$ & $\cdots \cdots$ & $\cdots \cdots \cdots$ \\
\hline $\begin{array}{l}\text { Rotação, com um } \\
\text { inverno sem trigo }\end{array}$ & $\begin{array}{l}\text { Trigo } \\
537,45\end{array}$ & $\begin{array}{l}\text { Soja } \\
735,30\end{array}$ & $\begin{array}{l}\text { Ave ia } \\
420,16\end{array}$ & $\begin{array}{l}\text { Soja } \\
577,80\end{array}$ & \\
\hline & $\begin{array}{l}\text { Ave ia } \\
351,39\end{array}$ & $\begin{array}{l}\text { Soja } \\
741.60\end{array}$ & $\begin{array}{l}\text { Trigo } \\
595,95\end{array}$ & $\begin{array}{l}\text { Soja } \\
549,18\end{array}$ & $4.508,83$ \\
\hline $\begin{array}{l}\text { Rotação, com dois } \\
\text { invernos sem trigo }\end{array}$ & $\begin{array}{l}\text { Trigo } \\
547,50\end{array}$ & $\begin{array}{l}\text { So ja } \\
734,58\end{array}$ & $\begin{array}{l}\text { Ervil } \\
0\end{array}$ & $\begin{array}{l}\text { Milho } \\
734,76\end{array}$ & \\
\hline & $\begin{array}{l}\text { Ervil } \\
\quad 0\end{array}$ & $\begin{array}{l}\text { Milho } \\
291,42\end{array}$ & $\begin{array}{l}\text { Ave ia } \\
350,61\end{array}$ & $\begin{array}{l}\text { So ja } \\
556,74\end{array}$ & \\
\hline & $\begin{array}{l}\text { Ave ia } \\
379,60\end{array}$ & $\begin{array}{l}\text { Soja } \\
724,68\end{array}$ & $\begin{array}{l}\text { Trigo } \\
624,15\end{array}$ & $\begin{array}{l}\text { Soja } \\
556,02\end{array}$ & $5.500,06$ \\
\hline $\begin{array}{l}\text { Rotação, com três } \\
\text { invernos sem trigo }\end{array}$ & $\begin{array}{l}\text { Cevada } \\
361,95\end{array}$ & $\begin{array}{l}\text { Soja } \\
723,78\end{array}$ & $\begin{array}{l}\text { Ave i a } \\
398,97\end{array}$ & $\begin{array}{l}\text { Soja } \\
522,00\end{array}$ & \\
\hline & $\begin{array}{l}\text { Ave ia } \\
374,14\end{array}$ & $\begin{array}{l}\text { So ja } \\
733,14\end{array}$ & $\begin{array}{l}\text { Trigo } \\
586,05\end{array}$ & $\begin{array}{l}\text { So ja } \\
545,58\end{array}$ & \\
\hline & $\begin{array}{l}\text { Trigo } \\
549,90\end{array}$ & $\begin{array}{l}\text { Soja } \\
716,94\end{array}$ & $\begin{array}{l}\text { Ervil } \\
\text { O }\end{array}$ & $\begin{array}{l}\text { Milho } \\
729,90\end{array}$ & \\
\hline & $\begin{array}{c}\text { Ervil } \\
0\end{array}$ & $\begin{array}{l}\text { Milho } \\
307,44\end{array}$ & $\begin{array}{l}\text { Cevada } \\
590,40\end{array}$ & $\begin{array}{l}\text { So ja } \\
597,96\end{array}$ & $7.738,15$ \\
\hline
\end{tabular}

Ervil.: ervilhaca 
Tabela 18. Efeitos de sistemas de rotação na receita bruta para trigo e soja, de 1990 e 1991, em plantio direto, em US\$ de maio de 1992 (US\$ 1: CR $\$ 2.849,25$ ).

Ano

Sistemas de rotação

$1.990 / 1991 \quad 1991 / 1.992$

invern॰ verã inverno verão Média

$\ldots \ldots \ldots$ US\$ $\$$ ha $\ldots \ldots \ldots$

Monocultura de trigo Trigo Soja Trigo Soja 472,80 b $719,28 \quad 572,10 \quad 547,38 \quad 577,89$

Rotação, com um Trigo Soja Trigo Soja inverno sem trigo 537,45 a $735,30 \quad 595,95 \quad 549,18 \quad 604,47$

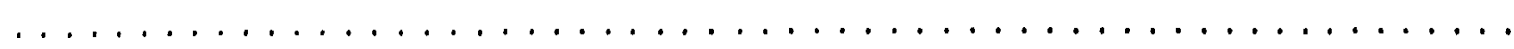

Rotação, com dois Trigo Soja Trigo Soja invernos sem trigo $547,50 a \quad 734,58 \quad 624,15 \quad 556,02 \quad 615,56$

$\begin{array}{clllll}\text { Rotação, com três } & \text { Trigo } & \text { Soja } & \text { Trigo } & \text { Soja } & \\ \text { invernos sem trigo } & 549,90 a & 716,94 & 586,05 & 545,58 & 599,61\end{array}$

$\begin{array}{lcrrrr}\text { Média } & 526,91 & 726,52 & 594,56 & 549,54 & 599,38 \\ \text { C.V. (\%) } & 5,42 & 3,30 & 6,86 & 4,77 & - \\ \text { F de tratamentos } & 6,51 * & 0,65 \mathrm{~ns} & 1,16 \mathrm{~ns} & 0,12 \mathrm{~ns} & 3,21 \mathrm{~ns}\end{array}$

Médias seguidas da mesma, letra na vertical, não apresentam diferenças significativas ao nível de $5 \%$ de probabilidade, pelo teste de Duncan.

*: nivel de significância de $5 \%$.

ns: não significativo. 
Tabela 19. Efeitos de sistemas de rotação na receita bruta para aveia, cevada e trigo, no inverno, e soja, no verão de 1990 e 1991, em plantio direto, em US\$ de maio de 1992 (US\$ 1: CR\$ $2.849,25$ ).

Ano

Sistemas de rotação

$1990 / 1991$

$1991 / 1992$

inverno verão inverno verão Média

$\ldots \ldots \ldots$ US\$ $\$ \ldots \ldots \ldots$

Monocultura de trigo Trigo Soja Trigo Soja

472,80 a $719,28 \quad 572,10 a \quad 547,38 \quad 577,89$

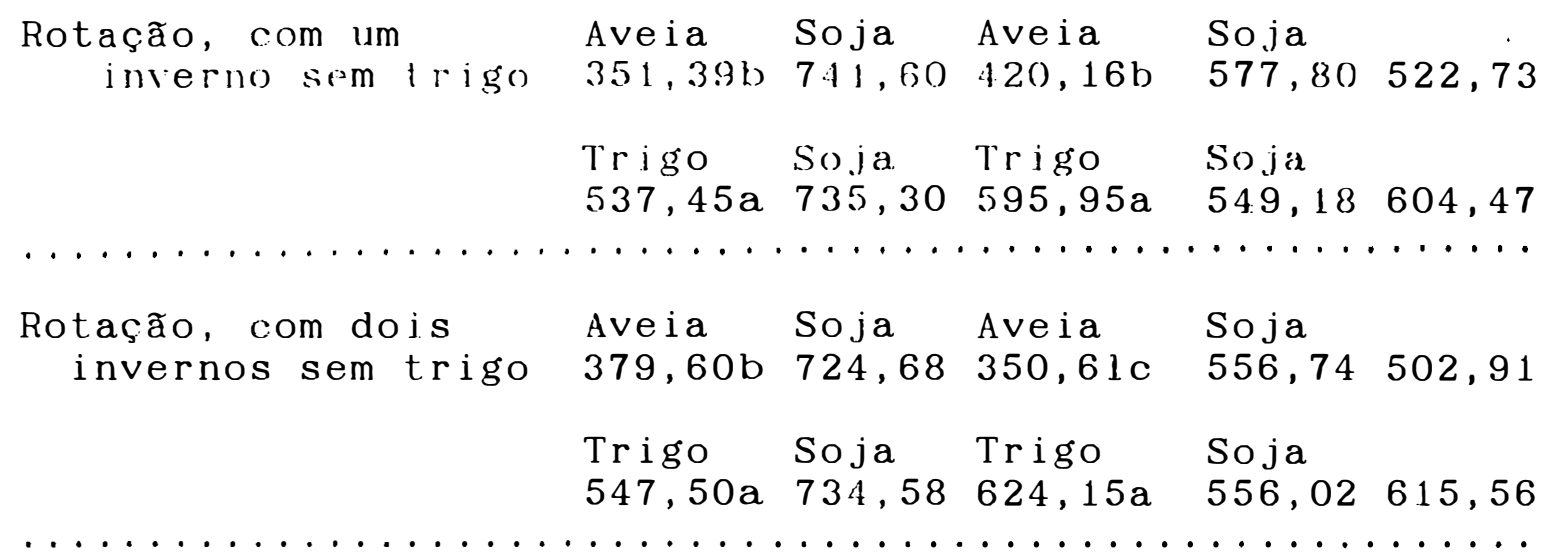

Rotação, com três Aveia Soja Aveia Soja

invernos sem trigo $374,14 \mathrm{~b} 733,14398,97$ bc 522,00 507,06

Cevada Soja Cevada Soja

$361,95 \mathrm{~b} \quad 723,78 \quad 590,40 \mathrm{a} \quad 597,96 \quad 568,52$

Trigo Soja Trigo Soja

549,90 a $716,94586,05 a \quad 545,58 \quad 599,61$

$\begin{array}{lrrrrr}\text { Média } & 446,84 & 728,66 & 517,29 & 556,58 & 562,34 \\ \text { C.V. (\%) } & 12,48 & 3,90 & 7,87 & 5,40 & - \\ \text { F de tratamentos } & 10,24 * * & 0,37 \mathrm{~ns} & 28,25 * * & 2,29 \mathrm{~ns} & 2,06 \mathrm{~ns}\end{array}$

Médias seguidas da mesma, letra na vertical, não apresentam diferenças significativas ao nível de 5\% de probabilidade, pelo teste de Duncan.

**: nivel de significância de $1 \%$.

ns: não significativo. 
Tabela 20. Receita líquida dos sistemas de rotação para trigo com culturas de inverno e de verão, de 1990 e 1991, em plantio direto, em US\$ de maio de 1992 (US\$ 1: CR\$ 2.849,25).

\begin{tabular}{|c|c|c|c|c|c|}
\hline \multirow{2}{*}{$\begin{array}{l}\text { Sistemas de } \\
\text { rotação }\end{array}$} & \multicolumn{4}{|c|}{ Ano } & \multirow[b]{2}{*}{ Total } \\
\hline & \multicolumn{2}{|c|}{$1990 / 1991$} & \multicolumn{2}{|c|}{$1991 / 1992$} & \\
\hline & $\ldots \ldots$ & $\cdots \cdots$ & - US\$/ha & $\cdots \ldots$ & $\cdots$ \\
\hline $\begin{array}{r}\text { Monocultura de } \\
\text { trigo }\end{array}$ & $\begin{array}{l}\text { Trigo } \\
+156,52\end{array}$ & $\begin{array}{l}\text { Soja } \\
+464,04\end{array}$ & $\begin{array}{l}\text { Trigo } \\
+319,05\end{array}$ & $\begin{array}{l}\text { So ja } \\
+335,55\end{array}$ & $+1.275,16$ \\
\hline$\ldots \ldots \ldots$ & $\ldots \ldots$ & $\cdots \cdots \cdots$ & $\cdots \cdots \cdots$ & $\ldots \ldots$ & $\ldots \ldots \ldots$ \\
\hline $\begin{array}{l}\text { Rotacão, com } \\
\text { um inverno }\end{array}$ & $\begin{array}{l}\text { Trigo } \\
+221,17\end{array}$ & $\begin{array}{l}\text { So ja } \\
+480,06\end{array}$ & $\begin{array}{l}\text { Ave ia } \\
+186,24\end{array}$ & $\begin{array}{l}\text { So ja } \\
+365,97\end{array}$ & \\
\hline & $\begin{array}{l}\text { Ave i a } \\
\quad+32,52\end{array}$ & $\begin{array}{l}\text { So ja } \\
+486,36\end{array}$ & $\begin{array}{l}\text { Trigo } \\
+342,90\end{array}$ & $\begin{array}{l}\text { Soja } \\
+337,35\end{array}$ & $+2.452,57$ \\
\hline 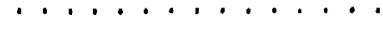 & $\cdots \cdots$ & $\cdots \cdots \cdots \cdot$ & $\cdots \cdots \cdots$ & $\cdots \cdots \cdots$ & $\cdots \ldots \ldots$ \\
\hline $\begin{array}{l}\text { Rotação, com } \\
\text { dois invernos }\end{array}$ & $\begin{array}{l}\text { Trigo } \\
+231,22\end{array}$ & $\begin{array}{l}\text { So ja } \\
+479,34\end{array}$ & $\begin{array}{c}\text { Ervil } \\
0\end{array}$ & $\begin{array}{l}\text { Milho } \\
+412,43\end{array}$ & \\
\hline & $\begin{array}{c}\text { Ervil } \\
0\end{array}$ & $\begin{array}{l}\text { Milho } \\
\quad-35,02\end{array}$ & $\begin{array}{l}\text { Ave i a } \\
+116,69\end{array}$ & $\begin{array}{l}\text { So ja } \\
+344,91\end{array}$ & \\
\hline & $\begin{array}{l}\text { Aveia } \\
\quad+60,73\end{array}$ & $\begin{array}{l}\text { So.ja } \\
+469,44\end{array}$ & $\begin{array}{l}\text { Trigo } \\
+371,10\end{array}$ & $\begin{array}{l}\text { So ja } \\
+344,19\end{array}$ & $+2.795,03$ \\
\hline 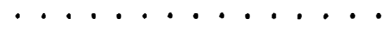 & 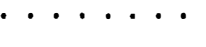 & $\cdots \cdots \cdots$ & $\cdots \cdots \cdots$ & $\cdots \cdots \cdots$ & $\cdots \cdots \cdots$ \\
\hline $\begin{array}{l}\text { Rotação, com } \\
\text { três invernos }\end{array}$ & $\begin{array}{l}\text { Cevada } \\
\quad+4,27\end{array}$ & $\begin{array}{l}\text { So ja } \\
+468,54\end{array}$ & $\begin{array}{l}\text { Ave i a } \\
+165,05\end{array}$ & $\begin{array}{l}\text { Soja } \\
+310,17\end{array}$ & \\
\hline & $\begin{array}{l}\text { Ave i a } \\
\quad+55,27\end{array}$ & $\begin{array}{l}\text { So ja } \\
+477,90\end{array}$ & $\begin{array}{l}\text { Trigo } \\
+333,00\end{array}$ & $\begin{array}{l}\text { So ja } \\
+333,75\end{array}$ & \\
\hline & $\begin{array}{l}\text { Trigo } \\
+233,62\end{array}$ & $\begin{array}{l}\text { Soja } \\
+461,70\end{array}$ & $\begin{array}{c}\text { Ervil } \\
0\end{array}$ & $\begin{array}{l}\text { Milho } \\
+407,57\end{array}$ & \\
\hline & $\begin{array}{c}\text { Ervil } \\
0\end{array}$ & $\begin{array}{l}\text { Milho } \\
\quad-19,00\end{array}$ & $\begin{array}{l}\text { Cevada } \\
+342,18\end{array}$ & $\begin{array}{l}\text { Soja } \\
+386,13\end{array}$ & $+3.960,15$ \\
\hline
\end{tabular}

Ervil.: ervilhaca 
Tabela 21. Efeitos de sistemas de rotação na receita 11quida para trigo e soja, de 1990 e 1991, em plantio direto, em US\$ de maio de 1992 (US\$ 1: CR\$ 2.849,25).

\begin{tabular}{|c|c|c|c|c|c|}
\hline \multirow{2}{*}{ Sistemas de rotação } & \multicolumn{4}{|c|}{ Ano } & \multirow[b]{2}{*}{ Média } \\
\hline & \multicolumn{2}{|c|}{$1990 / 1391$} & \multicolumn{2}{|c|}{ 1.991/1992 } & \\
\hline & $\ldots \ldots$ & $\ldots \ldots \mathrm{I}$ & US\$/ha & & \\
\hline Monocultura de trigo & $\begin{array}{l}\text { Trigo } \\
156,52 b\end{array}$ & $\begin{array}{l}\text { So ja } \\
464,04\end{array}$ & $\begin{array}{l}\text { Trigo } \\
319,05\end{array}$ & $\begin{array}{l}\text { So ja } \\
335,55\end{array}$ & 318,79 \\
\hline $\begin{array}{l}\text { Rotação, com um } \\
\text { inverno sem trigo }\end{array}$ & $\begin{array}{l}\text { Trigo } \\
221,17 \mathrm{a}\end{array}$ & $\begin{array}{l}\text { So ja } \\
480,06\end{array}$ & $\begin{array}{l}\text { Trigo } \\
342,90\end{array}$ & $\begin{array}{l}\text { So ja } \\
337,35\end{array}$ & 345,37 \\
\hline$\ldots \ldots \ldots \ldots$ & $\ldots \ldots$ & $\cdots \cdots$ & $\cdots \cdots \cdots$ & $\cdots \cdots \cdots$ & $\cdots \cdots$ \\
\hline $\begin{array}{l}\text { Rotação, com dois } \\
\text { invernos sem trigo }\end{array}$ & $\begin{array}{l}\operatorname{Tr} \text { igo } \\
231,22 \mathrm{a}\end{array}$ & $\begin{array}{l}\text { So ja } \\
479,34\end{array}$ & $\begin{array}{l}\text { Trigo } \\
371,10\end{array}$ & $\begin{array}{l}\text { So ja } \\
344,19\end{array}$ & 356,46 \\
\hline$\cdots \cdots \cdots \cdots \cdots \cdots$ & - & $\cdots \cdots \cdot$ & $\cdots \cdots \cdots$ & $\cdots \cdots \cdots$ & $\cdots \cdots \cdot$ \\
\hline $\begin{array}{l}\text { Rotação, com três } \\
\text { invernos sem trigo }\end{array}$ & $\begin{array}{l}\text { Trigo } \\
233,62 \mathrm{a}\end{array}$ & $\begin{array}{l}\text { So ja } \\
461,70\end{array}$ & $\begin{array}{l}\text { Trigo } \\
333,00\end{array}$ & $\begin{array}{l}\text { So ja } \\
333,75\end{array}$ & 340,51 \\
\hline $\begin{array}{l}\text { Média } \\
\text { C.V. (\%) } \\
\text { F de tratamentos }\end{array}$ & $\begin{array}{r}210,63 \\
13,56 \\
6,51 *\end{array}$ & $\begin{array}{r}471,28 \\
5,09 \\
0,65 \mathrm{~ns}\end{array}$ & $\begin{array}{l}341,51 \\
11,94 \\
1,16 \mathrm{~ns}\end{array}$ & $\begin{array}{r}337,71 \\
7,75 \\
0,12 \mathrm{~ns}\end{array}$ & 340,28 \\
\hline
\end{tabular}

Médias seguidas da mesma, letra na vertical, não apresentam diferenças significativas ao nivel de $5 \%$ de probabilidade, pelo teste de Duncan.

*: nivel de significância de $5 \%$.

ns: não significativo. 
Tabela 22. Efeitos de sistemas de rotação na receita liquida para aveia, cevada e trigo, no inverno, e soja, no verão de 1990 e 1991, em plantio direto, em US\$ de maio de 1992 (US\$ 1: CRS $2.849,25$ ).

\section{Ano}

Sistemas de rotação

$1990 / 1991$

$1991 / 1992$

inverno verão inverno verão Média

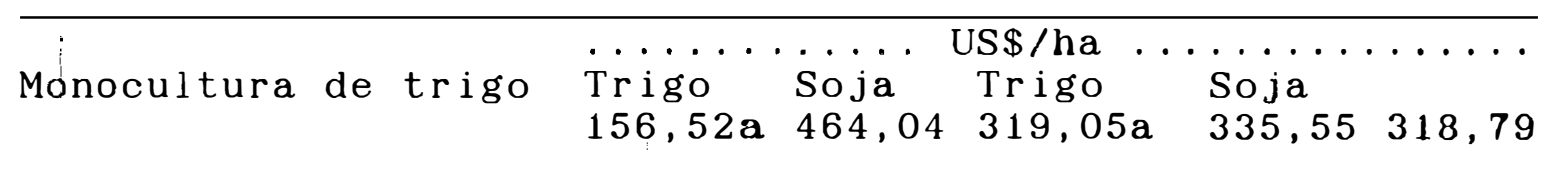

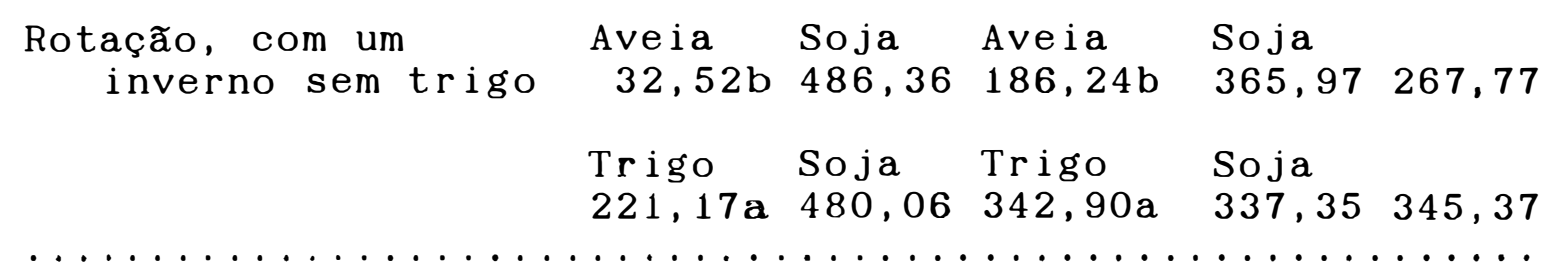

Rotação, com dois Aveia Soja Aveia Soja

invernos sem trigo $60,73 b \quad 469,44 \quad 116,69 c \quad 344,91247,94$

Trigo Soja Trigo Soja

231,22 a $479,34 \quad 371,10 a \quad 344,19356,46$

Rotação, com três Aveia Soja Aveia Soja

invernos sem trigo $55,27 \mathrm{~b} \quad 477,90 \quad 165,05 \mathrm{bc} \quad 310,17252,09$

$\begin{array}{cllll}\text { Cevada } & \text { Soja } & \text { Cevada } & \text { Soja } & \\ 4,27 b & 468,54 & 342,18 a & 386,13 & 300,28\end{array}$

Trigo Soja Trigo Soja

$233,62 \mathfrak{a} \quad 461,70 \quad 333,00 a \quad 333,75 \quad 340,51$

\begin{tabular}{l|rrrrr} 
Média & 124,41 & 473,42 & 272,03 & 344,75 & 303,65 \\
C.V. (\%) & 44,84 & 7,16 & 14,96 & 8,71 & - \\
F de tratamentos & $12,02 * *$ & $0,50 \mathrm{~ns}$ & $23,68 *$ & $2,29 \mathrm{~ns}$ & $1,82 \mathrm{~ns}$
\end{tabular}

Médias seguidas da mesma, letra na vertical, não apresentam diferenças significativas ao nivel de $5 \%$ de probabilidade. pelo teste de Duncan.

**: nível de significância de $1 \%$.

ns: não significativo. 
4.4. Evolução da fertilidade do solo

Os resultados referentes à avaliação dos efeitos dos diversos sistemas de rotação, sobre pH, alumínio trocável, cálcio + magnésio trocáveis, matéria orgânica, fósforo extraível e potássio trocável, na camada arável e em quatro (4) profundidades do solo $(0-5 \mathrm{~cm}, 5-10 \mathrm{~cm}, 10-15 \mathrm{~cm}$ e 15-20 cm), em plantio direto, determinados após as culturas de inverno de 1991 e: depois de 29 meses após aplicação do calcário, podem ser observados nas Tabelas 23 a 26 .

Nas Figuras de 1 a 6 , é apresentada a distribuição média de algumas propriedades químicas do solo, nas quatro profundidades, obtidas a partir dos dados das Tabelas 23 a 26. Estes resultados representam os efeitos dos quatro sistemas de rotação para trigo, conduzidos sob plantio direto. 
Tabela 23. Valores médios de pH em água, Al trocável, $\mathrm{Ca}+M g$ trocáveis, maléria orgânica (M.O.), P extraivel e $K$ trocável na camada de solo de 0-5 $\mathrm{cm}$, determinada após as culturas de inverno no ano de 1991, em plantio direto.

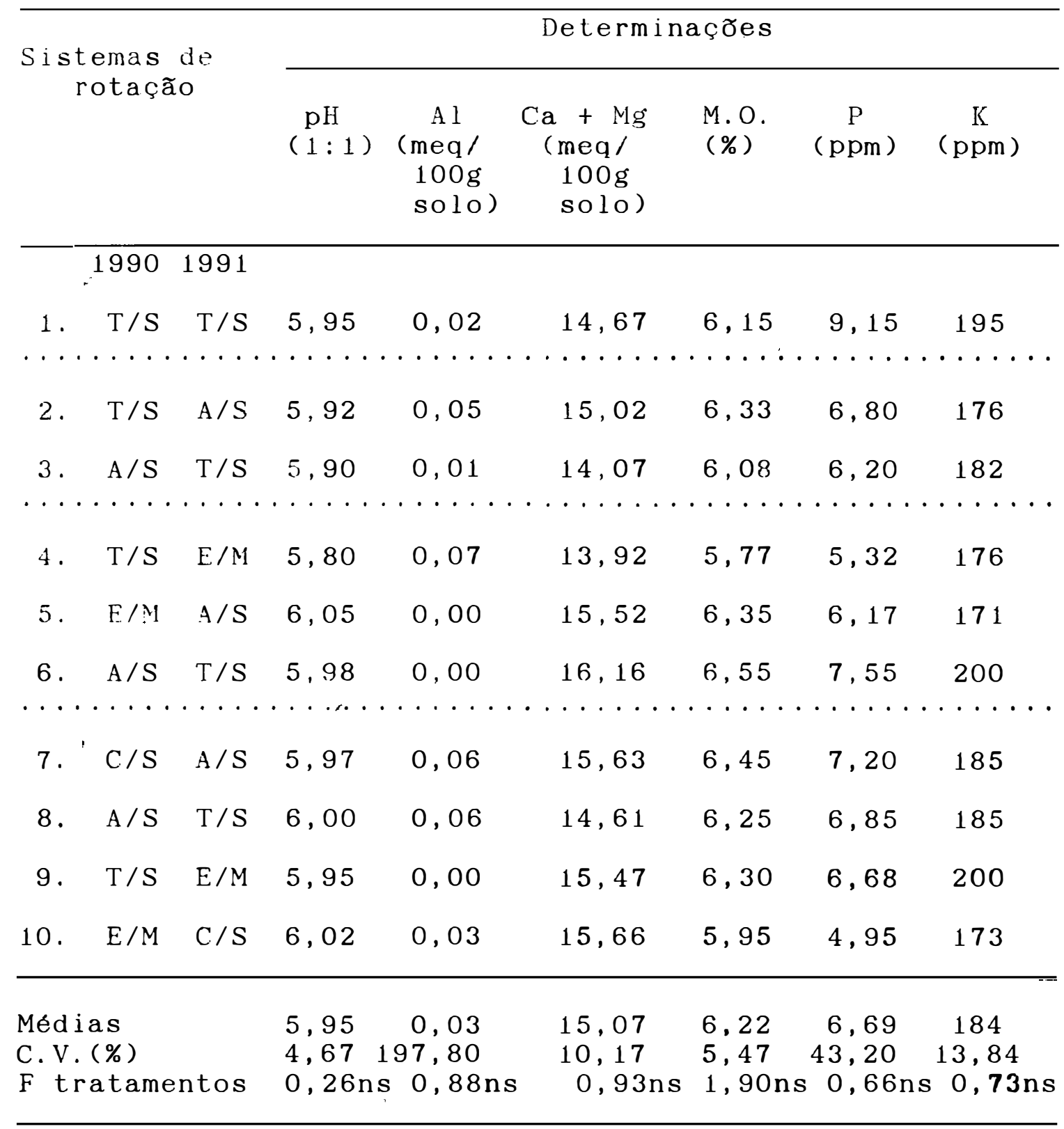

A: aveia, C: cevada, E: ervilhaca, $M$ : milho, $S:$ soja e T: trigo.

ns: não significativo. 
Tabela 24. Valores médios de $\mathrm{pH}$ em água, Al trocável, $\mathrm{Ca}+\mathrm{Mg}$ trocáveis, matéria orgânica (M.O.), P extraível e $K$ trocável na camada de solo de 5$10 \mathrm{~cm}$, determinada após as culturas de inverno no ano de 1991 , em plantio direto.

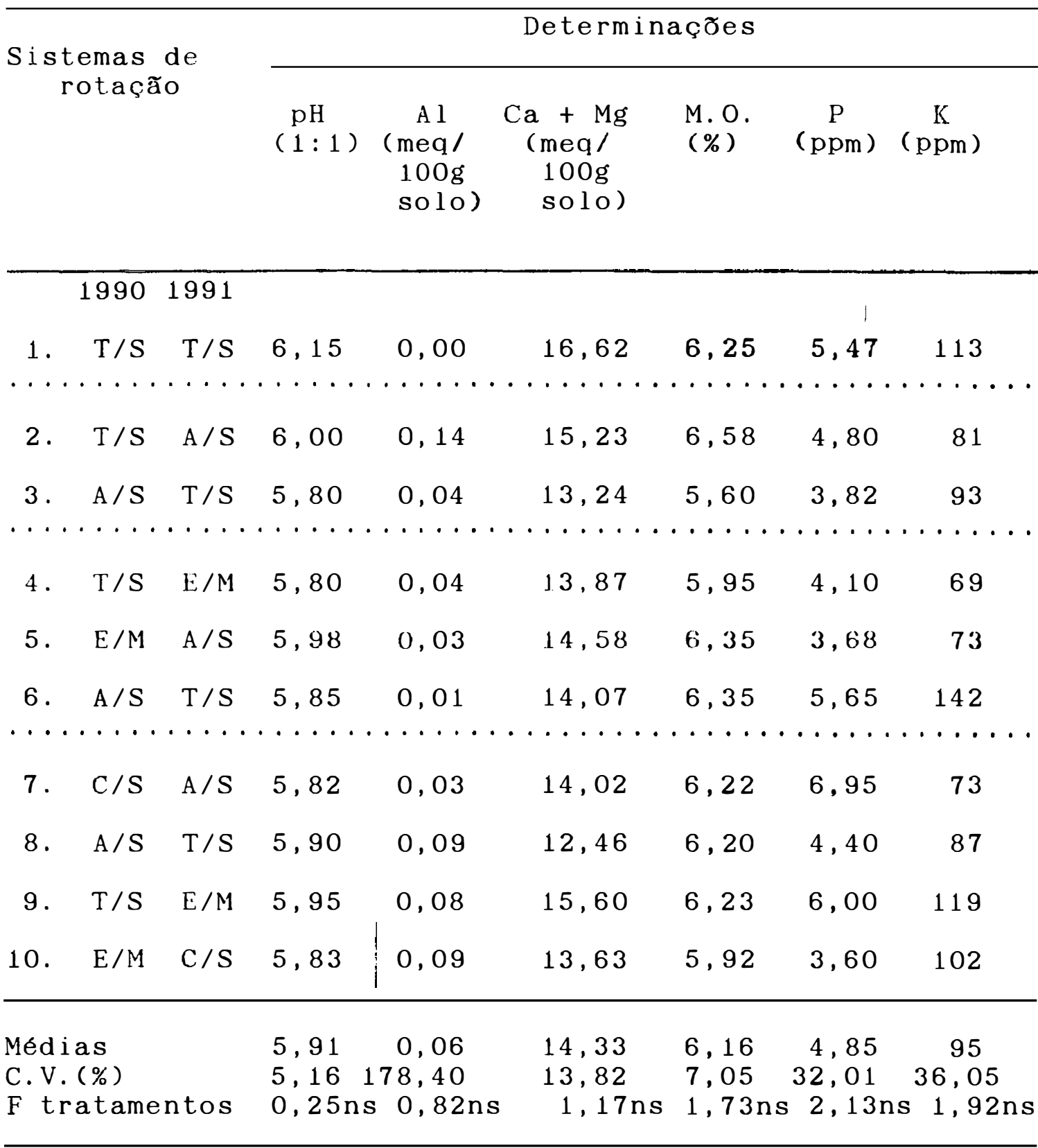

A: aveia, C: cevada, E: ervilhaca, M: milho, S: soja e T: trigo.

ns: não significativo. 
Tabela 25. Valores médios de $\mathrm{pH}$ em água, Al trocável, $\mathrm{Ca}+\mathrm{Mg}$ trocáveis, matéria orgânica (M.O.), $\mathrm{P}$ extraível e K trocável na camada de solo de 10$15 \mathrm{~cm}$, determinada após as culturas de inverno no ano de 1991, em plantio direto.

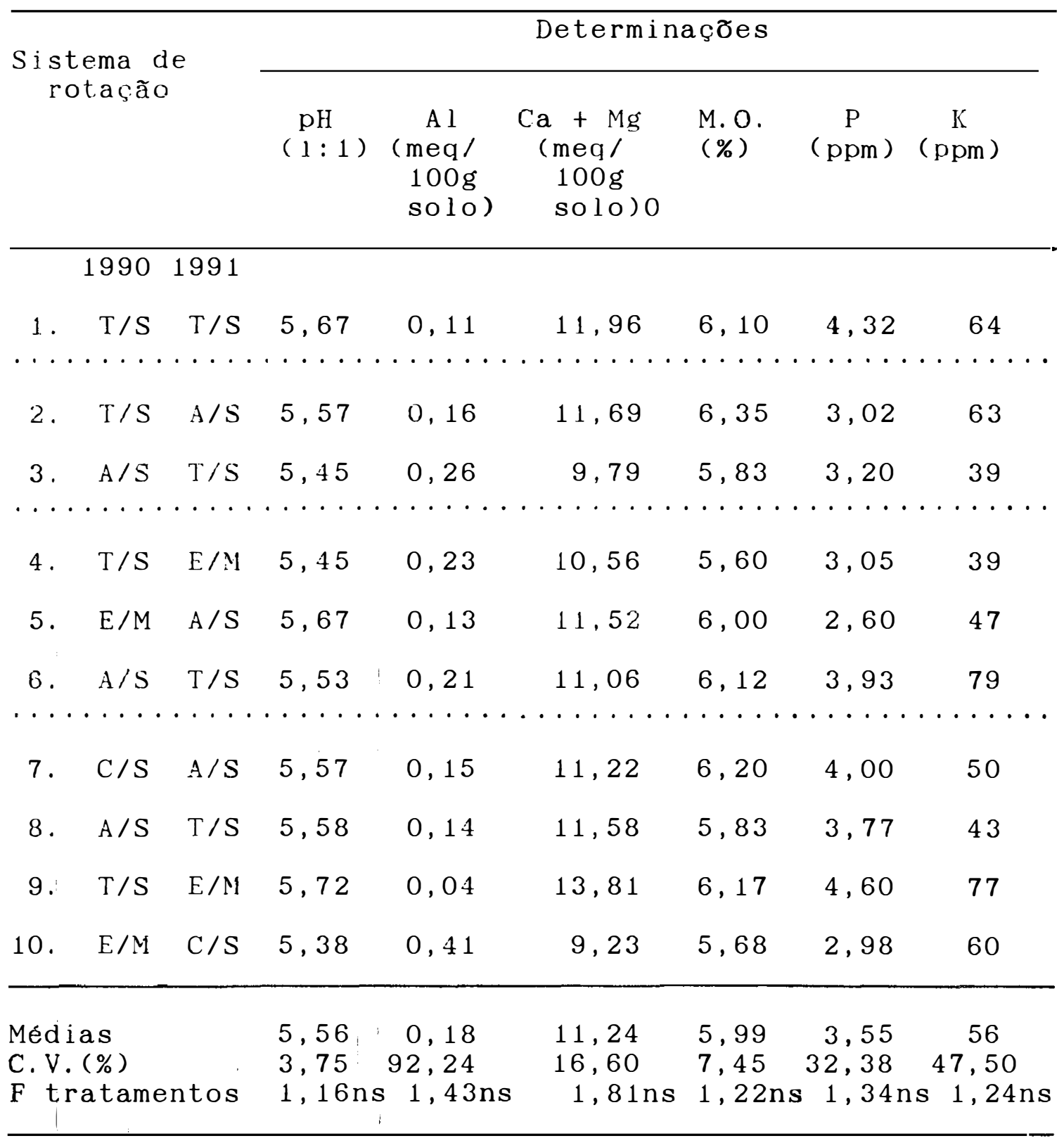

A: aveia, C: cevada, E: ervilhaca, M: milho, S: soja e T: trigo.

ns: não significativo. 
Tabela 26. Valores médios de pH em água, Al trocável, $\mathrm{Ca}+\mathrm{Mg}$ trocáveis, matéria orgânica (M.O.), P extraível e $K$ trocável na camada de solo de 15$20 \mathrm{~cm}$, determinada após as culturas de inverno no ano de 1991, em plantio direto.

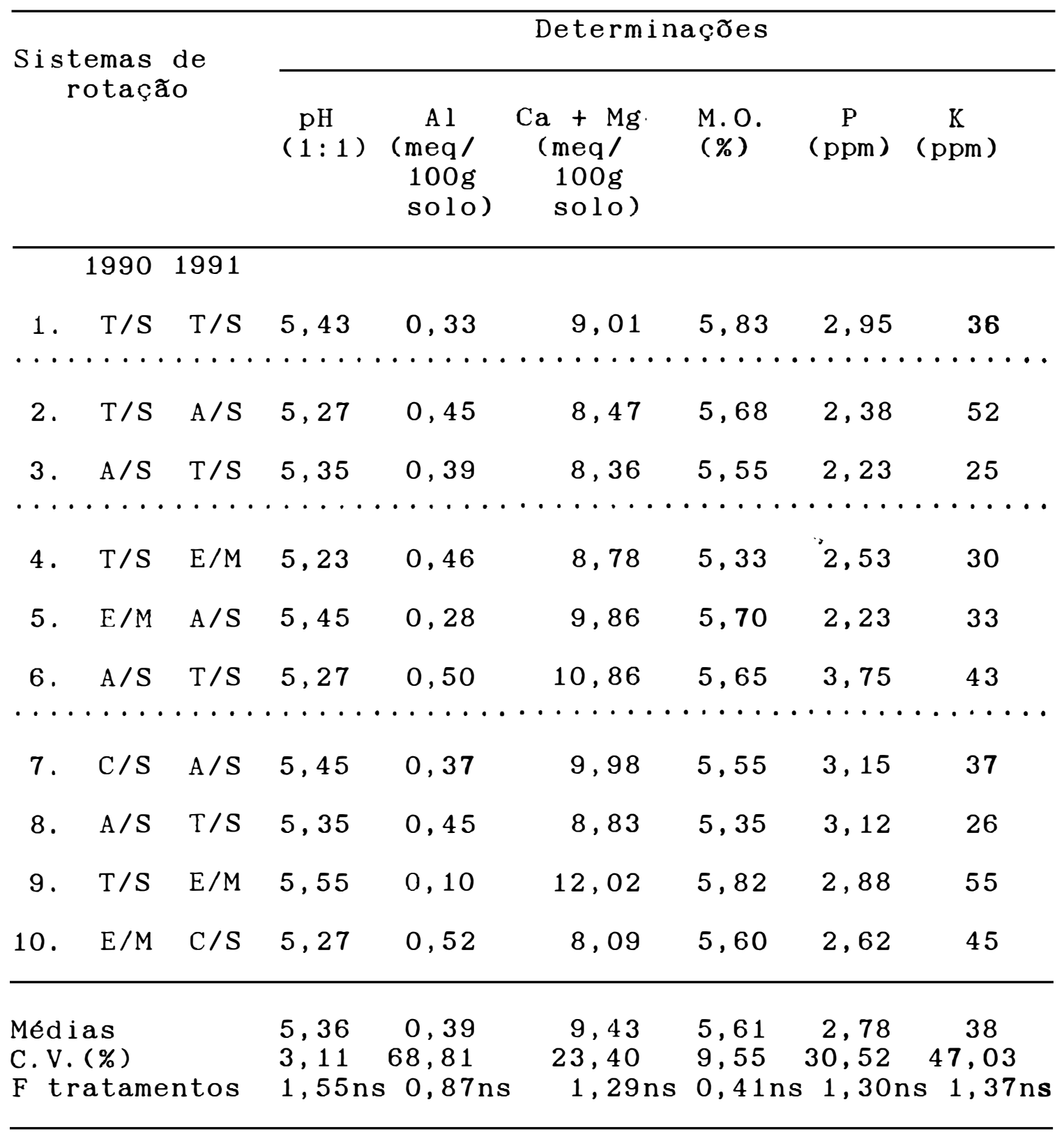

A: aveia, C: cevada, E: ervilhaca, M: milho, S: soja e T: trigo.

ns: não significativo. 
Figura 1. Valores médios de pH (em ágúa) em quatro profundidades, após as culturas de inverno no ano de 1991 , plantio direto.

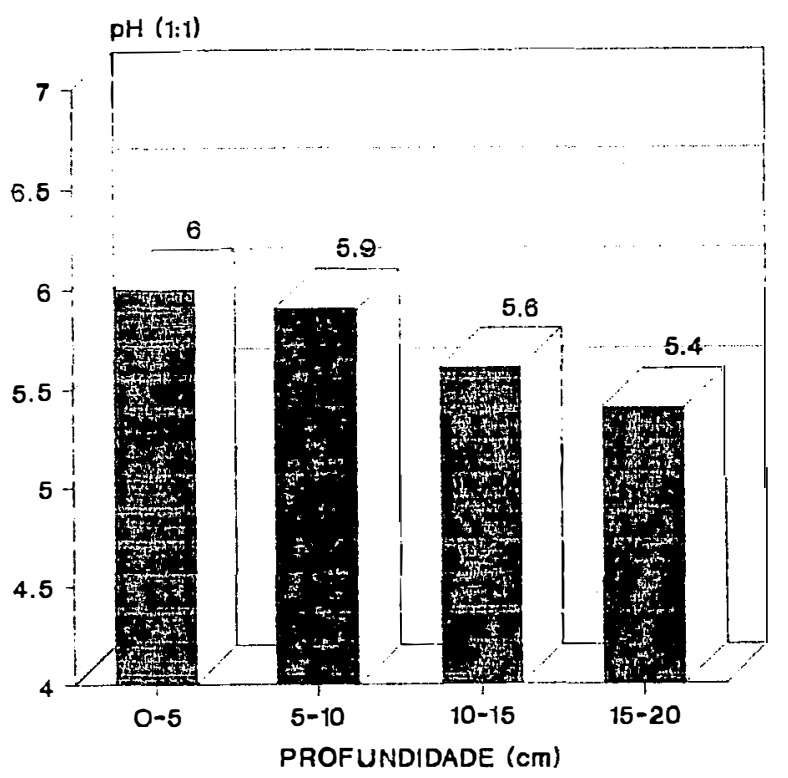

\section{MEDIAS}

Figura 2. Valores médios de Al em quatro profundidades, após as culturas de inverno no ano de 1991, em plantio direto.

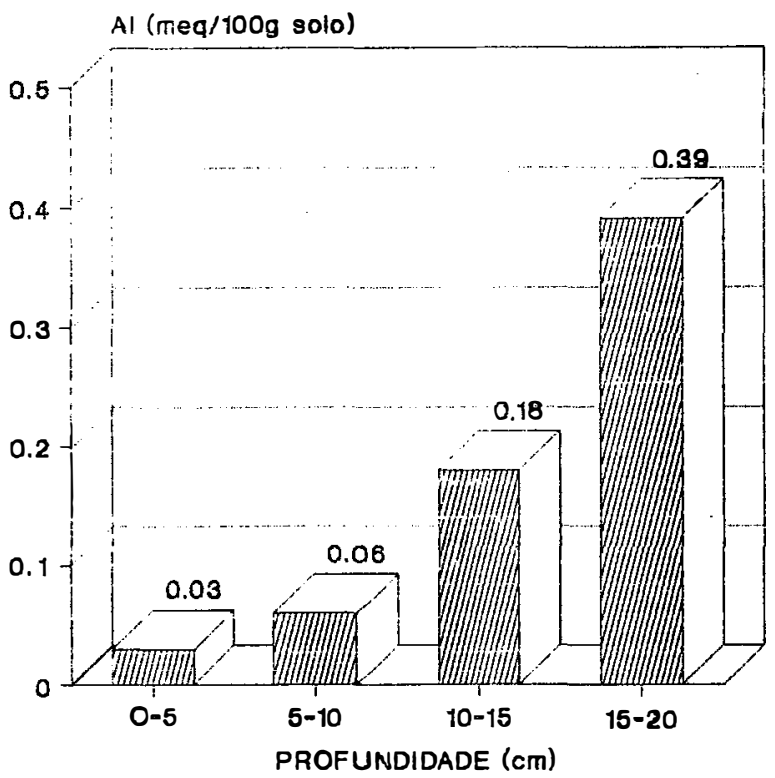

WIIIIII MEDIAS 
Figura 3. Valores de Ca + Mg trocáveis em quatro profundidades, após as culturas de inverno no ano de 1991, em plantio direto.

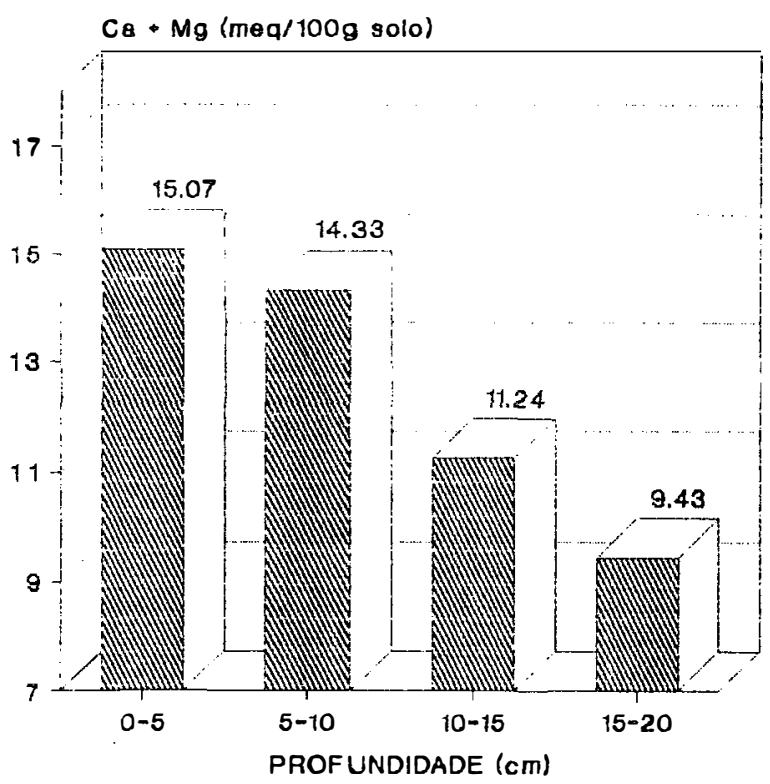

\section{IUSTIU MEDIAS}

Figura 4. Teores de matéria orgânica em quatro profundidades, após as culturas de inverno no ano de 1991, em plantio direto.

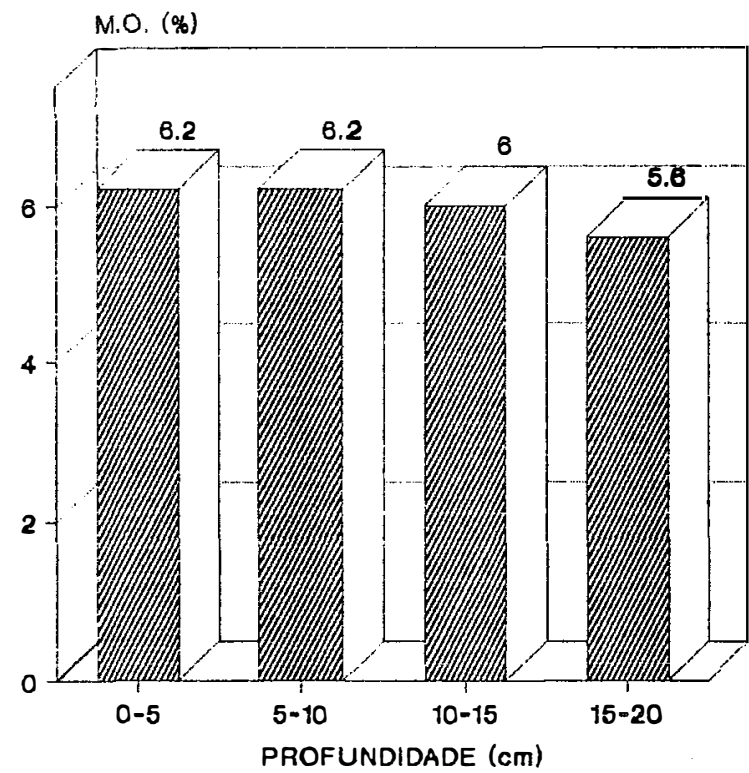

WIID MEDIAS 
Figura 5. Valores de P extraível em quatro profundidades, após as culturas de inverno no ano de 1991, em plantio direto.
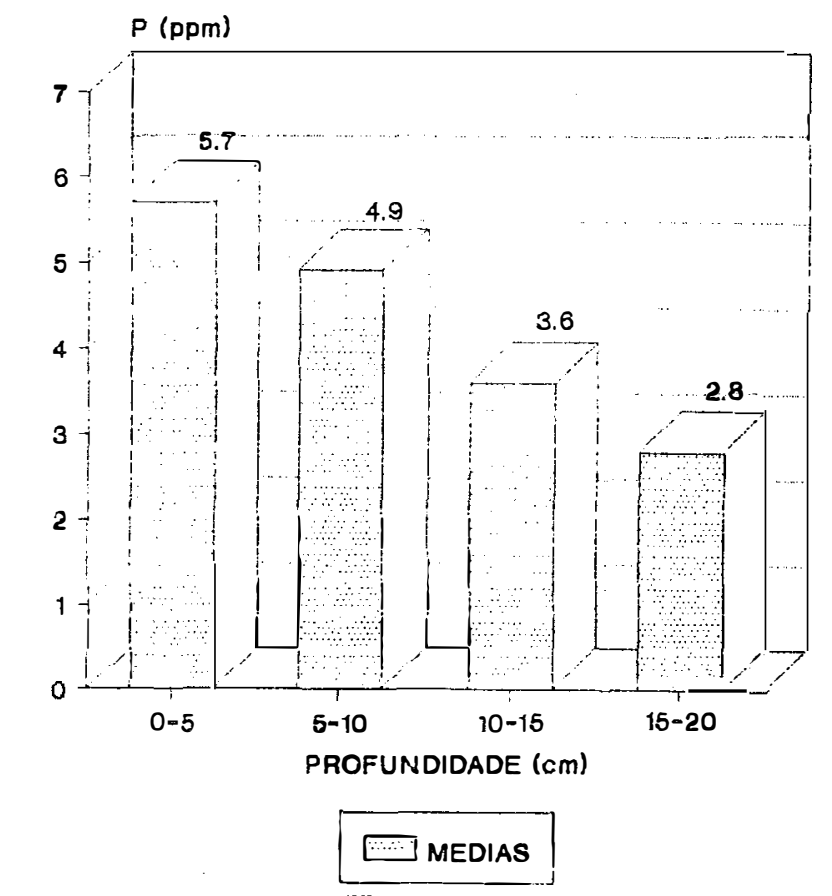

Figura 6. Valores de $K$ trocável em quatro profundidades, após as culturas de inverno no ano de 1991, em plantio direto.

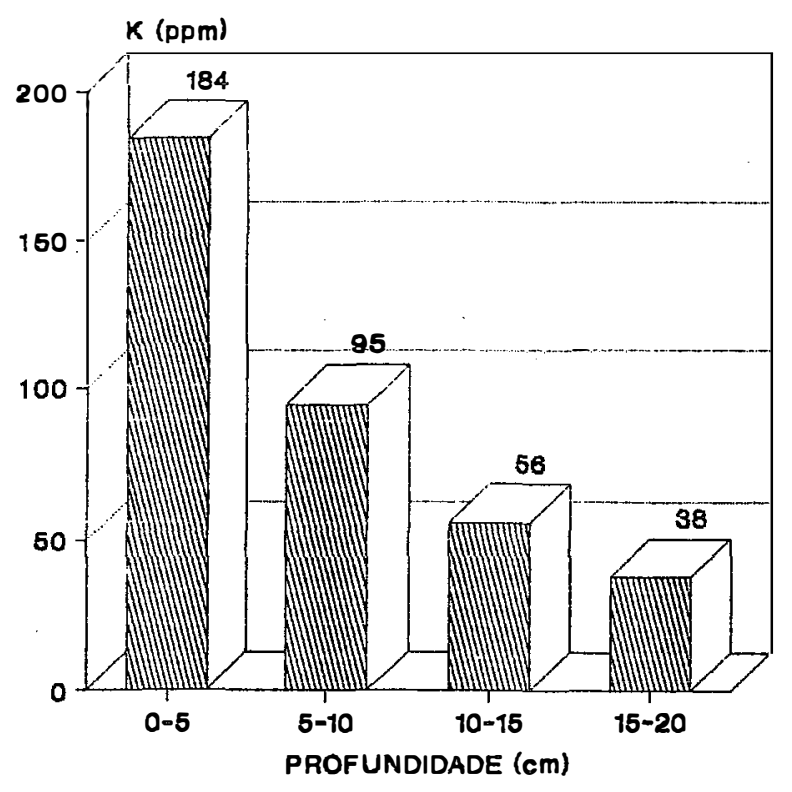

血耑霜 MEDIAS 


\section{DISCUSSÃO}

Os resultados a serem discutidos foram gerados no período agrícola de 1990 a 1991, em experimento instalado desde 1984, em área da Cooperativa Agrária Mista Entre Rios Ltda., em Guarapuava, PR, com sistemas de rotação para trigo, incluíndo culturas de inverno e de verão em plantio direto. Para melhor compreensão do assunto tratado, șerão utilizados na discussão, os mesmos itens mencionados no capitulo anterior.

5.1. Rendimentos de grãos de milho, de soja e de trigo e intensidade de doenças do sistema radicular de trigo.

Para a cultura de milho não houve diferença entre os tratamentos, em relação ao sistema de rotação de culturas e o rendimento de grãos, na análise individual e conjunta dos dados (Tabela 8). Tais resultados foram semelhantes aos obtidos por SANTOS et al. (1987c) e SANTOS \& PÖTTKER (1990), quando compararam o rendimento de grãos de milho após ervilhaca e serradela, em sistemas de rotação de culturas e por SANTOS et al. (1987e) estudando milho após ervilhaca e tremoço. 
Pelos resultados obtidos, não foram constatadas diferenças significativas entre o rendimento de grãos de milho cultivado por dois ou três verơes, intercalado pela cultura de soja (Tabela 8). Isto pode ser explicado, pelo fato de não ter ocorrido efeito significativo para os componentes de rendimento do milho, na interação ano $x$ tipo de sucessão.

No período agrícola de 1990/1991, milho apresentou rendimento de grãos da ordem de $144 \%$ abaixo daquele obtido em 1991/1992, devido a precipitação pluvial ter sido abaixo da média, característica da região, durante quase todo o ciclo, prejudicando o crescimento e o desenvolvimento das plantas (Tabela 1). Além disso, foram roubadas várias espigas, quando as plantas de milho encontravam-se no estádio de grão leitoso, o que dificultou em parte, a avaliação final.

No período agrícola de 1991/1992, em ano considerado normal, o rendimento de grãos de milho, esteve próximo aos obtidos por SANTOS et al. (1989b), no mesmo experimento. Cumpre ressaltar que, neste mesmo ano houve uma melhor distribuição de chuvas durante o ciclo dessa gramínea. No caso da cultura de soja, não houve igualmente diferenças entre os tratamentos, em relação aos sistemas de rotação de culturas e o rendimento de grãos, na análise individual e na análise conjunta dos resultados, conforme constatado na Tabela 9 . Os dados indicaram que, a 
soja após a aveia branca, a cevada e o trigo, pode ser incluida, sem prejuízos, nos diferentes sistemas de rotação, recomendado para a Região Sul do Brasil (REUNIÃO DE PESQUISA DE SOJA PARA A REGIT̃O SUL, 1989). Tal fato vem comprovar os resultados já obtidos por SANTOS \& PEREIRA (1987), SANTOS et al. (1989b e 1991b) e SANTOS \& RELS (1990).

No período avaliado, não foram verificadas diferenças significativas entre o rendimento de grãos de soja cultivada em monocultura ou por dois ou três verões, alternado por milho (Tabela 9). Isto está relacionado ao fato de não ter havido efeito significativo para os componentes de rendimento, na interação ano $x$ tipos de sucessão.

Observou-se que, os resíduos de cevada e de trigo possibilitaram cobertura adequada do solo, enquanto que os de aveia branca, para grãos, ofereceram quantidades relativamente acentuadas. Observações semelhantes foram relatadas por SANTOS (1991) e SANTOS et al. (1991b e 1991c). Por outro lado, a cultura de aveia branca e de ervilhaca, que possuem um ciclo mais longo do que a cevada e o trigo, foram estabelecidas nas suas melhores épocas de semeadura, devido ao não preparo da área (plantio direto). Isto por sua vez, facilitou que a soja fosse semeada numa única data, o que permitiu a continuidade dos sistemas de produção. Portanto, o plantio direto permitiu, também, que o milho e a soja fossem semeados dentro de suas melhores épocas.

Com relação às doenças do sistema radicular do 
trigo, nos anos de 1990 e 1991, a intensidade das podridðes radiculares desse cereal (Gaeumannomyces graminis var. tritici e Bipolaris sorokiniana), apresentou diferenças significativas entre os tratamentos, conforme observado na Tabela 10. Pela análise dos dados, evidenciou-se que os valores mais elevados ocorreram, de um modo geral, na monocultura de trigo, em relação aos demais tratamentos. Isto, por sua vez, não foi significativo para mostrar diferenças entre os tratamentos, na análise conjunta dos dados. Estes resultados foram semelhantes aos encontrados por SANTOS et al. (1991a), para a cultura de cevada. Ressalta-se que, o fato de não ter havido diferenças entre os tratamentos para a intensidade das doenças do sistema radicular de trigo, foi devido a falta de consistência dos dados, do ano de 1991, onde o referido problema foi também constatado no tratamento correspondente à rotação de culturas àpresentando um inverno sem trigo.

Para o rendimento de grãos de trigo, houveram diferenças significativas entre os tratamentos no ano de 1990 (Tabela 11). O menor rendimento de grãos manifestou-se na monocultura de trigo, em comparação com os demais tratamentos sob rotação. No ano seguinte, e na análise conjunta dos dados, não foram observadas diferenças entre os tratamentos. Da mesma forma, SANTOS et al. (1991a) obtiveram resultado semelhante para a cultura de cevada.

Como trata-se de ensaio de rotação de culturas 
para trigo, em plantio direto, seria de se esperar diferenças mais relevantes entre os quatro sistemas de rotação, para a intensidade das doenças do sistema radicular e para o rendimento de grãos. No entanto, isto não foi observado, possivelmente. derido à ocorrência de condiçơs desfavoráveis ao desenvolvimento das doenças do sistema sistema radicular, as quais se manifestaram em menor intensidade e nas fases menos critica de trigo, conforme já verificado e mencionado por SANTOS et al. (1991a).

Deve ser levado em consideração que, os efeitos da rotaşa de culturas ficam melhor demonstrados em anos desfavoraveis, ou seja, excesso de precipitação pluvial e temperaturas relativamente elevadas, em relação à normal, durante quase todo o ciclo da cultura (REIS et al., 1983; SANTOS et al., 1987a e 1987d). Ist.o faz com que a intensidade das doenças do sistema radicular de trigo se manifeste em valores altos e nas fases mais criticas desse cereal, sem rotaçăo de inverno, consequentemente o rendimento de grãos diminui, chegando até ser nulo.

Em anos relativamente normais, sob o ponto de vista meteorológico (precipitação pluvial e temperatura próximo da média), como foram os anos de 1990 e 1991, a intensidade das doenças do sistema radicular, na monocultura, ocorreu com valores acima dos demais tratamentos, enquanto que, o rendimento de grãos, com valores abaixo, em relação às áreas com rotação de culturas. Resultados similares foram 
obtidos por SANTOS et al. 1990a. Neste caso, as doenças do sistema radicular de trigo, em monocultura, se manifestaram num limiar relativamente baixo e nas fases menos criticas da cultura.

O efeito do clima é fundamental para reduzir ou aumentar a intensidade das doenças do sistema radicular e da parte aérea de trigo, quando cultivado em monocultura (SANTOS et al. 1990a). Pelos dados obtidos, no presente trabalho, o efeito da rotação não foi marcante, em função do curto período de estudo considerado. Este fato, às vezes confunde o agricultor, tornando difícil a adoção desta tecnologia.

De forma geral, a rotação de culturas, mantém a estabilidade e o aumento do rendimento de grãos para a cultura de trigo, mesmo em anos meteorologicamente adversos.

5.2. Balanço energético dos sistemas de rotação para trigo

O balanço energético de cada espécie componente dos sistemas de rotação para trigo de 1990 a 1991 , foi ostimado com base na energia dispendida correspondente ao uso de insumos e na energia gasta nas operaroes de campo (semeadura, tratos culturais e semeadura), cujos indices são evidenciados nas Tabelas 2 a 6 do Apêndice, acrescido do rendimento de grãos das mesmas (Tabela 7). O balanço energético é função da produtividade cultural, que por sua 
vez foi obtida da razão entre o rendimento de cada espécie em estudo $e$ a energia cultural (insumos, semeadura, tratos culturais e colheita), conforme metodologia proposta por HEICHEL (1980), PIMENTEL (1980a), FILIPPE JUNIOR (1984) e MELLO (1986).

Em função disso, os valores obtidos e apresentados na Tabela 12, devem ser utilizados com certa cautela, pois tratam-se de coeficientes técnicos que, na sua quase totalidade foram calculados para paises estrangeiros, e adaptados no presente trabalho, às condiçơes da região de Guarapuava, PR. Além disso, nă foram computados o potencial genético das espécies envolvidas, bem como as condiçбes meteorológicas ocorrentes nesse período, que pudessell contribuir para a alteração desses indices.

Por outro lado, os dados obtidos possibilitaram a comparação entre os quatro sistemas de rotação para trigo (Tabela 13) e aqueles envolvendo as culturas de aveia, de cevada e de trigo, no inverno, e de soja, no verão, em plantio direto (Tabela 14).

0 balanço energético dos quatro sistemas de rotação para trigo, no inverno, e para soja, no verão, estão apresentados na Tabela 13. Pela análise desta tabela, verificou-se somente diferenças entre os tratamentos para a produtividade cultural no inverno de 1990. O trigo em monocultura apresentou menores indices energéticos de produtividade cultural $(1,935 \mathrm{~kg} / \mathrm{Mcal})$ do que este cereal em 
rotação por um $(2,200 \mathrm{~kg} / \mathrm{Mcal})$, dois $(2,240 \mathrm{~kg} / \mathrm{Mcal})$ e três invernos $(2,251 \mathrm{~kg} / \mathrm{Mcal})$. Isto indica que para cada unidade de Mcal investida nos sistemas com rotação de culturas para trigo, o rendimento foi inferior na monocultura deste cereal. Levando-se em consideração as espécies de inverno (aveia, cevada e trigo) e a soja, que compõem os sistemas de rotação para trigo, notou-se diferenças entre os tratamentos para produtividade cultural, nos invernos de 1990 e 1991 (Tabela 14). Observou-se que, a cultura de cevada, em 1990, apresentou menor Indice de produtividade cultural, correspondente a $1,422 \mathrm{~kg} / \mathrm{Mcal}$. Isto quer dizer que, em função do baixo desempenho, a cevada teve o menor aproveitamento energético do que os tratamentos com o trigo e com a aveia, no mesmo período agrícola. Em 1991, dois dos três tratamentos com aveia foram os que mostraram os menores indices de produtividade cultural, em comparação aos tratamentos com cevada e com trigo.

MELLO (1986), analisando sistemas de produção para várias espécies, no estado de Santa Catarina, obteve Indices energéticos para produtividade cultural, relativamente baixos para as culturas de milho e de soja, em preparo convencional, ou seja, 1,253 e 0,781 kg/Mcal, respectivamente.

Desta maneira, quando uma espécie não responde adequadamente aos seus investimentos energéticos, pode-se considerar que algum insumo está sendo desperdiçado e que 
poderia ser melhor aproveitado, principalmente, em paises onde existe carência de produtos agrícolas; como foi observado para a cevada, em 1990 e, para alguns tratamentos onde participou a aveia, em 1991. Isto também pode ser verdadeiro quando não forem utilizados sistemas racionais de manejo de cultura. Tal fato pode ser relacionado ao plantio de trigo em monocultura, em anos com excesso de precipitação pluvial ( $>1.000 \mathrm{~mm}$ ) e temperaturas relativamente elevadas ( $>18^{\circ} \mathrm{C}$ ), em relação à normal; onde o rendimento de grãos chega a ser nulo, devido a alta incidência de doenças, tanto do sistema radicular, como da parte aérea (REIS et al., 1983; SANTOS et al., 1987a e 1987d).

Por outro lado, espécies que apresentam rendimentos maiores pelo uso de insumos que demandam grandes quantidades de calorias, ocorrendo o dispêndio de mais energia do que nos sistemas com rendimentos menores e com menos consumo de energia (BERARDI 1978). Este caso pode ser interpretado de duas maneiras: o que é mais importante? Produzir mais, gastando grande quantidade de energia e suprir a possivel demanda de alimentos, fibras e resinas ou produzir menos, sem satisfazer essas necessidades? De um modo geral, quando se aumenta a produtividade de culturas, gasta-se mais energia. Todavia, deve-se almejar sistemas de rotação eficientes e racionais, fundamentados em uma atividade enegerticamente sustentável, buscando-se o máximo rendimento econômico . 
5.3. Análise econômica dos sistemas de rotação para trigo

Com base nos dados experimentais de 1990 e 1991, imputou-se valores monetários ás operaçơes e às produçōes obtidas afim de determinar seus custos e rentabilidades. A técnica utilizada foi de fluxo de caixa apoiado na teoria de custos num enfoque ex-post (realizada) segundo proposição de ANDIA et al. (1991).

Os resultados obtidos devem, porém, ser avaliados com cautela para evitar-se extrapolaçбes incorretas. Trata-se de observaçðes pontuais de monetarização das atividades e operações realizadas nas safras de 1990 e 1991, para os sistemas propostos, refletindas as condiçбes da época. Ademais, não capta detalhes com respeito ao potencial genético de cada espécie em estudo e nem as condiçס̃es meteorológicas, que podem ter afetadas o ciclo normal das culturas.

Desta maneira, as espécies de inverno tiveram os custos de insumos e de operaçðes de campo, mais elevados do que as espécies de verão, exceto a cultura de ervilhaca (Tabela 15). Por sua vez, a adubação de manutenção e a aplicação de herbicida, constituiram-se nos insumos que mais contribuiram para elevação dos custos das culturas em estudo (Tabela 1.6).

Considerando a receita bruta dos quatro sistemas de rotação para trigo, verificou-se diferenças entre 
os tratamentos somente no inverno de 1990 (Tabela 18). A monocultura do trigo apresentou menor receita bruta (US\$ $472,80)$, do que este cereal com um (US\$ 537,45$)$, dois (US\$ $547,50)$ e três invernos de rotaçăo de culturas (US\$ 549,90). Estes resultados refletem diretamente, o obtido para o rendimento de grãos.

Levando-se em conta a aveia, a cevada e o trigo, no inverno, e a soja, no verão, houve diferenças entre os tratamentos para a receita bruta, nos invernos de 1990 e 1991 (Tabela 19). Em 1990, os tratamentos com aveia e com cevada mostraram menores receitas brutas, respectivamente, US\$ 368,38 e 361,95, do que em comparaça aos tratamentos com trigo (US\$ 526,91). Em 1991, os tratamentos com aveia manifestaram menor receita bruta (US\$ 389,91 ), do que em relação aos demais tratamentos (cevada-US\$ 590,40 e trigo-US\$ $594,56)$.

No que tange à receita líquida dos quatro sistemas de rotação para trigo, foi evidenciado diferenças entre os tratamentos, igualmente no inverno de 1990 (Tabela 21). Da mesma forma, o trigo em monocultura apresentou menor receita liquida (US\$156,52), do que esta mesma gramínea em rotação por um (US\$221,17), dois (US\$231,22) e três invernos (US\$233,62). Assim, o menor retorno econômico foi 'obtido pelo trigo sob monocultura. Por outro lado, o melhor dẹsempenho econômico de trigo foi obtido sob rotação.

Neste caso, a mononocultura de trigo afetou 
negativamente a receita liquida, pois para todos os tratamentos com este cereal, foram utilizados os mesmos insumos e operações de campo.

Os resultados para a receita liquida, levandose em consideração as culturas de aveia, de cevada e de trigo, no inverno, e de soja, no verão, foram semelhantes aos óbtidos para a receita bruta, ou seja, houveram diferenças entre os tratamentos, nos invernos de 1990 e 1991. De um modo geral, o trigo apresentou maior receita liquida, que a aveia e a cevada. Neste caso, verificou-se que as culturas utilizadas como alternativas, apresentam normalmente baixo preço de venda e menor rendimento cultural o que contribui para o trigo ser, frequentemente, a espécie com melhor retorno econômico.

Resultados obtidos por ZENTNER et al. (1990), destacaram o sistema de rotação para cevada ou trigo, cultivado por um ano de rotação, como o que mostrou melhor receita liquida, em comparaçăo aos demais tratamentos.

Com base nos dados obtidos para rendimento de grãos, em 1990 (Tabela 11), aliado ao balanço energético (Tabela 13) e econômico (Tabela 21), o trigo cultivado em rotação de culturas, mostrou-se o sistema mais eficiente e racional de produção dessa gramínea para a região de Guarapuava, PR, em plantio direto. De qualquer forma, todas as culturas usadas neste estudo, já são recomendadas para aquela região; contudo, à niyel de agricultor não são 
observados esquemas fixos de rotação ou de manejo correto de solo. Desta forma, um sistema adequado de rotação de culturas pode permitir um melhor aproveitamento energético das calorias investidas e uma melhor rentabilidade da propriedade agrícola. Além disso, a rotação de culturas viabiliza o plantio direto, que por sua vez é o método mais eficiente de conservação de solo. De uma maneira geral, a integração destas práticas culturais irá refletir-se, positivamente, na maior riqueza do agricultor que é sua terra.

5.4. Evolução da fertilidade do solo

Estudo da evolução da fertilidade do solo nos sistemas de produção para trigo em plantio direto, foi realizada através de amostragem de solo, em quatro profundidades, no inverno de 1991.

Os níveis de nutrientes e de matéria orgânica do șolo, em quatro profundidades, após diversos cultivos, em plantio direto e depois de 29 meses após a aplicação de calcário, não apresentaram diferenças significativas entre os tratamentos, conforme consta nas Tabelas 23 a 26 . Neste período, não foi observado processo de acidificação de solo a partir da superfície (Figura 1), ratificando os resultados já obtidos por MUZILLI (1983). Ainda, pelos resultados verificados por SANTOS \& LHAMBY (1992) e SANTOS \& SIQUEIRA (1992), estes efeitos tornaram-se mais evidentes após cinco 
anos (dez cultivos, em plantio direto). Os valores de alumínio trocável foram menores na superficie (Figura 2), enguertc que fara os teores de cálcio t magnésio trocáveis ocorreu exatamente o contrárlo (Figura 3). Fara os valores de matéria orgânica do solo, houve uma acumulação progressiva, na superfície, ou seja, de 5,6 para $6,2 \%$, da profundidade de 15 a $20 \mathrm{~cm}$, para 0 a $5 \mathrm{~cm}$ (Figura 4). O fósforo extraível (Figura 5) e o potássio trocável (Figura 6), acumularam-se de forma similar, principalmente na camada de 0 a $5 \mathrm{~cm}$, correspondendo ao dobro ou o quáduplo da concentração registrada na camada de 15 a $20 \mathrm{~cm}$. Dados semelhantes foram obtidos por MUZILLI (1983), SANTOS \& LHAMBY (1992) e SANTOS \& SIQUEIRA $(1992)$ 
6. CONCLUSÕES

Os resultados obtidos e discutidos neste trabalho permitem as seguintes conclusoes:

1. O milho pode ser semeado após a ervilhaca, em plantio direto, sem restriçôes.

2. A soja apresentou desempenho satisfatório, em plantio direto, após as culturas de inverno estudadas (aveia, cevada e trigo).

3. As características químicas do solo estudadas, não foram afetadas pelos diferentes sistemas de produção avaliados .

4. A monocultura aumentou a intensidade das doenças do sistema radicular de trigo.

5. O trigo em rotação de culturas e em plantio direto, apresentou maior rendimento cultural e rentabilidade, em relação a este cereal em monocultura, bem como na comparação com as outras gramíneas de inverno.

6. O trigo em rotação de culturas e em plantio direto, evídenciou maior eficiência energetica, quando comparado aó seu emprego em monocultura e as outras gramíneas de inverno. 
7. A análise energética aliada à econômica, pode contribuir para a compreensão dos rendimentos culturais obtidos nos diferentes sistemas de produção. 


\section{REFERÊNCIAS BIBLIOGRÁFICAS}

ALMEIDA, F.S. Influência da cobertura morta do plantio direto na biologia do solo. In: FANCELLI, A.L.; TORRADO, P.V.; MACHADO, J., coord. Atualização em plantio direto. Campinas, Fundação Cargill, 1985. p. 104-44.

ALMEIDA, F.S. A alelopatia e as plantas. Londrina, IAPAR, 1988. 60p. (IAPAR. Circular, 53).

ALMEIDA, F.S. \& RODRIGUES, B.N. Guia de herbicidas; contribuição para o uso adequado em plantio direto e convencional. Londrina, IAPAR, 1985. $468 \mathrm{p}$.

ALMEIDA, F.S. ; RODRIGUES, B.N.; OLIVEIRA, V.F. Efeitos alelopáticos de extrato aguosos de palha de culturas de inverno. In: CONGRESSO BRASILEIRO DE HERBICIDAS E ERVAS DANINHAS, 15., Belo Horizonte, 1984. Resumos. Campinas, SBHED, 1984. p.9-10.

ANDERSON, W.P. Methods of weed control. In: Weed science; principles. 2.ed. Saint Paul, West Publ., 1983. p. 65-122. 
ANDIA, L.H. ; NEVES, M.F.; NEVES, E.M. Citricultura: cálculo do custo hora-máquina para conjuntos mecanizados, por operação agrícola. In: REUNIÃO PAULISTA DE INICIAÇÃO CIENTIFICA EM CIÊNCIAS AGRARIAS, 2. ; CONGRESSO DE INICIAÇÃO CIENTIFICA DA ESALQ, 6. , Piracicaba, 1991. Anais. Piracicaba, ESALQ, 1991. p.70.

BALDOCK, J.O.; HIGGS, R.L. ; PAULSON, W. H. ; JACKOBS, J.A. ; SHRADER, W. D. Legume and mineral $N$ effects on crop yields in several crop sequences in the upper Mississipi Walley. Agronomy Journal, Madison, 73(5): 885-90, 1981.

BARKER, M.R. \& WUNSCHE, W.R. Plantio direto in Rio Grande do Sul, Brasil. Outlook on Agricuture, Berkshine, 9(3): $\therefore 14-20,1977$.

BERARDI, G.M. Organic and conventional wheat production: examination of energy and economics. Agro-Ecosystems, Amsterdam, 4(3): 367-76, 1978 .

BLACK, A.L. Soil property changes associated with crop residue management in wheat-follow rotation. Soil Science Society of American Proceedings, Madison, 37(6): $943-6,1973$. 
BOUGLE, B.R. \& PEREIRA, L.R. Sistema de produção de trigosoja: informe preliminar sobre a evolução de algumas características do solo. In: REUNI ÃO ANUAL CONJUNTA DE PESQUISA DE TRIGO, 10., Porto Alegre, 1978. Solos e técnicas culturais, economia e sanidade. Passo Fundo, EMBRAPA/CNPT, 1978 . v.2, p. 31-9.

BRIGGLE, L.W. Introduction to energy use in wheat production. In: PIMENTEL, D., ed. Handbook of energy utilization in agriculture. Boca Raton, CRC Press, 1980. p. 109-16.

BRLULSEMA, T. $\boldsymbol{W}$. \& CHRISTIE, B.R. Nitrogen contribution to succeeding corn from alfafa and red clover. Agronomy Journal, Madison, 79(1): 96-100, 1987 .

BUKANTIS, R. \& GOODMAN, N. Energy inputs in barley production. In: PIMENTEL, D., ed. Handbook of energy utilization in agriculture. Boca Raton, CRC Press, 1980. p. 59-65. 
CASSOL, E.A. ; DHEIN, R.A. ; ELTZ, F. ; VIAU, L.V.M. ; COLOMBO, V. Efeitos do manejo do solo e de culturas sobre a erosão hídrica sob chuva natural em latossolo roxo. CTC, 1976 a 1984. In: COOPERATIVA REGIONAL TRITICOLA SERRANA LTDA. Resultados de experimentaçăo e pesquisa no CTC 1986-1986. I jui, 1987. p. 11-6.

CHRISTOFFOLETI, P.J. Controle de Brachiaria decumbens Stapf e de Cyperus rotundus L. em área com cana-deaçúcar (Saccharum spp) através da técnica de rotação com amendoim (Arachis hypogea L.) integrada ao uso de herbicidas. Piracicaba, 1988. 117p. (Mestrado - Escola Superior de Agricultura "Luiz de Queiroz"/USP).

DALE, J.E. \& CHANDLER, J.M. Herbicide-crop rotation for johnsongrass (Sorghum halepense) control. Weed Science, Champaign, 27(5): 479-85, 1979 .

DECHEN, S.C.F.; LOMBARDI NETO, F.; CASTRO, O.M. de. Gramineas e leguminosas e seus restos culturais no controle da erosão em Latossolo roxo. Revista Brasileira de Ciência do Solo, Campinas, 5(2): 133-7, 1981. 
DERPSCH, R. Adubação verde e rotação de culturaș. In: ENCONTRO NACIONAL DE PLANTiO DIRETO, 3. , Ponta Grossa, 1985. Anais. Castro, Fundação ABC, 1985. p.85-104.

DERPSCH, R. \& CALEGARI, A. Guia de plantas para adubaçao verde de inverno. Londrina, IAPAR, 1985. 96p. (IAPAR. Documentos, 9).

DERPSCH, R.; SIDIRAS, N.; HEINZMANN, F. Manejo do solo com coberturas verdes de inverno. Pesquisa Agropecuária Brasileira, Brasilia, 20(7): 761-73, 1985.

DERPSCH, R. ; ALBERINI, J.L. ; MONDARDO, A. ; MUZILLI, O. Informações sobre tremoço (Lupinus $\mathrm{sp}$ ). Informe de Pesquisa IAPAR, Londrina, 4(29): 1-20, 1980.

DIEHL, J.A. Doenças de raizes do trigo. Passo Fundo, EMBRAPA/CNPT, 1982. 15p. (EMBRAPA/CNPT. Circular Técnica, 3 ).

DIEHL, J.A. ; TINLINE, R.D. ; KOCHHANN, R. A. Perdas em trigo causada pela podridão comum de rázes no Rio Grande do Sul, 1979-81. Fitopatologia Brasileira, Brasilia, 8(3): $507-11,1983$ 
DIEHL, J.A.; OLIVEIRA, M.A.R. de; Igarashi, S. ; REIS, E.M. ; MEHTA, Y.R.; GOMES, L.S. Levantamento da ocorrência de doenças radiculares do trigo no Paraná. Fitopatologia Brasileira, Brasflia, $9(2): 179-88,1984$.

EMPRES $A$ BRASILEIRA DE PESQUISA $\Lambda G R O P E C U A R I A$. Serviço Nacional de Levantamento e Conservação de Solos. Levantamento de reconhecimento dos solos do estado do Paraná. Curitiba, EMBRAPA-SNLCS/SUDESUL-IAPAR, $1984 . \quad$ t. 1 . (EMBRAPA/SNLCS. Boletim de Pesquisa, 27).

FANCELLI, A.L. \& FAVARIN, J.L. O sistema de plantio direto. In: Encontro Paulista De Plantio Direto, $1 .$, Piracicaba, 1987. Plantio direto. Piracicaba, FEALQ, 1987. p. 11-7.

FEDERATION OF BRITISH PLANT PATHOLOGIST. Terminology SubComittee. A guide to the use of terms in plant 'pathology. Kew, Commeenwealth Mycological Institute, 1973. 55p. (Phytopathological Papers, 17).

FELIPPE JUNIOR, G. de; SOCOLOWSKI, J.C.; FANTI, O.D.J. Considerações sobre as tecnologias e a evolução da indústria de fertilizantes nitrogenados. In: SIMPósio SOBRE FERTILIZANTES NA AGRICULTURA BRASILEIRA, Brasilia, 1984. Anais. Brasilia, EMBRAPA-DEP, 1984. p.21-71. 
FERREIRA, A.C.M. Análise de alternativas de produção de culturas anuais em rotação com a cana-de-açúcar, na região de Ribeirão Preto, São Paulo. Viçosa, 1988. 127 . (D.S. - Universidade Federal de Vicosa).

GALLO, P.B.; LAVORENTI, A.; SAWAZAKI, E.; HIROCE, R.P.; MASCARENHAS, H. A. A. Efejto de cultivos anteriores de soja na produção e no teor de nitrogênio das folhas e dos grãos de milho. Revista Brasileira de Ciência do Solo, Campinas, 5(1): 64-7, 1981 .

GASSEN, D.N. Insetos associados à cultura do trigo no Brasil. Passo Fundo, EMBRAPA/CNPT, 1984. 39p. (EMBRAPA/ CNPT. Circular Técnica, 3 ).

GASSEN, D.N. Insetos associados à cultura do tremoço no Brasil. In: REUNĩ̃o BRASILEIRA DE TREMOÇO, 2., Passo Fundo, 1985. Anais. Passo Fundo, EMBRAPA/CNPT, 1986a. p. 63-76. (EMBRAPA/CNPT. Documentos, 10).

GASSEN, D.N. Parasitas, patógenos e predadores de insetos associados à cultura do trigo. Passo Fundo, EMBRAPA/ CNPT, 1986b. 86p. (EMBRAPA/CNPT. Circular Técnica, 1). 
GAUDENCIO, C.A. ; YORINORI, J.T.; GARCIA, A.; QUEIROZ, E.F. de. Rotação de culturas com a soja no norte do Estado do Paraná. Londrina, EMBRAPA/CNPSo, 1986. 10p. (EMBRAPA/CNPSo. Pesquisa em Andamento, 10).

HEICHEL, G.H. Assessing the fossil energy costs of propagating agricultural crops. In: PIMENTEL, D., ed. Handbook of energy utilization in agriculture. Boca Raton, CRC Press, 1980: p.27-33.

HERSTERMAN, O.B. ; SHEAFFER, C.C.; BARNES, D. K. ; LUESCHEN, K.E.; FORD, J.H. Alfafa dry matter and nitrogen production, and fertilizer nitrogen response in legumecorn rotations. Agronomy Journal, Madison, 78(1): 19$23,1986$.

INSTITUTO BRASILEIRO DE GEOGRAFIA E ESTATISTICA. Guarapuavis-PR. In: Enciclopedia dos municipios brasileiros. Rio de Janeiro, 1.959. v.31, p.234-8.

KALCKMANN, R.E. Práticas agronômicas na cultura do trigo no Brasil. Rio de Janeiro, EIGRA, 1970. 93p. (Estudos Técnicos, 41). 
KALCKMANN, R.E. \& OLIVEIRA, M.A. de. Resolverá a genética o atual impasse da triticultura brasileira? Pelotas, IAS, 1962. 11p. ( IAS. Comunicado, 21 ).

KATZNELSON, J. Studies in clover soil sickness I. The phenomenon of soil sickness in berseem and persian clover. Plant and Soil, Dordrecht, 36(2): 379-93, 1972.

KRONSTAD, W.E.; MCCUISTION, W.L. ; SWEARINGIN, M.L. ; QUALSET, C.O. Crop selection for specific residue management systems. In: OSCHWALD, W.R.; STELLY, M.; KRAL, D.M.; NAUSEEF, J.H. Crop residues management systems. Madison, ASA/CSSA/SSSA, 1978. cap. 12, p.20717. (ASA. Special Publication, 31 ).

LORENZI, H. Considerações sobre plantas daninhas no plantio direto. In: FUNDAÇÃO CARGILL. Plantio direto no Brasil. Campinas, 1984a. p.13-46.

LORENZI, H. Manual de identificação e controle de plantas daninhas; plantio direto e convencional. Nova Odessa, O Autor, 1984b. 220 p.

MARCOS FILHO, J. Produção de semente de soja. Campinas, Fundação Cargill, 1986. $86 \mathrm{p}$. 
a Y.RTIN, N.B.; SANTOS, Z.A.P.S.; ASSUMPÇÃO, R. Análise econômica da utilização da adubação verde nas culturas de algodão e soja em rotação com milho e amendoim. In: FUNDAÇÃO CARGILl. Adubação verde no Brasil. Campinas, 1984. p. 133-60.

.MASCARENHAS, H.A.A.; HIROCE, R.; BRAGA, N.R.; MIRANDA, M.A.C. de; BULISANI, E.A.; POMMER, C.V.; SAWAZAKI, E.; GALLO, P.B.; PEREIRA, J.C.V.A. Efeito do nitrogênio residual de soja na produção do milho. 2.ed. Campinas, IAC, 1986. 24p. (IAC. Boletim Técnico, 58).

MELlo, R. de. Análise energética de agroecossistemas: o caso de Santa Catarina, Florianópolis, 1986. 139p. (Mestrado - Universidade Federal de Santa Catarina).

MENGEL, K. \& KIRBY, E.A. Principles of plant nutrition. 4.ed. Bern, International Potash Institute, 1987. $687 p$.

MOTA, F.S. Clima e zoneamento para a triticultura no Brasil. In: OSORIO, E.A., coord. Trigo no Brasil. Campinas, Fundação Cargi11, 1982. v.1, p.27-61.

MUZILli, O. Manejo da fertilidade do solo. Manual Agropecuário para o Paraná, Londrina, 2: 45-61, 1978. 
MUZILLI, O. Princípios e perspectivas de expansão. In: FUNDAÇÃO INSTITUTO AGRONÔMICO DO PARANÁ. Plantio direto no Estado do Paraná. Londrina, 1981. p.11-7. (IAPAR. Circular, 23).

MUZILLI, O. Influência do sistema de plantio direto, comparando ao convencional sobre a fertilidade da camada arável do solo. Revista Brasileira de Ciência do Solo, Campinas, 7(1): 95-102, 1983.

$\therefore$ MUZILli, O. Fertilidade do solo em plantio direto. In: FANCELLI, A.L. ; TORRADO, P.V.; MACHADO, J. Atualização em plantio direto. Campinas, Fundação Cargill, 1985. p. $147-60$.

NEVES, E.M. \& SHIROTA, R. Consideraçðes sobre a importância, determinação e atualização dos custos agrícolas. Revista da ADEALQ, Piracicaba, (4): 62-9, 1986.

PATELla, J.F. Quinze anos de rotação com a cultura do trigo. Agros, Pelotas, 13(1): 13-26, 1978.

PATELLA, J.F. \& KALCKMANN, R.E. Resultados da rotação na cultura do trigo. Correio do Povo, Porto Alegre, 23 maio 1963. Suplemento Rural. 
PATRICK, Z.A.; TOUSSOUN, T.A.; KOCH, L.W. Effect of cropresidue decomposition products on plant roots. Annual Review of Phytopathology, Palo Alto, 2: 267-92, 1964.

PAVAN, M.A. Fertilidade do solo em plantio direto. In: ENCONTRO NACIONAL DE PLANTIO DIRETO, 3., Ponta Grossa, 1985. Anais. Castro, Fundação ABC, 1985. p.67-75.

PEREIRA, L.R. \& BOUGLE, B.R. Informe sobre o comportamento dos cultivos de inverno trigo e cevada em ensaios de rotaşão. In: REUNiño ANUAL CONJUNTA DE PESQUISA DE TRIGO, 8., Ponta Grossa, 1976. Solos e técnicas culturais. Passo Fundo, EMBRAPA/CNPT, 1976a. v.2, p.76-83.

PEREIRA, L.R. \& BOUGLE, B.R. Informe sobre o comportamento dos cultivos de verão soja, milho e sorgo em ensaios de rotação. In: REUNI ÃO CONJUNTA DE PESQUISA DE SOJA/RS/ SC, 4., Santa Maria, 1976. Resultados de pesquisa em soja obtidos no Centro Nacional de Pesquisa de Trigo em 1975/76. Passo Fundo, EMBRAPA/CNPT, 1976b. v.2, p.617 . 
PEREIRA, L.R. ; BOUGLÉ, B.R. ; LHAMBY, J.C. B. ; SANTOS, H.P. dos. Rotação de culturas. III. Efeito no rendimento de grãos do trigo. In: REUNIÃO NACIONAL DE PESQUISA DE TRIGO, 13. , Cruz Alta, 1984. Resultados de pesquisa do Centro Nacional de Pesquisa de Trigo. Passo Fundo, EMBRAPA/CNPT, 1984 . p. 170-9.

PEREIRA, L.R. ; SANTOS, H. P. dos; AMBROSI, I. ; REIS, E.M. ; VELLOSO, J.A.R.O. Efeitos da rotą̧ăo de culturas no rendimento do trigo. Passo Fundo, EMBRAPA/CNPT, 1985. 16p. (EMBRAPA/CNPT. Projeto, 004.80.004/7).

PIMENTEL, D. Energy inputs for the production, formulation, packaging, and transport of various pesticides. In : ., ed. Handbook of energy utilization in agriculture. Boca Raton, CRC Press, 1980a. p.45-8.

PIMENTEL, D., ed. Handbook of energy utilization in agriculture. Boca Raton, CRC Press, 1980b. 475p.

PIMENTEL, D. \& BURGESS, M. Energy inputs in corn production. In: PIMENTEL, D., ed. Handbook of energy utilization in agriculture. Boca Raton, CRC Press, 1980. p. $67-84$. 
PREW, R.D. ; BEANE, J.; CARTER, N.; CHUHCH, B.M.; DEWAR, A.M. ; LACEY, J.; PENNY, A. ; PlUMB, R.T.; THORNE, G. N. ; TODD, A.D. Some factors affecting the growth and yield of winter wheat grown as a third cereal with much or negligible take-all. The Journal of Agricultural Science, Cambridge, $107(3): 639-71,1986$.

REIS, E.M. Efeito da incorporação e do tipo de restos culturais de trigo na multiplicação de Helminthosporium satirum, no solo. Fitopatologia Brasileira, Brasilia, 8(3): $537-41, \quad 1984$

REIS, E.M. Doenças em plantio direto. Ocorrência e seu controle. In: ENCONTRO NACIONAL DE PLANTIO DIRETO, 3., Ponta Grossa, 1985. Anais. Castro, Fundação ABC, 1985a. p. 104-17.

REIS, E.M. Doenças do trigo I; podridão comum de raízes helmintosporiose. São Paulo, CNDA, 1985b. 20 p.

REIS, E.M. Doenças do trigo II; mal-do-pé. Passo Fundo, APASUL, $1986.29 \mathrm{p}$. 
REIS, E.M. \& ABRT̃O, J.J.R. Effect of tillage and wheat residue management on the vertical distribuition and inoculum of Coohliobolus sativus in soil. Plant Disease, Saint Paul, 67(10): 1088-9, 1983 .

REIS, E.M. \& AMBRosi, I. Efeito de rotação de culturas de inverno na densidade de inóculo de Helminthosporium sativum no solo, nas podridões radiculares e no rendimento do trigo. Fitopatologia Brasileira, Brasilia, $12(4): 365-8,1987$.

REIS, E.M. \& BAIER, A.C. Efeito do cultivo de alguns cereais de inverno na população de Helminthösporium sativum no solo. Fitopatologia Brasileira, Brasília, $8(2): 311-5,1983$.

REIS, E.M.; FERNANDES, J.M.C.; PICININI, E.C. Estratégia para o controle de doenças do trigo. Passo Fundo, EMBRAPA/CNPT, 1988. 50p. (EMBRAPA/CNPT. Documentos, 7 ).

REIS, E.M.; SANTOS, H.P. dos; LHAMBY, J.C.B. Rotação de culturas. I. Éfeitos sobre doenças radiculares do trigo nos anos 1981 e 1982. Fitopatologia Brasileira, Brasilia, 8(3): $431-7,1983$. 
REIS, E.M.; SANTOS, H.P. dos; PEREIRA, L.R. Rotação de culturas. IV. Efeito sobre o mosaico e doenças radiculares do trigo em 1983. Fitopatologia Brasileira, Brasilia, 10(3): $637-42,1985$.

REUNIÃO DE PESQUiSA DE SOJA DA REGIÃO SUL, 17., Porto Alegre, 1989 Recomendaçőes da Reunião de Pesquisa de soja da Região Sul. Porto Alegre, UFRGS, 1989. $85 p$.

RICE, E.L. Allelopathy. 2.ed. New York, Academic Press, 1984. $424 \mathrm{p}$.

ROSA, O.S. Rotação de culturas. In: SIMPÓSIO DE CONSERVAÇÃO DE SOLOS DO PLANALTO, 2., Passo Fundo, 1980. Anais. Passo Fundo, Universidade de Passo Fundo/Faculdade de Agronomia, 1980. p. 23-31.

¿SALOMÃO, C.C. Sistemas de plantio direto e convencional um enfoque de análise de decisão. Piracicaba, 1990. 127p. (Mestrado - Escola Superior de Agricultura "Luiz de Queiroz"/USP). 
SALVADORI, J.R. Relação entre insetos-pragas e manejo do solo. In: FERNANDES, J.M.; FERNANDEZ, M.R.; KOCHHANN, R.A.; SElles, F.; ZENTNER, R.P. Manual de manejo conservacionista do solo para os estados do Rio Grande do Sul, Santa Catarina e Paraná. Passo Fundo, EMBRAPA/ CNPT, 1991. p.43-52. (EMBRAPA/CNPT. Documentos, 1 ).

SANTOS, H.P. dos. Rotação de culturas e produtividade do trigo no Sul do Brasil. Piracicaba, ESALQ, 1990. 56p.

SANTOS, H.P. dos. Soja em sucessão a aveia branca, aveia preta, azevém e trigo: características agronômicas. Pesquisa Agropecuária Brasileira, Brasilia, 26(9): 15637 b , 1991 .

SANTOS, H.P. dos \& LHAMBY, J.C.B. Rotação de culturas em Guarapuava. XII. Efeitos de algumas culturas de inverno e de verão na evolução dos níveis de nutrientes e de matéria orgânica do solo, em plantio direto. In: REUNIÃo BRASILEIRA DE FERTILIDADE DO SOLO E NUTRIÇÃO DE PLANTAS, 20. Piracicaba, 1992. Anais. Piracicaba, SBCS, 1992. p. $114-5$. 
SANTOS, H.P. dos \& PEREIRA, L.R. Rotação de culturas. VII. Efeito de culturas de inverno sobre o rendimento de grãos e algumas características agronômicas das plantas de soja, no período de 1979 a 1985. Pesquisa Agropecuária Brasileira, Brasilia, 22(1): 163-70, 1987.

SANTOS, H.P dos \& PUTTKER, D. Rotą̧ão de culturas. XX. Efeito de leguminosas de inverno sobre o rendimento de grãos e sobre algumas características agronômicas do milho. Pesquisa Agropecuária Brasileira, Brasillia, 25(11): $1647-54,1990$.

SANTOS, H.P. dos \& REIS, E.M. Rotação de culturas. X. Efeito de culturas de inverno e de soja na evolução dos níveis de nutrientes e de matéria orgânica do solo. Revista Brasileira de Ciência do Solo, Campinas, 13(3): $295-302,1989$.

SANTOS, H.P. dos \& REIS, E.M. Rotação de culturas. XIX. Efeitos de culturas de inverno sobre o rendimento de grãos e sobre algumas características agronômicas da soja. Pesquisa Agropecuária Brasileira, Brasília, 25(11): 1637-45, 1990 . 
SANTOS, H.P dos \& REIS, E.M. Efeitos de culturas de inverno sobre o rendimento de grãos e sobre a estatura de plantas da soja. Pesquisa Agropecuária Brasileira, Brasilia, 26(5): 729-35, 1991 .

SANTOS, H.P. dos \& ROMAN, E.S. Rotação de culturas. XIV. Efeitos de culturas de inverno e de verão na disponibilidade de nutrientes e matéria orgânica do solo, no período agrícola de 1980 a 1986. Revista Brasileira de Ciência do Solo, Campinas, 13(3): 303-10, 1989.

SANTOS, H.P: dos \& SIQUEIRA, O.J.F. Rotação de culturas em Guarapuava. XI. Efeito de algumas culturas de inverno e de verão em algumas propriedades químicas do solo, num período de cinco anos, em plantio direto. In: REUNĨ̃o BRASILEIRA DE FERTILIDADE DO SOLO E NUTRIÇÃO DE PLANTAS, 20. , Piracicaba, 1992. Anais. Piracicaba, SBCS, 1992. p. $112-3$.

SANTOS, H.P. dos; PEREIRA, L.R.; REIS, E.M. Rotação de culturas. VIII. Efeito de sistemas de cultivo no rendimento de grãos do trigo. Pesquisa Agropecuária Brasileira, Brasilia, 23(3): 231-7, 1988 . 
SANTOS, H.P. dos; REIS, E.M.; PEREIRA, L.R. Rotaçåo de culturas. Xxil. Efeitos no rendimento de graos e nas doenças do sistema radicular do trigo e, de outras culturas de inverno e de verão, num período de 9 anos. In: REUNião CENTRO SUL DE ADUBAÇÃO VERDE E ROTAÇÃO DE CULTURAS, 2., Londrina, 1989. Rotação de culturas; resultados de pesquisa 1988. Passo Fundo, EMBRAPA/CNPT, 1989a. p. 10-8.

SANTOS, H.P. dos; REIS, E.M. ; PEREIRA, L.R. Rotação de culturas. XVII. Efeitos no rendimento de grãos e nas doenças do sistema radicular do trigo de 1980 a 1987. Pesquisa Agropecuária Brasileira, Brasillia, 25(11): $1627-35,1990 a$.

SANTOS, H.P dos; REIS, E.M. ; PEREIRA, L.R. Rotação de culturas. XVIII. Influência de sistemas de rotação de culturas no rendimento e na intensidade de doenças do sistema radicular do trigo. Pesquisa Agropecuária Brasileira, Brasilia, 25(8): 1201-7, 1990b.

SANTOS, H.P. dos; REIS, E.M. ; PÜTTKER, D. Culturas de inverno para plantio direto no Sul do Brasil. Passo Fundo, EMBRAPA/CNPT, 1990c. 24p. (EMBRAPA/CNPT. Circular Técnica, 3). 
SANTOS, H.P. dos; REIS, E.M.; WOBETO, C. Rotação de culturas em Guarapuava. IX. Efeitos no rendimento de grãos e nas doenças do sistema radicular da cevada, em plantio direto de 1984 a 1986. Pesquisa Agropecuária Brasileira, Brasília, 26(6): 901-6, 199 la.

SANTOS, H.P. dos; WOBETO, C.; PEREIRA, L.R. Rotação de culturas em Guarapuava. X. Efeitos das culturas de inverno em plantio direto sobre caracteristicas agronômicas da soja. Pesquisa Agropecuária Brasileira, Brasilia, 26(9): 1551-61, $1991 \mathrm{~b}$.

SANTOS, H.P. dos; PEREIRA, L.R. ; LHAMBY, J.C.B. ; REIS, E.M. Rotação de culturas. VI. Avaliação do rendimento de grãos de trigo observando-se um intervalo de dois anos de rotação. Pesquisa Agropecuária Brasileira, Brasil ia, $21(10): 1067-72,1986$.

SANTOS, H.P. dos; REIS, E.M. ; PEREIRA, L.R. ; VIEIRA, S.A. Efeito da rotação de culturas no rendimento de grãos e na ocorrência de doenças radiculares de trigo (Triticum aestivum) e de ouiras culturas de inverno e de verão, de 1979 a 1986. Passo undo, EMBRAPA/CNPT, 1987a. 38p. (EMBRAPA/CNPT. Documentos, 7 ). 
SANTOS, H.P. dos; REIS, E.M.; PEREIRA, L.R.; VIEIRA, S.A. Rotação de culturas. XII. Avaliação do rendimento de grãos de trigo e de doenças radiculares, observando-se um intervalo de dois anos de rotação e de outras culturas de inverno e de soja de 1979 a 1986. In: REUNIÃO DE PESQUISA DE SOJA DA REGIÃo SUL, 15., Cruz Alta, 1987. Soja; resultados de pesquisa 1986-1987. Passo Fundo, EMBRAPA/CNPT, $1987 \mathrm{~b}$. p. 75-89.

SANTOS, H.P. dos; REIS, E.M.; PEREIRA, L.R.; VIEIRA, S.A. Rotaçao de culturas. XIII. Efeito no rendimento de grãos e de doenças radiculares do trigo e de outras culturas de inverno e de verão de 1980 a 1986. In: REUNIÃO DE PESQUISA DE SOJA DA REGIÃO SUL, 15., Cruz Alta, 1987. Soja; resultados de pesquisa 1986-1987. Passo Fundo, EMBRAPA/CNPT, 1987c. p.90-104.

SANTOS, H.P. dos; REIS, E.M.; VIEIRA, S.A.; PEREIRA, L.R. Rotação de culturas e produtividade do trigo no RS. Passo Fundo, EMBRAPA/CNPT, 1987d. 32p. (EMBRAPA/CNPT. Documentos, 8 ). 
SANTOS, H.P. dos; REIS, E.M. ; WOBETO, C.; PEREIRA, L.R. Rotação de culturas em Guarapuava. VIII. Efeitos no rendimento de grãos, nas doenças do sistema radicular do trigo e, de outras culturas de inverno e de verão, num período de 5 anos, em plantio direto. In: REUNIAO CENTRO-SUl DE adubaÇaO VERDE E ROTAÇÃo DE CUlturas, 2., Londrina, 1989. Rotação de culturas; resultados de pesquisa 1988. Passo Fundo, EMBRAPA/CNPT, 1989b. p.2530 .

SANTOS, H.P. dos; VIEIRA, S.A.; PEREIRA, L.R.; ROMAN, E.S. Rotação de culturas. XVI. Efeitos de sistemas de cultivo no rendimento de grãos e outras caracteristicas agronômicas das plantas de soja. Pesquisa Agropecuária Brasileira, Brasília, 26(9): 1539-49, $1991 \mathrm{c}$.

SANTOS, H.P. dos; WOBETO, C.; PEREIRA, L.R.; REIS, E.M. Rotação de culturas em Guarapuava. IV. Rendimentos de grãos do trigo e de outras culturas de inverno e de verão em semeadura direta de 1984 a 1986. In: REUNI $\widetilde{O}$ DE ROTAÇÃo DE CUlturas, 1., Ponta Grossa, 1987. Rotação de culturas; resultados de pesquisa 1986. Passo Fundo, EMBRAPA/CNPT, 1987 e. p. 48-58. 
SANTOS, H.P. dos; WOBETO, C.; PEREIRA, L.R.; REIS, E.M.; PRESTES, A.M. Rotação de culturas em Guarapuava. III. Rendimento de grãos da cevada e de outras culturas de inverno e de verão, em semeadura direta de 1984 a 1986. In: REUni Ão DE ROTAÇÃO DE CUlTuRAS, 1., Ponta Grossa, 1987. Rotação de culturas; resultados de pesquisa 1986. Passo Fundo, EMBRAPA/CNPT, $1987 \mathrm{f}$. p. 35-47.

SANTOS, H.P. dos; REIS, E.M.; LHAMBY, J.C.B.; PEREIRA, L.R. ; ROMAN, E.S.; SALVADORI, J.R. Efeito do manejo do solo e de sistemas de cultivo sobre a produçăo de trigo. Passo Fundo, EMBRAPA/CNPT, 1990d. 15p. (EMBRAPA/CNPT. Projeto, $004.86 .008 / 6)$.

SCOTT, W.O. \& KRUMMEL, J. Energy used in producing soybeans. In: PIMENTEL, D., ed. Handbook of energy utilization in agriculture. Boca Raton, CRC Press, 1980. p. 117-21.

SCHERER, E.E. O tremoço e seu cultivo no Estado de Santa Catarina. Florianópolis, EMPASC, 1982. 20p. (EMPASC. Boletim Técnico, 14). 
SELMAN, M. Experiments in continuous wheat. Part I. The effect of break crops introduced into a run of continuous wheat (Sykes Field). Experimental Husbandry, London, (29): 1-7, 1975 .

SHANER, G. Effect of environment on fungal leaf blights of small grains. Annual Review of Phytopathology, Palo Alto, 19: 273-96, 1981 .

SHRADER, W.D. ; PESEK, J.; SCHALLER, F.W. Crop rotations. Facts and fiction. Iowa Farm Science, Ames, 16: 6-9, 1962.

SIDIRAS, N. \& PAVAN, M.A. Influência do sistema de manejo de solo no seu nivel de fertilidade. Revista Brasileira de Ciência do Solo, Campinas, 9(3): 249-54, 1985.

SIDIRAS, N.; VIEIRA, S.R. ; ROTH, C.H. Determinação de algumas caracteristicas físicas de um Latossolo Roxo Distrófico sob plantio direto e preparo convencional. Revista Brasileira de Ciência do Solo, Campinas, 8(3): $265-8,1984$ 
SLOPE, D.B. \& ETHERIDGE, J. Grain yield and incidence of take-all (Ophiobolus graminis Sacc.) in wheat grown in different crop sequences. Annals of Applied Biology, Cambridge, 67(1): 13-22, 1971 .

SUTHERLAND, W.N.; SHRADER, W.D.; PESEK, J.T. Efficiency of legume residue nitrogem and inorganic nitrogem in corn production. Agronomy Journal, Madison, 53(5): 339-42, 1961.

TEDESCO, M.J.; VOLKWEISS, S.J.; BOHNEN, H. Análise de solos, plantas e outros materiais. Porto Alegre, UFRGS/ Departamento de solos, 1985. 32p. (UFRGS. Boletim Técnico, 5).

TOMASINI, R.G.A. Diversificação de culturas de inverno na região triticola do Sul do Brasil. 2.ed. Passo Fundo, EMBRAPA/CNPT, 1987. 54p. (EMBRAPA/CNPT. Documentos, $5)$.

TRINANES SCHAFFNER, E. \& URIARTE BREGANTE, C. Efecto residual de rastrojos de girasol, maiz, soja y sorgo en el crescimiento y produccion de trigo. Montevideo, 1984. 196p. (Graduaccion - Faculdad de Agronomia/Universidad de la Republica). 
VIEGAS, G.P. \& MACHADO, D.A. Rotação de culturas uma prática lucrativa. São Paulo, Sementes Cargill Ltda, 1990. $28 \mathrm{p}$.

VIEIRA, M.J. Perdas por erosão sob diferentes sistemas de preparo do solo para a cultura da soja (Glycine max (L) Merr) em condições de chuva simulada. Porto Alegre, 1977. 108p. (Mestrado - Faculdade de Agronomia/UFRGS).

VIEIRA, M.J. Propriedades físicas clo solo. In: FUNDAÇ̃̃O INSTITUTO AGRONÔMICO DO PARANÁ. Plantio direto no Estado do Paraná. Londrina, IAPAR, 1981. p. 19-32. (IAPAR. Circular, 23).

VIEIRA, M.J. Comportamento físico do solo em plantio direto. In: FANCELLI, A.L.; TORRADO, P.V. ; MACHADO, J., coord. Atualização em plantio direto. Campinas, Fundação Cargill, 1985. p.163-79.

WALKER, R.H. \& BUCHANAN, G.A. Crop manipulation in integrated weed mangement systems. Weed Science, Champaign, 30(suppl. 1): 1-11, 1982 .

WEAVER, S.H. Energy use in the production of oats. In: PIMENTEL, D., ed. Handbook of energy utilization in agriculture. Boca Raton, CRC Press, 1980. p.85-92. 
WIETHULter, S. Pousio e lavra profunda e seu efeito na ocorrência de mal-do-pé em trigo. Passo Fundo, s.ed., 1978. $13 \mathrm{p}$

WISCHMEIER, W.H. Cropping-management factor evaluations for a universal soil-loss equation. Soil Science Society of America Proceedings, Madison, 24: 322-6, 1960.

WUNSCHE, W.A. \& DENARDIN, J.E. Perdas de solo e escorrimento de água sob chuva natural em Latossolo Vermelho Escuro nas culturas de trigo e soja. In: ENCONTRO NACIONAL DE PESQUISA SOBRE CONSERVAÇÃO DO SOLO, 2., Passo Fundo, 1978. Anais. Passo Fundo, EMBRAPA/CNPT, 1978. p. 289-96

ZENTNER, R.P.; SELLES, F.; SANTOS, H.P. dos; AMBROSI, I . Effect of crop rotations on yields, soil characteristics, and economic returns in Southern Brazil. In: INTERNATIONAL WORKSHOP ON CONSERVATION TILLAGE SYSTEMS, Passo Fundo, 1990. Conservation tillage for subtropical areas; proceedings. Passo Fundo, CIDA/EMBRAPA/ CNPT, 1990. p. 96-116. 
APÊNDICE 
TABELA 1. Principais caracteristicas agronômicas dos cultivares de milho, de soja e de trigo, utilizadas no sistema de produção para trigo, no período de 1990 e 1991, em plantio direto.

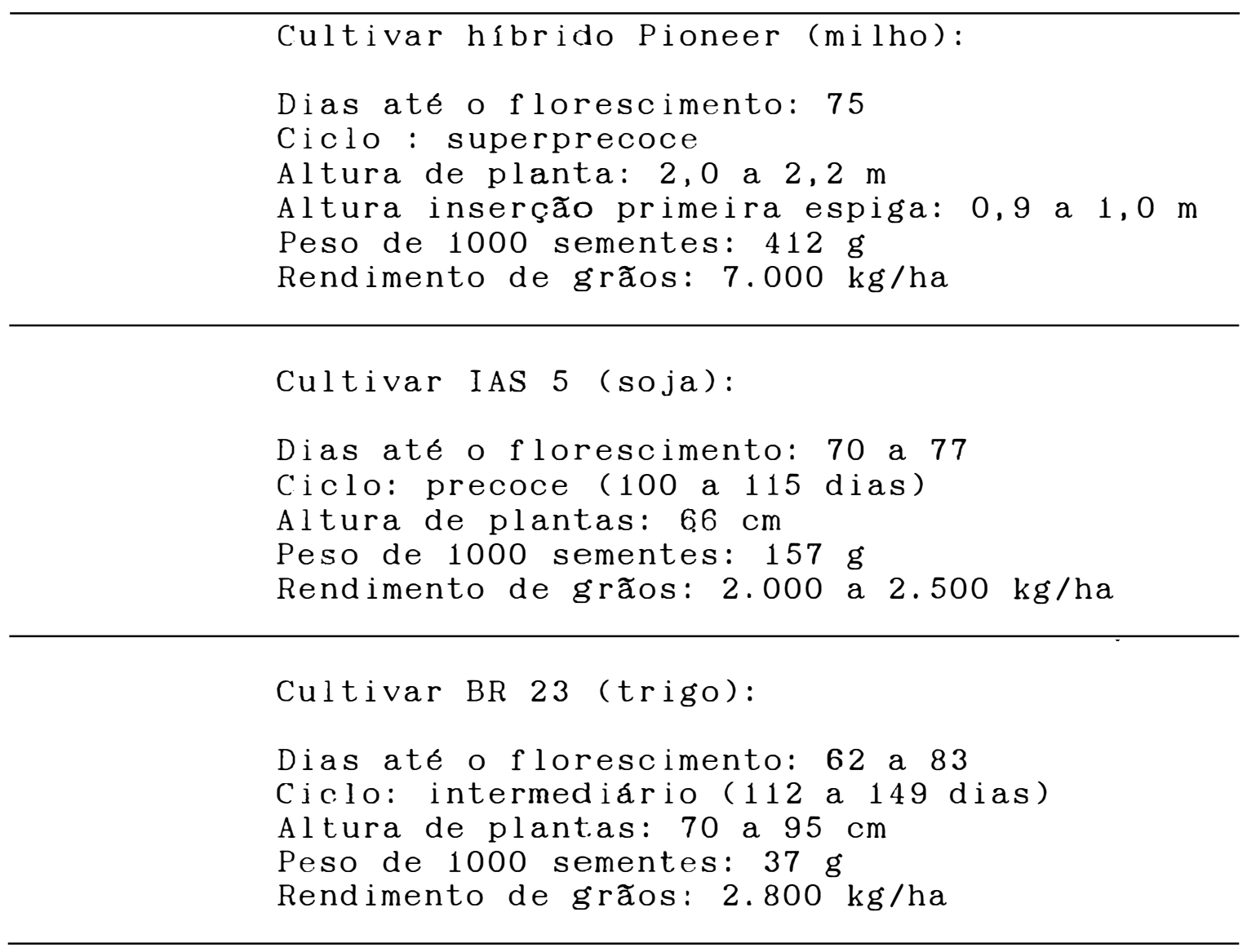


TABELA 2. Coeficientes técnicos e energéticos, por hectare, de aveia de 1990 e 1991, em plantio direto.

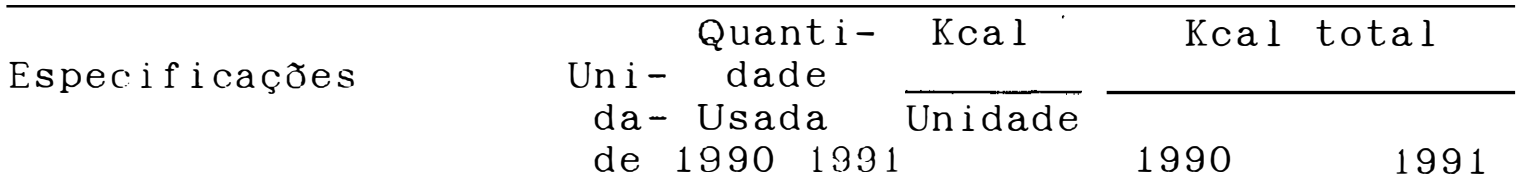

Insumos:

Semente

Adubação manutenção cobertura

Fungicida Propiconazole Triadimenol

Herbicida Diuron +

Paraquat

Glifosate

Bentazon

Paraquat

Inseticida Triclorfom

Carbaril

Dif 1 ubenzurom

$$
\text { k }
$$

$\begin{array}{rrrrrr}\mathrm{kg} & 88 & 80 & 4.108 & 361.504 & 328.640 \\ \mathrm{~kg} & 180 & 130 & 2.805 & 504.900 & 364.650 \\ \mathrm{~kg} & 20 & 30 & 6.917 & 138.340 & 207.510 \\ \mathrm{l} & 0,5 & 0,5 & 64.910 & 8.114 & 8.114 \\ \mathrm{~g} & - & 235 & 51.600 & - & 2.064\end{array}$

$12,5-99.910$

$1 \quad-2,062.770$

$11,5-62.770$

$12,5-62.770$

$12,0-86.910$

g $\quad-60061.470$

74.933

45. $19 \overline{4}$

31.385

86.910

31.350
$-\quad 3.688$

Semeadura:

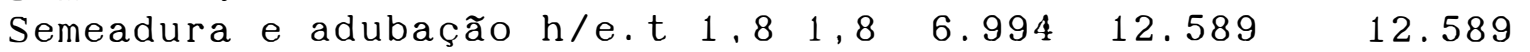

Tratos culturais:

Aplicação cobertura

Aplicação fungicida

fungicida

Apl i cação herbicida

h/e.t $1,51,5$

2.356

2. 356

3. 534

3.534

h/e.t $1,51,5$

500

3.534

3.534

$\mathrm{h} / \mathrm{H}-\mathrm{O}, 3$

2. 356

10. $60 \overline{2}$

150

h/e.t $4,51,5$

2. 356

3. 534

3.534

7. 068

Colheita:

Colheita merânira $\quad$ h/col. $1,0 \quad 187.131 \quad 187.131 \quad 1837.131$

Total kical 1.472 .2041 .223 .765

\begin{tabular}{|c|c|c|}
\hline $\begin{array}{l}\text { Abreviaturas: } \\
\text { h/e.t } \\
\text { h/H } \\
\text { h/col } \\
\mathrm{PC}\end{array}$ & & $\begin{array}{l}\text { Significados: } \\
\text { hora de equipamento com trator } \\
\text { hora de trabalho humano } \\
\text { hora de trabalho com colhedeira } \\
\text { produtividade cultural }\end{array}$ \\
\hline $\begin{array}{l}\text { Aveia } 1=\text { PC: } \\
\text { Aveia } 2=\text { PC: } \\
\text { Aveia } 3=\text { PC: }\end{array}$ & $\begin{array}{ll}1990: & 1991: \\
1,836 & 2,641 \\
1,983 & 2,204 \\
1,955 & 2,508\end{array}$ & $\begin{array}{l}\mathrm{kg} / \mathrm{Mcal} \\
\mathrm{kg} / \mathrm{Mcal} \\
\mathrm{kg} / \mathrm{Mcal} l\end{array}$ \\
\hline
\end{tabular}


TABELA 3. Coeficientes técnicos e energéticos, por hectare, de cevada de 1990 e 1991, em plantio direto.

\begin{tabular}{|c|c|c|c|c|c|c|}
\hline \multirow[t]{2}{*}{ Especificacões } & \multirow{2}{*}{$\begin{array}{c}\text { Un i- } \\
\mathrm{da}^{-} \\
\mathrm{de}\end{array}$} & \multirow{2}{*}{\multicolumn{2}{|c|}{$\begin{array}{l}\text { Quanti- } \\
\text { dade } \\
\text { Usada }\end{array}$}} & \multirow{2}{*}{$\frac{\text { Kcal }}{\text { Unidade }}$} & \multicolumn{2}{|c|}{ Kcal total } \\
\hline & & & 1991 & & 1990 & 1991 \\
\hline \multicolumn{7}{|l|}{ Insumos: } \\
\hline Semente & $\operatorname{lig}$ & 120 & 100 & 3.318 & 398.160 & 331.800 \\
\hline \multirow{2}{*}{$\begin{aligned} \text { Adubação } & \text { manutenç } \widetilde{a} o \\
& \text { cobertura }\end{aligned}$} & $\mathrm{kg}$ & 234 & 220 & 2.805 & 656.370 & 617.100 \\
\hline & lig & 30 & 20 & 6.917 & 207.510 & 138.340 \\
\hline Fungicida Fropiconazole & 1 & 0,5 & 0,5 & 64.910 & 8.114 & 8.114 \\
\hline Triad imenol & $g$ & 235 & 235 & 51.600 & 2.064 & 2.064 \\
\hline \multicolumn{7}{|l|}{ Herbicida Diuron +} \\
\hline Paraquat & l & 2,5 & - & 99.910 & 74.933 & - \\
\hline Gl ifosate & 1 & - & 2,0 & 62.770 & - & 60.259 \\
\hline Bentazon & 1 & 1,5 & - & 62.770 & $45 \cdot 194$ & - \\
\hline Inseticida Triclorfom & 1 & 2,0 & - & 86.910 & 86.910 & - \\
\hline Dif lubenzurom & $\mathrm{m} g$ & - & 60 & 61.470 & - & 3.688 \\
\hline
\end{tabular}

Semeadura:

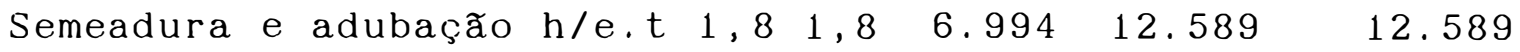

Tratos culturais:

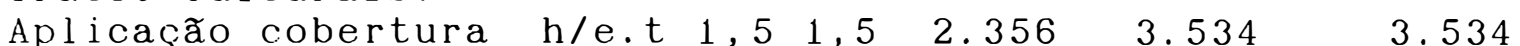

Aplicação fungicida h/e.t $1,5 \quad 1,5 \quad 2.356 \quad 3.534 \quad 3.534$

$\begin{array}{rlllrrr}\text { fungicida } & \text { h/H } & 0,3 & 0,3 & 500 & 150 & 150 \\ \text { Aplicação herbicida } & \text { h/e.t } & 3,0 & 1,5 & 2.356 & 7.068 & 3.534\end{array}$

Aplicação inseticida h/e.t $1,5 \quad 1,5 \quad 2.356 \quad 3.534 \quad 3.534$

Colheita:

Colheita mecânica h/col. $\quad 1,0 \quad 187.131 \quad 187.131 \quad 187.131$

\begin{tabular}{lc}
\hline Total Kcal & \\
\hline Abreviaturas: & Significados: \\
h/e.t & hora de equipamento com trator \\
h/H & hora de trabalho humano \\
h/col. & hora de trabalho com colhedeira \\
PC & produtividade cultural
\end{tabular}

\begin{tabular}{lll}
$1990:$ & $1991:$ \\
Cevada $=$ PC: & 1,422 & $2,862 \mathrm{~kg} /$ Mcal \\
\hline
\end{tabular}


TABELA 4. Coeficientes técnicos e energéticos, por hectare, de milho de 1990 e 1991, em plantio direto.

\begin{tabular}{|c|c|c|c|c|}
\hline \multirow{2}{*}{ Espec if icaços } & \multirow{2}{*}{$\begin{array}{l}\text { Quanti- } \\
\text { Uni- dade } \\
\text { da- Usada } \\
\text { de } 1990 \quad 139\end{array}$} & \multirow{2}{*}{$\frac{\text { Kcal }}{\text { Unidade }}$} & \multicolumn{2}{|c|}{ Kcal total } \\
\hline & & & 1990 & 1991 \\
\hline
\end{tabular}

Insumos:

$\begin{array}{crrrrrr}\text { Semente ervilhaca } & \mathrm{kg} & 40 & 55 & 7.584 & 303.360 & 417.120 \\ \text { milho } & \mathrm{kg} & 20 & 20 & 24.806 & 496.120 & 496.120 \\ \text { Adubaça manutenção } & \mathrm{kg} & 300 & 290 & 2.805 & 841.500 & 813.450 \\ \text { Herbicida Diuron t } & & & & & & \\ \text { Paraquat } & 1 & 2,5 & 1,5 & 99.910 & 74.933 & 44.984 \\ \text { Glifosate } & 1 & - & 2,0 & 62.770 & - & 60.259 \\ \text { Gesatop 800 } & 1 & 7,0 & - & 62.770 & 219.695 & - \\ \text { Inseticida Carbaril } & \mathrm{g} & - & 600 & 61.770 & - & 31.350\end{array}$

Semeadura:

Semeadura e adubação h/e.t $3,6 \quad 3,6 \quad 6.994 \quad 25.178 \quad 25.178$

Tratos culturais:

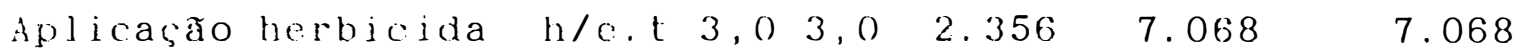

Aplicação inseticida h/e.t $\quad-\quad 1,5 \quad 2.356 \quad-\quad 3.534$

Colheita:

Colheita mecânica $\quad$ h/col. $\quad 1,5 \quad 187.131280 .697 \quad 280.697$

\begin{tabular}{lll}
\hline Total Kcal & 2.248 .5512 .179 .760
\end{tabular}

\begin{tabular}{ll}
\hline Abreviaturas: & Significados: \\
h/e.t & hora de equipamento com trator \\
h/H & hora de trabalho humano \\
h/col. & hora de trabalho com colhedeira \\
PC & produtividade cultural
\end{tabular}

Milho $1=\mathrm{PC}: \begin{array}{lll}1990: & 1991: \\ & 1,440 & 3,745 \mathrm{~kg} / \mathrm{Mcal}\end{array}$

Milho $2=\mathrm{PC}: 1,5193,721 \mathrm{~kg} / \mathrm{Mcal}$ 
TABELA 5. Coeficientes técnicos e energéticos, por hectare, de soja de 1990 e 1991, em plantio direto.

\begin{tabular}{|c|c|c|c|c|}
\hline \multirow{2}{*}{ Especificações } & \multirow{2}{*}{$\begin{array}{l}\text { Quanti- } \\
\text { Uni- dade } \\
\text { da- Usadal } \\
\text { de } 19901991\end{array}$} & \multirow{2}{*}{$\frac{\text { Kcal }}{\text { Unidade }}$} & \multicolumn{2}{|c|}{ Kcal total } \\
\hline & & & 1990 & 1991 \\
\hline
\end{tabular}

Insumos :

Semente

Adubação manutenção

Fungicida Thiabendazol

$\begin{array}{lllll}\mathrm{kg} & 90 & 90 & 7.584 & 682.560\end{array}$

682.560

$\begin{array}{lllll}\mathrm{kg} & 250 & 250 & 1.355 & 338.750\end{array}$

338.750

Herbicida Diuron +

Paraquat

g 200

$-51.600$

1.032

Fluaz if ob-P-

But i l

Paraquat

$1 \quad-2,599.910$

$-\quad 74.933$

$11,21,599.910$

$12,5-62.770$

9. 991

12.489

Inseticida Clorpirifós

11,0

- 86.910

31.385

41.717

Semeadura:

Semeadura e adubação h/e.t $1,8 \quad 1,8 \quad 6.994 \quad 12.589$

12.589

Tratos culturais:

Aplicaço fungicida

Aplicaça he roicida

$\begin{array}{llll}\mathrm{h} / \mathrm{ll} & 0,3, & - \\ \mathrm{h} / \mathrm{e} . \mathrm{t} & 3,0 & 3,0\end{array}$

500

2. 356

h/e.t $1,5-2.356$

150
7.068
3.534

$7.06 \overline{8}$

Aplicação inseticida

\begin{tabular}{llllll} 
Colheita mecânica & h/col. & 1,0 & 187.131 & 187.131 & 187.131 \\
\hline
\end{tabular}

$\begin{array}{llllll}\text { Colheita mecânica } \quad \mathrm{h} / \mathrm{col} . & 1,0 & 187.131 & 187.131 & 187.131\end{array}$

\begin{tabular}{llllll} 
Colheita mecânica $\quad$ h/col. & 1,0 & 187.131 & 187.131 & 187.131 \\
\hline
\end{tabular}

Colheita:

Total Kcal

1.315 .9071 .315 .520

\begin{tabular}{ll}
\hline Abreviaturas: & Significados: \\
h/e.t & hora de equipamento com trator \\
h/H & hora de trabalho humano \\
h/col & hora de trabalho com colhedeira \\
PC & produtividade cultural
\end{tabular}

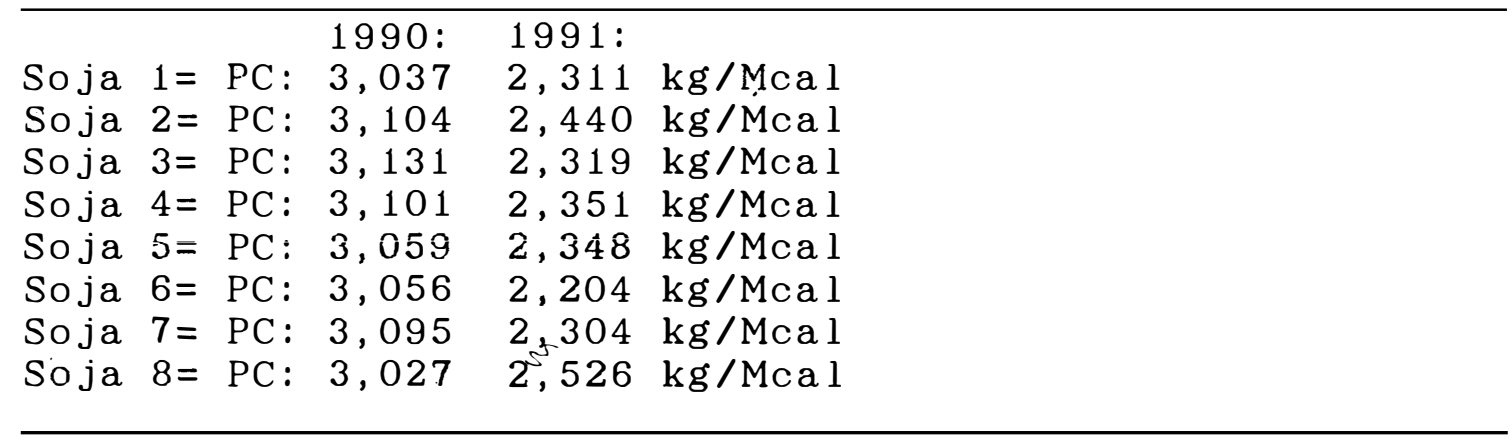


TABELA 6. Coeficientes técnicos e energéticos, por hectare, de trigo de 1990 e 1991, em plantio direto.

\begin{tabular}{|c|c|c|c|c|}
\hline \multirow{2}{*}{ Espec if icaçð̄es } & \multirow{2}{*}{$\begin{array}{l}\text { Quanti- } \\
\text { Uni- } \text { dade } \\
\text { da- Usada } \\
\text { de } 19901991\end{array}$} & Kcal & \multicolumn{2}{|c|}{ Kcal total } \\
\hline & & Unidade & 1990 & 1991 \\
\hline
\end{tabular}

Insumos :

Semente

Adubação manutenção

kg $\quad 110 \quad 110$

$3.002 \quad 330.220$

330.220

cobertura

kg $234 \quad 210$

$2.805 \quad 656.370$

$589: 050$

Fungicida Propiconazole

$\begin{array}{lll}\mathrm{kg} & 30 & 30\end{array}$

6.917207 .510

207.510

Triadimenol

10,5

$-64.910$

g 23523551.600

8. 114

Terbuconazole

1

$-0,7$

64.910

2.064

2. 064

Herbicida Diuron +

Paraquat

Glifosate

Bentazon

$\begin{array}{rrrr}1 & 2,5 & - & 99.910 \\ 1 & - & 2,0 & 62.770 \\ 1 & 1,5 & - & 62.770 \\ 1 & 2,0 & - & 86.910 \\ g & - & 60 & 61.470\end{array}$

74.933

12.138

Inseticida Triclorfom

Dif lubenzurom

Semeadura:

Semeadura e adubação h/e.t 1,8 1,8

$6.994 \quad 12.589$

12.589

Tratos culturais:

Aplicação cobertura

Aplicação fungicida

h/e.t $1,51,5$

h/e.t $1,51,5$

2. 356

2. 356

3.534

3.534 fungi cida

$\mathrm{h} / \mathrm{H} \quad 0,3 \quad 0,3$

500

3. 534

150

3.534

150

Aplicaçăo herbicida h/e.t $3,01,5$

2.356

7.068

3.534

Aplicação inseticida

2.356

3.534

3.534

Colheita:

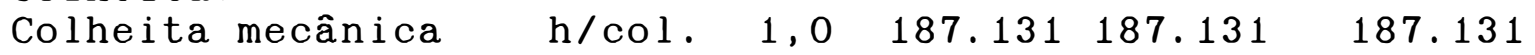

Total Kcal

1.628 .8551 .418 .935

Abreviaturas:
h/e.t
h/H
h/col.
PC

Significados:

hora de equipamento com trator

hora de trabalho humano

hora de trabalho com colhedeira produtividade cultural

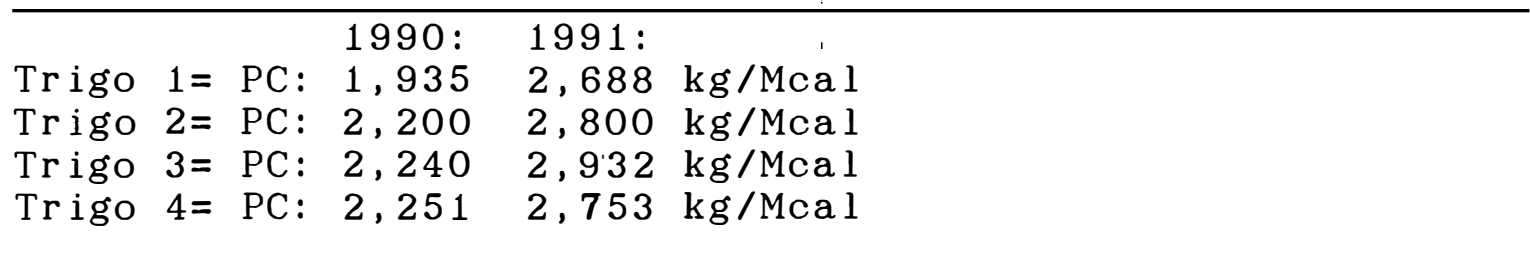

